\title{
ANÁLISE DA CADEIA PRODUTIVA E ESTRUTURA DE CUSTOS DO SETOR BRASILEIRO DE PRODUTOS RESINOSOS
}

\author{
JOSÉ PINTO DA ROCHA JORGE FERREIRA
}

Dissertação apresentada à Escola Superior de Agricultura "Luiz de Queiroz", Universidade de São Paulo, para a obtenção de título de Mestre em Ciências, Área de Concentração: Economia Aplicada.

\author{
PIRACICABA \\ Estado de São Paulo - Brasil \\ Dezembro - 2001
}




\title{
ANÁLISE DA CADEIA PRODUTIVA E ESTRUTURA DE CUSTOS DO SETOR BRASILEIRO DE PRODUTOS RESINOSOS
}

\author{
JOSÉ PINTO DA ROCHA JORGE FERREIRA
}

Engenheiro Florestal

Orientador: Prof. Dr. LUIZ CARLOS ESTRAVIZ RODRIGUEZ

Dissertação apresentada à Escola Superior de Agricultura "Luiz de Queiroz", Universidade de São Paulo, para a obtenção de título de Mestre em Ciências, Área de Concentração: Economia Aplicada.

\author{
PIRACICABA \\ Estado de São Paulo - Brasil \\ Dezembro - 2001
}


Dados Internacionais de Catalogação na Publicação (CIP) DIVISÃO DE BIBLIOTECA E DOCUMENTAÇÃO - ESALQ/USP

\section{Ferreira, José Pinto da Rocha Jorge}

Análise da cadeia produtiva e estrutura de custos do setor brasileiro de produtos resinosos / José Pinto da Rocha Jorge Ferreira. - - Piracicaba, 2002. $105 \mathrm{p}$.

Dissertação (mestrado) - - Escola Superior de Agricultura Luiz de Queiroz, 2002.

Bibliografia.

1. Economia de custos de transação 2. Gomas e resinas 3. Indústria florestal 4. Produção em cadeia 5. Produtos florestais 6. Recursos florestais I. Título

CDD 634.98

\section{"Permitida a cópia total ou parcial deste documento, desde que citada a fonte - $\mathrm{O}$ autor"}




\section{AGRADECIMENTOS}

Agradeço ao meu orientador, o professor doutor Luiz Carlos Estraviz Rodrigues, pela orientação e amizade. E também aos professores doutores Zilda Paes de Barros Mattos, José Otávio Brito, Miriam Rumenos Piedade Bacchi, Carlos José Caetano Bacha, Joaquim Bento de Souza Ferreira Filho e Geraldo Sant'Ana de Camargo Barros que contribuíram de maneira relevante para a elaboração deste trabalho. A todos os amigos que encontrei neste mestrado e, em especial, aos amigos da república "Deus Quis" quero também deixar uma palavra de reconhecimento.

Agradeço igualmente à Associação dos Resinadores do Brasil por disponibilizar dados e informações indispensáveis ao trabalho. Aos produtores florestais, comerciantes e industriais ligados ao setor e a todas as empresas que, direta e indiretamente, deram o seu contributo, respondendo aos questionários e esclarecendo dúvidas em entrevistas. Em particular, aos diretores da empresa Resinas Tropicais Indústria e Comércio Ltda., com especial ênfase no Dr. Carlos Alberto Gomes Pereira, grande motivador da pesquisa e meu tutor nos primeiros tempos de Brasil.

Agradeço de forma especial à minha família pela ajuda e incentivo em todo este período longe de Portugal, e à Viviane, minha mulher e grande apoio nas ultimas etapas da realização deste mestrado. 


\section{SUMÁRIO}

Página

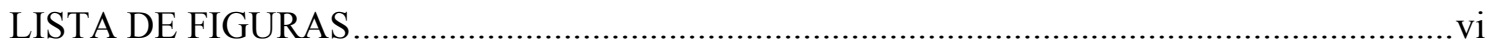

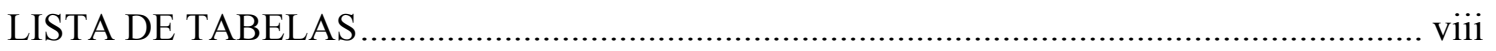

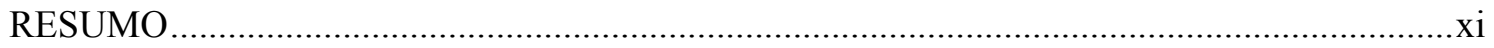

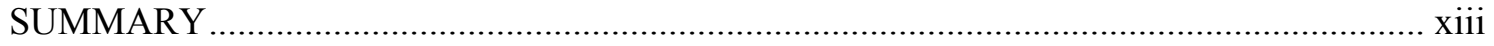

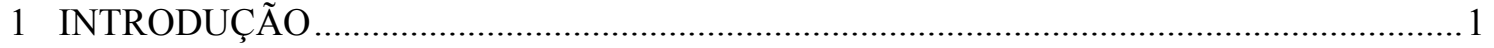

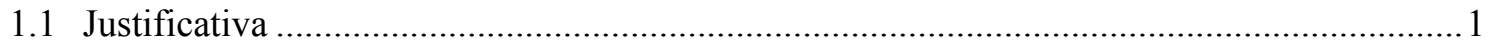

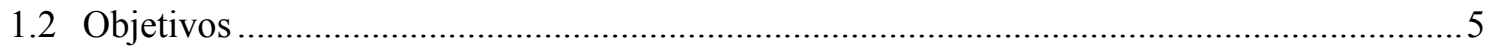

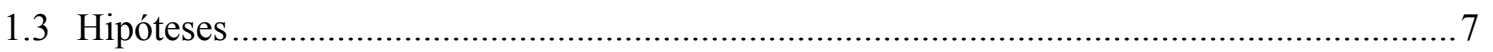

2 CONSIDERAÇÕES SOBRE OS PRODUTOS RESINOSOS.............................................

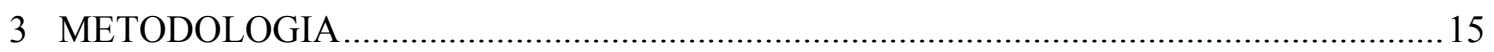

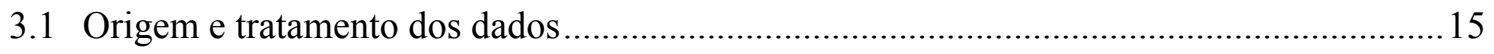

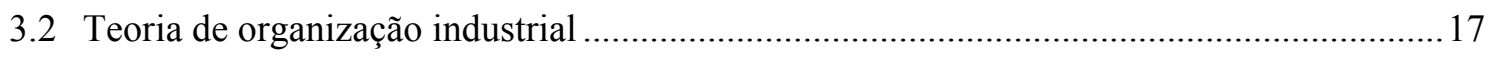

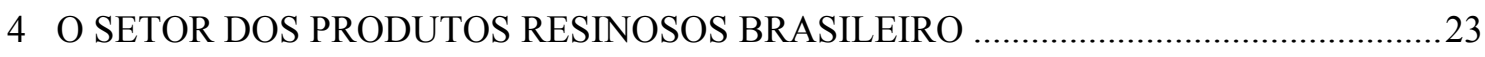

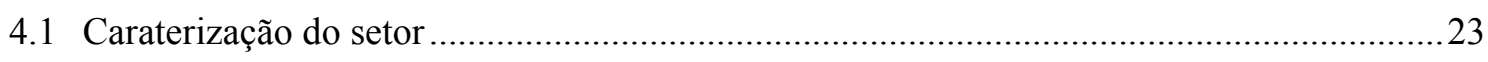

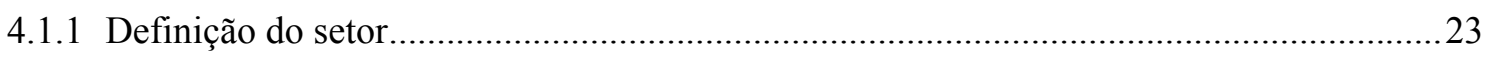

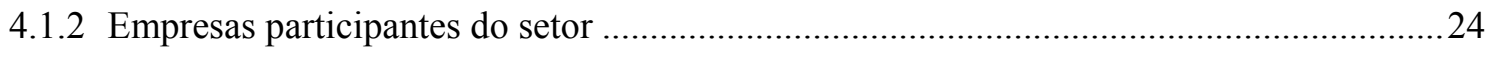

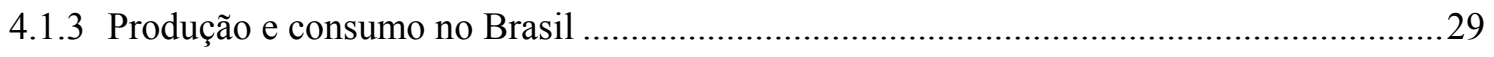

4.1.4 Produção e tendências Mundiais ...................................................................................... 33

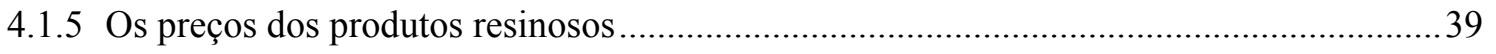

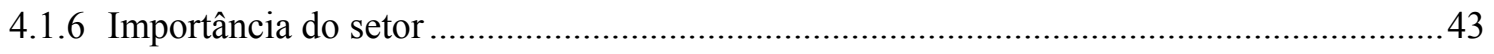

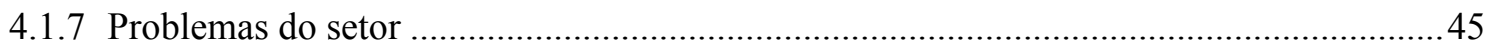

4.2 Tecnologia dos processos de fabricação ……............................................................ 49

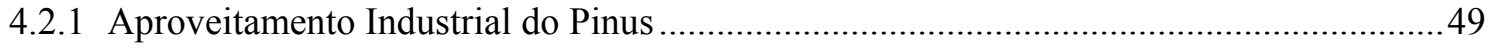

4.2.2 Descrição tecnológica da resinagem................................................................................50 
4.2.3 Descrição tecnológica do processamento da resina...........................................................55

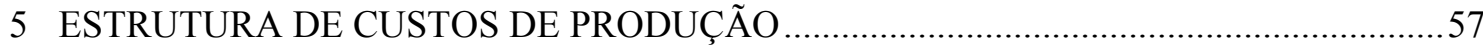

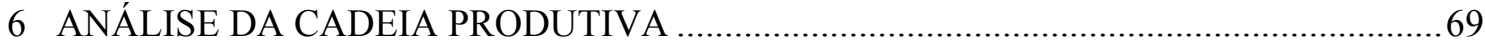

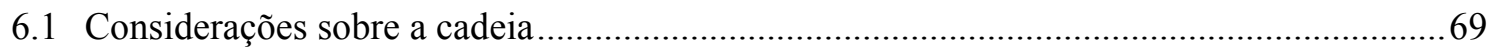

6.2 A formação e evolução das empresas do setor....................................................................71

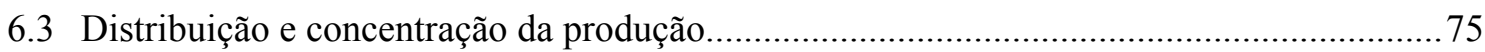

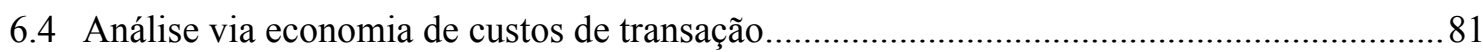

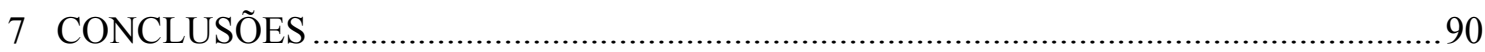

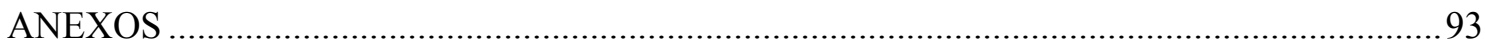

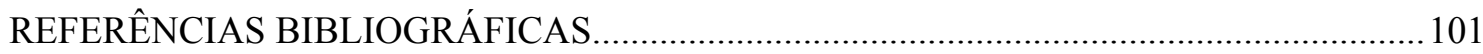




\section{LISTA DE FIGURAS}

Página

1 Fases da obtenção dos produtos resinosos (segmento dos produtos resinosos). ............... 10

2 Proporções médias dos derivados decorrentes da transformação da resina........................ 11

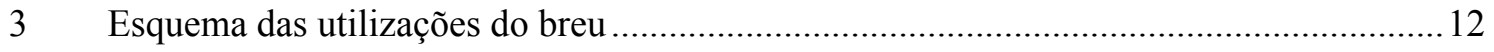

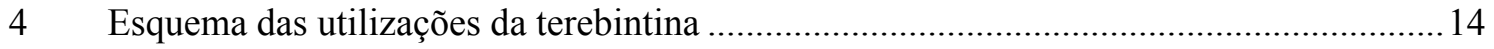

5 Relação entre Custos de Transação e Especificidade de Ativos (CT- custos de

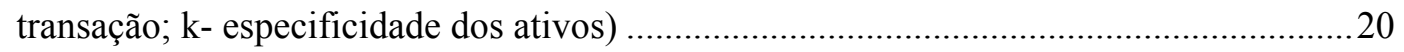

6 Formas organizacionais resultantes da Incerteza e Especificidade dos Ativos. ...............21

$7 \quad$ Sistema agro-industrial da goma-resina e seus derivados ..............................................24

8 Produções de resina, breu* e terebintina no Brasil de 1989-98 (em

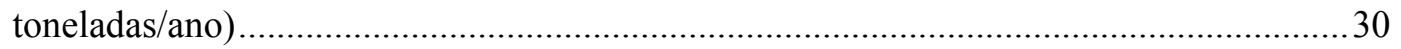

9 Produção*, exportação, importação e consumo* de resina no Brasil, 1992-98

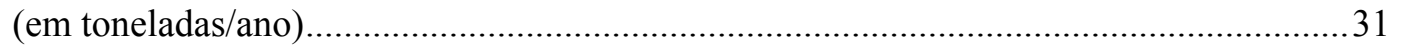

10 Produção**, exportação, importação e consumo* de breu no Brasil, 1992-98

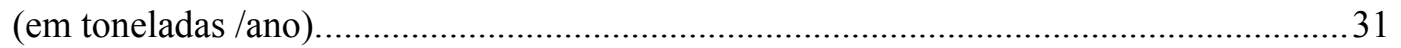

11 Produção*, exportação, importação e consumo* de terebintina no Brasil, 1992-

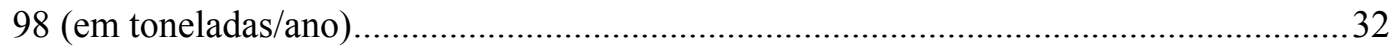

12 Produção, exportação e consumo de breu na China, de 1989-97 (em

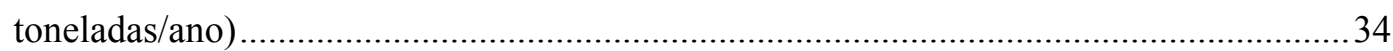

13 Produção de resina pelos principais produtores mundiais, excluindo a China, de

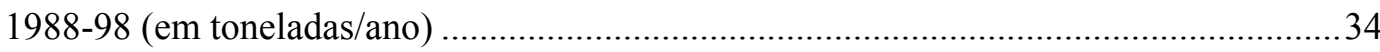

14 Produção de breu pelos principais países produtores, excluindo a China, 1989-

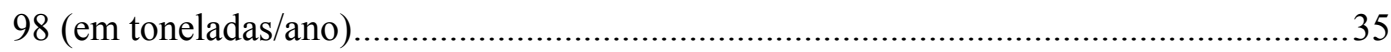

15 Exportação de breu pelos principais exportadores mundiais, de 1990 a 1998 (em toneladas /ano) 
16 Produção de breu de tall oil e importação do similar de origem na goma-resina

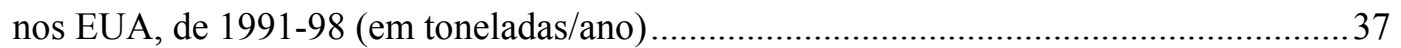

17 Principais importadores mundiais de breu, de 1989-98 (em toneladas/ano) .....................37

18 Evolução dos preços mensais da goma-resina, de Jan. 1984 a Out. 1998 (em US\$/tonelada).

19 Evolução dos preços médios mensais de resina, breu e terebintina no mercado interno, de Dez. 1994 a Abr. 1998 (em R\$/tonelada).

20 Evolução dos preços dos produtos resinosos de exportação no Brasil, de 1992 a 2000 (em US\$ FOB/tonelada)

21 Valor das exportação dos produtos resinosos no Brasil, 1992-00 (em 1000

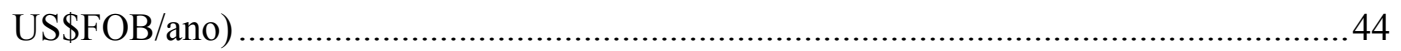

22 Distribuição da produção por Estados 1998 e 2000 (em percentagem). ............................ 76

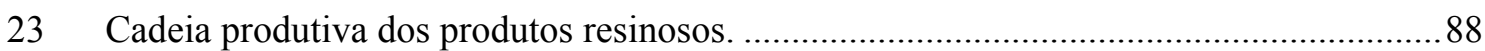




\section{LISTA DE TABELAS}

Página

1 Características de qualidade e quantidade de resina para algumas espécies de

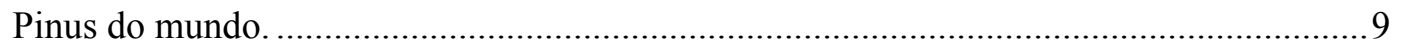

2 Algumas especificações no comércio internacional do breu ........................................... 12

3 Características físico-químicas da terebintina segundo a ISO 412-1976........................ 13

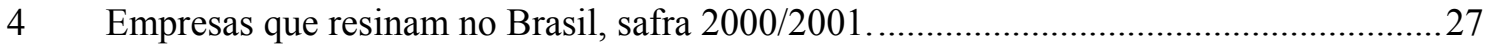

5 Empresas que processam goma-resina no Brasil, safra 2000/2001_...............................28

6 Produções de resina, breu e terebintina no Brasil, de 1989-98 (em

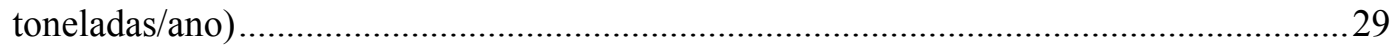

$7 \quad$ O mercado de resina no Brasil de 1992-98 (em toneladas/ano) ........................................29

$8 \quad$ O mercado de breu no Brasil de 1992-98 (em toneladas/ano) ...........................................30

9 O mercado de terebintina no Brasil de 1992-98 (em toneladas/ano)................................30

10 Produção de goma-resina dos principais países produtores, de 1988 a 1998 (em

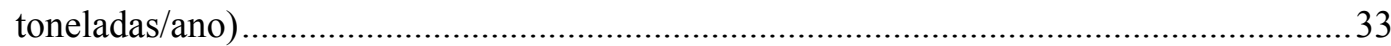

11 Produção de breu dos principais países produtores, de 1989 a 1998 (em

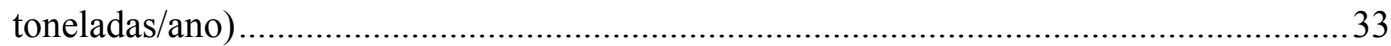

12 Valores de produção e comércio mundial de breu e terebintina (1000 t.) .........................38

13 Preços médios anuais de resina, breu e terebintina de exportação, de 1992 a 2000 (em US\$ FOB/tonelada).

14 Preços médios anuais de breu para exportação, de 1991 a 1995 (em US\$

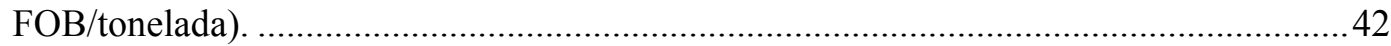

15 Distribuição do faturamento da indústria química brasileira, 1998 ..................................43

16 Valor das exportações de produtos resinosos no Brasil, de 1992 a 2000 (em 1000 US\$ FOB/ano)

17 O grau de importância considerado para os problemas do setor, segundo os resineiros. 
18 O grau de importância considerado para os problemas da atividades segundo as

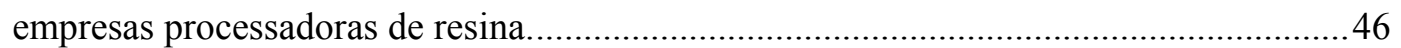

19 Produção de resina de Pinus por Kg / árvore / ano. .50

20 Previsão dos custos iniciais e anuais de produção da operação de resinagem para um país africano, a preços de 1995 (produção de 1000 toneladas de resina extraídas de 400.000 árvores).

21 Custos calculados para uma operação de resinagem em floresta de Pinus elliiottii em R \$ (2000) e safra 2000/01 (produção anual de 2.500 toneladas de resina extraídas de 1.000.000 de arvores).

22 Custos calculados para uma operação de resinagem em floresta de Pinus caribaea em R\$ (2000) e safra 2000/01 (produção anual de 3.200 toneladas de resina extraídas de 1.000.000 de árvores).

23 Comparação de percentuais de custos estimados para operações de resinagem na África e no Brasil para resina "elliottii" e "tropical"....

24 Cargas tributárias sobre a operação de resinagem.....

25 Previsão dos custos iniciais e anuais da operação de processamento da resina para um país africano, a preços de 1995.

26 Grau de importância atribuído aos custos presentes na operação de resinagem 2000 .

27 Grau de importância atribuído aos custos presentes na operação de processamento de resina, 2000.

28 Algumas empresas e entidades que arrendam suas florestas no Brasil

29 Empresas que deixaram de realizar a atividade de processamento de resina nos últimos 10 anos mas que continuam operando no setor a jusante no Brasil. .73

30 Evolução do número de empresas de resinagem segundo empresas de resinagem. .74

31 Evolução do número de empresas processadoras segundo a opinião dos resineiros e das empresas processadoras de resina. .74

32 Empresas exploradoras de resina no Brasil 1998 e 2000. .77

33 Empresas processadoras de resina no Brasil, 1999/2000. .78

34 Empresas do setor exclusivamente comerciais no Brasil, 1999/2000. .79 
36 Preocupações das empresas processadoras de resina para o período de 1990 a 2000, segundo a opinião das empresas resineiras e das empresas processadoras de resina.......

37 Os mercados destino dos diversos produtos resinosos.

38 Mercados finais dos produtos fabricados pelas empresas de processamento de resina, considerando o total das respostas.

39 Acerto dos preços da goma-resina das empresas resineiras com os compradores do ponto de vista dos resineiros.

40 Acerto dos preços da goma-resina das empresas resineiras com os compradores

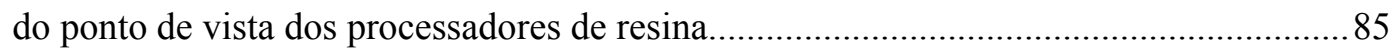

41 Grau de risco financeiro atribuído pelas empresas de resinagem às diversas

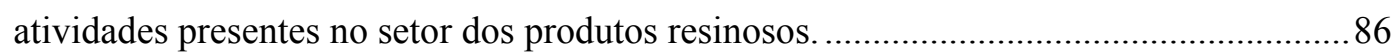

42 Grau de risco financeiro atribuído pelas empresas de processamento de resina às diversas atividades presentes no setor dos produtos resinosos. .........................................86

43 Resultados da auto-avaliação das empresas de resinagem e processamento de resina sobre suas próprias atividades. 


\title{
ANÁLISE DA CADEIA PRODUTIVA E ESTRUTURA DE CUSTOS DO SETOR BRASILEIRO DE PRODUTOS RESINOSOS
}

\author{
Autor: JOSÉ PINTO DA ROCHA JORGE FERREIRA
}

Orientador: Prof. Dr. LUIZ CARLOS ESTRAVIZ RODRIGUEZ

\section{RESUMO}

Este trabalho iniciou-se com a descrição da goma-resina, do breu e da terebintina. A primeira, extraída de plantios de Pinus elliotti e Pinus caribaea através da resinagem, é a matéria prima base da cadeia dos produtos resinosos. O breu e a terebintina, obtidos através do processamento da goma-resina, são seus primeiros derivados e são, por sua vez, matéria-prima de diversas indústrias químicas, como a de tintas, vernizes, colas, borrachas, desinfetantes, perfumaria, e outras. Passaram-se também em revisão os vários aspectos técnicos das operações de resinagem e, ainda, o processamento de resina. Igualmente se analisou a estrutura dos custos de produção, foram mensurados os custos específicos da operação de resinagem e, de forma menos aprofundada, os da operação de processamento de resina. Procedeu-se também à análise da cadeia produtiva, descrevendo o surgimento e a evolução do setor dos produtos resinosos brasileiro, a sua distribuição e concentração, sob a ótica da Economia dos Custos de Transação (ECT). A metodologia adotada neste trabalho baseou-se na análise gráfica e tabular de dados secundários e da pesquisa de campo realizada por intermédio de questionários, elaborados e lançados em articulação com a ARESB (Associação dos Resinadores do Brasil), e, ainda, de entrevistas com diversos empresários e representantes do setor. A produção brasileira satisfaz o consumo do país e ainda origina excedentes que são exportados e proporciona saldos comerciais positivos. O mercado internacional é dominado pela China que, com vastos recursos florestais e muita mão-de-obra disponível, responde por cerca de $65 \%$ da produção mundial e dita os preços 
dos produtos resinosos. A estrutura dos custos de produção da operação de resinagem, considerada um aspecto importante para a visualização dos problemas internos do setor, indica, sobretudo, uma importante participação do fator mão-de-obra, mas não se constataram níveis críticos relacionados aos seus custos como sucede atualmente em outros países produtores de resina. O setor, englobando empresas de resinagem e de processamento de resina, surgiu de esforços de grandes empresas das indústrias químicas e florestais, ainda hoje tem como agentes empresas provenientes de etapas a montante e a jusante na cadeia, e empresas estrangeiras que viram no Brasil a oportunidade de continuar ligadas a atividade. A produção está sobretudo localizada no Estado de São Paulo e o mercado, ao contrário do que se pressupunha, não se encontra concentrado em algumas empresas. Observando os parâmetros de ECT utilizados na análise da cadeia produtiva, a forma híbrida das estruturas de governança parece ser a predominante no setor. À semelhança de uma cadeia agro-industrial normal, o setor apresenta estrutura de governança voltada para o mercado nos estágios iniciais da cadeia, tendendo ao longo da cadeia, no sentido jusante, para situações hierarquizadas. Verifica-se uma tendência de verticalização das empresas de processamento de resina e derivados para montante como forma de garantir suas matérias primas. 


\section{PRODUCTIVITY CHAIN ANALYSIS AND COST STRUCTURE OF THE BRAZILIAN NAVAL STORES PRODUCTS}

Author: JOSÉ PINTO DA ROCHA JORGE FERREIRA

Adviser: Prof. Dr. LUIZ CARLOS ESTRAVIZ RODRIGUEZ

\section{SUMMARY}

This paper is initiated with the description of gum resin, gum rosin and turpentine. Gum resin, mainly extracted from Pinus elliottii and Pinus caribaea plantations, is the basic raw material in the production chain. Gum rosin and turpentine are the first two products obtained after processing the pine gum, and are themselves used as raw material in the chemical industry to produce paints, varnishes, glues, rubber, perfumes, disinfectants, and others. The gum resin extraction and the technical aspects of its processing are revised. Tapping, industrialization and the whole production cost structure are also analyzed. The origin and evolution of the industry is analyzed, as well as its distribution and concentration, and the production chain is described from a Transaction Cost Economy (TCE) point of view. The methodology adopted in this study is based on graphical and tabular analysis of secondary data, interviews with industry owners and managers, and information collected from questionnaires jointly designed with the Brazilian Gum Resin Producers Association (ARESB). Brazilian production covers domestic demand, and the surplus generated is exported. The international market is controlled by China, which with large forest and labor resources accounts for approximately $65 \%$ of the world production and establishes prices. Labor is the main item in the extraction costs structure, but is not as problematic as in other producing countries. The gum rosin and turpentine production segment, initially developed in Brazil by large forest and chemical companies, is still led today by groups positioned upstream and downstream in the production chain, and by foreign enterprises that have seen in Brazil the opportunity to maintain their link with the activity. Production is mainly 
located in the State of São Paulo, and the market, contrarily to what was expected, does not concentrates in a few companies. According to the TCE parameters used in the production chain analysis, a hybrid governing structure comes up as the predominant structure in this segment. Similarly to a common agribusiness, the chain's initial stages are market orientated, but towards the end of the chain the segment shows a more hierarchical structure. A trend to verticalization upstream is also noted on gum rosin and turpentine producers, in order to guarantee adequate stocks of raw material. 


\section{INTRODUÇÃo}

\subsection{Justificativa}

Resina é o nome genérico de uma classe de substâncias que se encontram em árvores e que, no Brasil, em níveis comerciais, são extraídas de espécies do gênero Pinus, mais precisamente do Pinus elliottii e Pinus caribaea. Trata-se de um líquido viscoso inflamável, de cor translúcida amarelo/marrom a branco e apresentando um forte odor. Suas propriedades são muitas, explicando as diversas aplicações que teve ao longo de mais de 5000 anos de utilização, e tem, ainda, atualmente, na indústria química.

Caracteriza-se o setor dos produtos resinosos como o conjunto das empresas que realizam atividades envolvendo resina ou seus derivados. O setor é muito antigo no mundo, pois há muitos séculos atrás já se extraia resina em vários países. No Brasil, a resinagem começou há aproximadamente 25 anos e atualmente encontra-se numa posição de destaque no mercado mundial.

O governo e as suas instituições de controle como o IBAMA e Institutos Estaduais de Florestas não reconhecem nem realizam qualquer tipo de controle sobre as atividades desse setor, regendo-se o setor pelas leis de mercado. Apenas alguns produtores e empresários se aperceberam das potencialidades do mercado brasileiro, mas aparentemente com pouca contribuição para que o seu desenvolvimento fosse ordenado. Ainda hoje não se encontram registradas as razões deste crescimento. 
Apesar deste crescimento e das nítidas vantagens em produtividade que o solo brasileiro apresenta, o setor no Brasil enfrenta muitos problemas. Alguns, de ordem técnica a exigir mais pesquisa e desenvolvimento, e outros, de ordem econômica, requerendo um desenvolvimento ordenado como forma de aumentar a competitividade dos seus produtos.

Entre estes problemas alguns advêm internamente do Brasil, como a redução nas áreas de floresta e pequeno desenvolvimento da pesquisa, e outros externamente ao Brasil com a concorrência com outros produtores mundiais como a China, que lidera com larga margem a produção mundial e dita os preços e as regras no mercado externo.

Apesar de bastante questionável, segundo alguns empresários do setor, as atividades de base deste setor necessitam de regulamento ou incentivo por parte do governo, pois o fato da produção de resina utilizar mão-de-obra intensiva prevê uma alta futura nos preços dos produtos nacionais derivada de questões trabalhistas e da elevação dos salários, à semelhança do que aconteceu em outros países.

Este estudo pretende esclarecer eventuais lacunas de informação dentro do setor dos produtos resinosos no Brasil, caracterizando-o economicamente e enfocando principalmente os aspectos econômicos da estrutura de custos de produção, distribuição e concentração da produção, e outros relativos à análise da cadeia produtiva.

As principais preocupações e a necessidade de um estudo como este foram apresentadas em reunião onde estiveram presentes diversos representantes do setor (IPEF, 1998) ${ }^{1}$. Os objetivos escolhidos foram resultado da discussão que abrangeu grande parte dos problemas do setor, nomeadamente a falta de definição de um rumo para o mercado nacional e a possibilidade de intensificação do comércio exterior, com crescente grau de competição com o produto chinês; a necessidade de uma coordenação de esforços para viabilizar o desenvolvimento de projetos de pesquisa; e a definição de estratégias que permitam ganhos de produtividade e redução de custos. $\mathrm{Na}$ área econômica, esta proposta faz parte deste esforço concentrado.

${ }^{1}$ INSTITUTO DE PESQUISAS E ESTUDOS FLORESTAIS. Criação do Programa Nacional de Competitividade do Setor Brasileiro de Produção de Goma-Resina, Piracicaba, 17/09/98, 4p. (Memória de Reunião). Fundação Florestal; Associações de Produtores e Consumidores de Resina; Comercial. Majuara Ltda.; Correnteza Consultoria Rural; Dasotec; Harima do Brasil Ind. Quím. Ltda.; Ouvires Florestais Ltda.; Planebrás Com. Plan. Florestais S.A.; Resineves Agroflorestal Ltda.; Resiserv Com. de Resina Serv. Ltda.; Resinas do Paraná Ind. Com. Ltda.; Sociedade Luso Brasileira Ext. Com. de Resinas Ltda.; e Socer Brasil Indústria e Comércio Ltda. 
Dentre os produtos de origem florestal, a resina é um dos menos estudados em termos econômicos. Aspectos técnicos envolvendo aumento do potencial produtivo através do melhoramento genético, introdução de procedências mais produtivas, melhorias silviculturais no manejo e nos processos de extração, entre outros, demonstram o potencial de se obter 5 a 6 $\mathrm{kg} /$ árvore/ano em florestas novas (Augusto Filho, 1994). Este valor representa mais que o dobro dos 2,5 kg/árvore/ano extraídos, em média, de florestas maduras no Estado de São Paulo.

A importância da resinagem no Brasil pode ser avaliada pelo volume de produção, facilidade de industrialização da resina bruta e pela diversidade de aplicações dos produtos obtidos a partir da primeira transformação.

A resinagem no Brasil, iniciada na década de 70, evoluiu até que, próximo de 1990, o país passou da condição de importador para a de exportador (Figueiredo Filho et al., 1992). Tal reversão na balança comercial do produto possibilitou não só a redução de dispêndios como a geração de divisas para o País. O País, segundo este autor, é atualmente o segundo maior produtor mundial, perdendo apenas para a China.

A resinagem no Brasil pode se beneficiar da alta produtividade potencial dos seus plantios de Pinus, uma vez que o clima oferece condições ótimas para a produção in natura da resina. Também, juntamente com outras atividades florestais relativas à exploração de madeira, a resina contribui para dar à floresta um cunho altamente social (Garrido, 1996). A exploração da resina, além de antecipar receitas para o proprietário florestal e gerar empregos diretos, contribui também para a fixação do homem no meio rural. No Brasil, a exploração de mais de 45 milhões de árvores implica no emprego direto de aproximadamente 12 mil pessoas e indireto de outras tantas na indústria química.

Além disso, a resinagem, contrariamente a outras atividades florestais, é uma atividade que não tem o problema do grande horizonte de tempo para a amortização do investimento, pois, a partir de um curto espaço de tempo, tem início um fluxo anual constante de receitas.

Segundo Garrido et al (1998), a atividade de resinagem, quando bem realizada, pode tornar-se mais que uma fonte de renda complementar à exploração da madeira. Um exemplo ilustrativo é que o proprietário de uma árvore com 10 anos de idade, que produza 2 a $3 \mathrm{Kg}$ de 
resina por ano, pode ver a sua árvore arrendada a uma empresa resineira, recebendo pelo aluguel uma porcentagem aproximada de 20 a 30\% da resina produzida. Como a árvore pode produzir por mais de 15 anos, o proprietário da árvore recebe mensalmente, de acordo com o preço da resina, um total médio de US\$2,50 a 5,00 por árvore, e ainda teria a madeira para vender no final que renderia mais US\$2,00 a 4,00. Ou seja, teria um aumento no total das receitas de 10 a $20 \%$ a favor da resinagem.

Segundo a Associação dos Resinadores do Estado de São $\mathrm{Paulo}^{2}$, citado em Baena (1994), evidencia-se uma vantagem adicional, relativamente a florestas não resinadas, de US\$ 624,00 por hectare de Pinus elliottii resinado em grandes empresas do Paraná. Considerando para um período de 8 anos, uma perda de $31,00 \mathrm{~m}^{3}$ (4,6\%) de madeira como conseqüência da resinagem, produções de $2 \mathrm{Kg}$ por árvore/ano e que o proprietário recebe geralmente $25 \%$ da produção, resulta no final uma receita líquida de US\$ 810,00. Subtraindo US\$186,00 referentes à perda de crescimento da madeira, resulta no valor final de US\$ 624,00, não considerando ainda os juros proporcionados pela antecipação das receitas da resina comparadas com as florestas não resinadas, onde só nos cortes haverá receita.

Baena (1994) estudou a viabilidade econômica da resinagem de Pinus elliottii Engelm. Var. elliottii nas regiões do sul do estado do Paraná e sul e sudoeste do Estado de São Paulo. Com este objetivo, simulou perdas de incremento no volume de madeira de 5, 15 e 30\%, melhoramentos genéticos de 25,50 e $75 \%$ sobre os volumes tradicionais e taxas de juros de 6,9 e $12 \%$ a.a. para cálculos de valor presente líquido (VPL), análise beneficio/custo (B/C) e taxa interna de retorno (TIR). Os resultados mostraram a viabilidade econômica nas condições mais frias do Estado do Paraná, com aumento da rentabilidade em todas as alternativas que consideraram a resinagem, em comparação às florestas não resinadas.

O trabalho observou, ainda, aumento de rentabilidade nas florestas melhoradas geneticamente. Na alternativa resinada "em vida", no Paraná, nas condições normais e esperadas (15\% de perdas, taxa de juros $9 \%$ a.a.), o VPL foi de US\$ 661,55/ha e 1,29 para a B/C, contra US\$ 73,55/ha negativos e $\mathrm{B} / \mathrm{C}$ de 0,96 na alternativa não resinar. Na melhor alternativa, considerando perdas de $5 \%$ e ganho genético de $75 \%$, a taxa interna de retorno do projeto atingiu

\footnotetext{
${ }^{2}$ ASSOCIAÇÃO DOS RESINADORES DO ESTADO DE SÃO PAULO. Boletim Informativo Mensal, n. 1, jan.1993. 17p.
} 
17,5\% a.a., e o VPL para uma taxa de juros de $9 \%$ a.a. resultou igual a US\$ 4.286,11/ha, com uma razão benefício/custo de 2,30.

O consumo médio brasileiro de breu, de 1975 a 1989, segundo Figueiredo Filho et al. (1992) como derivado da goma-resina, foi de, aproximadamente, 35.000 ton./ano e até meados da década passada uma boa parte dessa quantidade era importada. Com a implantação de florestas de Pinus, subsidiadas por incentivos fiscais a novos reflorestamentos nos anos 60, 70 e 80 , houve incremento da atividade da resinagem e o Brasil passou a produzir em torno de 80.000 ton./ano de goma-resina. A partir de 1989, dá-se início à exportação do excedente da produção em relação ao consumo interno. Esta atividade resulta em uma receita anual que ultrapassa os US\$ 24 milhões, contribuindo economicamente para a sustentabilidade de atividades florestais em regiões carentes de outras oportunidades. Atualmente, a produção brasileira se aproxima das 100.000 toneladas por ano com aparente potencialidade de aumentar.

O crescimento em produção e importância do setor de resinas no Brasil não é condizente com as informações disponíveis e os estudos de desempenho do setor. Este fato motivou o esforço de pesquisa que gerou este trabalho.

\subsection{Objetivos}

Este trabalho tem como objetivos gerais a caracterização e análise econômica do setor dos produtos resinosos. Procuram-se informações que auxiliem a compreensão e avaliação do desempenho dos processos de produção e comercialização da goma-resina a partir de florestas de Pinus. Desta forma, são caracterizadas as relações de produção e distribuição presentes na cadeia produtiva da resina, desde a sua extração na floresta até a sua conversão em breu ou terebintina.

As duas etapas que caracterizam o processo de comercialização, ou seja, (I) produção e extração na floresta, e (II) aquisição, transporte e primeira transformação da resina nos derivados, são avaliadas juntamente, tendo em vista que o processo muitas vezes se encontra verticalizado (os produtores de derivados são produtores de resina). 
A realização deste trabalho baseia-se em levantamentos obtidos a partir de um contato direto com as empresas que realizam a extração, a comercialização e o processamento da gomaresina. Estão envolvidas também entidades e associações oficiais e privadas vinculadas às atividades de resinagem nos Estados de São Paulo e Paraná.

Apesar da ênfase regionalizada no Estado de São Paulo, o estudo procura envolver outros pólos de produção nacionais, avaliando a sua importância relativa e mecanismos de escoamento da produção. É também objetivo a contextualização da atividade de resinagem em termos nacionais e diagnóstico do seu potencial de competitividade com o produto similar importado.

A revisão de literatura evidencia a carência de estudos na área econômica, principalmente na área de abrangência deste trabalho. As poucas referências encontradas não se aprofundam em estudos de mercado ou análises econométricas, mas apenas em avaliações da viabilidade econômica da operação de resinagem. É objetivo geral deste trabalho amenizar esta carência.

Os objetivos principais deste trabalho inserem-se majoritariamente em dois pontos de estudo:

I. Estrutura de custos de produção;

II. Análise da cadeia produtiva.

São objetivos específicos deste estudo, envolvendo o setor dos produtos resinosos no Brasil:

- Caracterização do setor e das atividades que o compreendem;

- Composição e análise dos principais itens de custo;

- Análise da distribuição geográfica de produção de resina e derivados;

- Avaliação dos níveis de concentração da produção de resina e derivados;

- Análise da cadeia, utilizando a Economia dos Custos de Transação. 
Este trabalho apresenta-se organizado da seguinte forma. Primeiramente, na introdução, são apresentados o problema, a justificativa, a motivação e os objetivos. Depois segue-se uma capítulo de metodologia em que se indica a origem e o tratamento dos dados e qual a metodologia de análise teórica utilizada.

São descritos os produtos resinosos para melhor compreensão da cadeia e passa-se à caracterização do setor com todas as definições necessárias (tipo de empresas, as produções e consumos, as tendências e problemas que enfrenta e, ainda, são descritos os processos tecnológicos das operações de resinagem e processamento de resina). Os dois capítulos seguintes são: a estrutura dos custos de produção que vai caracterizar e mensurar os custos específicos da operação de resinagem e de um modo semelhante, mas menos aprofundado, os da operação de processamento de resina; e a análise da cadeia produtiva, observando o surgimento e evolução do setor, sua distribuição e concentração e a análise via Economia dos Custos de Transação. Finalmente, são resumidas as conclusões do trabalho e apresentada a bibliografia.

Não se realizou um capítulo abordando a revisão de literatura uma vez que esta é dispersa e sobretudo de caráter técnico. Deste modo, a pouca bibliografia encontrada foi inserida oportunamente no texto em cada um dos capítulos.

\subsection{Hipóteses}

1. Comparativamente aos níveis de produção de outros países, o Brasil pode ser considerado um importante produtor no cenário mundial.

2. Os custos relacionados com a mão-de-obra são considerados o principal fator limitante à expansão do setor dos produtos resinosos no Brasil.

3. A produção da resina natural e o seu processamento se encontram concentrados.

4. Verifica-se uma tendência das empresas processadoras de verticalizarem suas operações a montante. 


\section{CONSIDERAÇÕES SOBRE OS PRODUTOS RESINOSOS}

Os produtos resinosos podem ser obtidos de três fontes distintas:

- Goma-resina ou resina natural (gum resin) - a partir da coleta de resina de árvores vivas (resinagem) por meio de um processo de exsudação da goma resina semelhante ao da extração da borracha. Posteriormente, via lavagem e destilação obtém-se o breu (gum rosin) e a terebintina (turpentine).

- Resina de tall oil ou talóleo (crude tall oil) - subproduto da transformação da madeira em celulose pelo processo sulfatado (kraft). Obtém-se a terebintina sulfatada (sulphate turpentine) e o breu de talóleo (tall oil rosin). Para além disso, obtêm-se também os chamados ácidos graxos ou tall oil fatty acids.

- Resina de madeira (wood resin) - através de um processo tecnológico de secagem e extração dos componentes resínicos presentes na madeira e realizado fora da floresta. São obtidos os produtos breu natural (wood rosin), terpenos e óleo de pinho, entre outros.

Embora a goma-resina seja a fonte mais utilizada no Brasil (resinagem de árvores vivas), isto não significa que as outras fontes não sejam rentáveis no mercado mundial. Os EUA são um importante produtor de resina de talóleo (e um pequeno produtor de resina natural). Como o rendimento do talóleo para o Pinus elliottii var. eliottii se situa entre 45 e $90 \mathrm{Kg} / \mathrm{ton}$. de celulose, a sua extração poderá ser interessante para as fábricas brasileiras de celulose, tal como já é prática comum na maioria das fábricas norte-americanas.

Naval Stores é o termo anglo-saxônico pelo qual são conhecidos os produtos resinosos no mercado mundial. São considerados commodities florestais e compreendem a resina e os seus derivados. Esta designação provém da sua antiga aplicação na construção e calafetagem naval (pitch and taar) utilizada na Marinha Real Inglesa (Gurgel Filho, 1972). 
Nas florestas de Pinus considera-se ainda a possibilidade de as árvores destinadas a produzir celulose poderem primeiro passar por um processo de resinagem a partir do qual se extrai breu e terebintina e, posteriormente, nas fábricas de celulose, a sua madeira ser utilizada para retirar o tall oil e terebintina sulfatada, obtendo-se assim uma produção dupla de resinas.

A goma-resina no Brasil é extraída das espécies Pinus elliottii var. elliottii, e Pinus caribaea de variedades caribaea, hondurensis e bahamensis. Trata-se de um líquido viscoso inflamável, de cor translúcida amarelo/marrom a branco e apresentando um forte odor. A distinção entre tipos de resina prende-se ao tipo de derivados que esta vai originar, conforme é explicado mais à frente, e as suas características variam com a espécie e com as condições do meio. Como se pode observar na Tabela 1, as espécies presentes no Brasil são das mais vantajosas tanto em quantidade produzida como em qualidade.

Tabela 1. Características de qualidade e quantidade de resina para algumas espécies de Pinus do mundo.

\begin{tabular}{|c|c|c|}
\hline Espécies & Qualidade & Quantidade \\
\hline$\overline{\text { Pinus elliottii }}$ & ++ & ++ \\
\hline Pinus pinaster & ++ & + \\
\hline Pinus massoniana & + & + \\
\hline Pinus merkusii & + & + \\
\hline Pinus caribaea & + & +++ \\
\hline Pinus radiata & +++ & + \\
\hline Pinus roxburghii & + & + \\
\hline Pinus kesiya & + & - \\
\hline Pinus oocarpa & - & - \\
\hline Pinus sylvestris & - & - \\
\hline Pinus patula & - & - \\
\hline
\end{tabular}

Fonte: Koppen \& Hone, 1995.

Nota: as características são escaladas de muito bom (+++) a fraca (-), esta classificação não resulta de experimentos em situações equivalentes mas valores médios fornecidos por região ou país.

As utilizações da resina são antigas e vêm variando ao longo dos tempos e compreendem as mais diversas aplicações. A título de curiosidade, os egípcios utilizavam-na para fins 
religiosos e na mumificação dos corpos (Homa, 1983), os gregos utilizavam-na (e ainda utilizam) na produção de vinho, e os fenícios e os romanos usavam-na para calafetar os seus navios, utilização esta que se manteve através dos séculos até os dias de hoje, ou seja, durante mais de 2000 anos. Atualmente, a resina pura tem poucas aplicações, e geralmente serve de matéria-prima para outros produtos através dos seus derivados. As aplicações dos derivados diversificaram-se de tal modo que se torna difícil definir qual a sua principal utilização. Mais adiante são especificadas as aplicações da resina consoante o derivado que originam.

Podem-se observar duas fases (Figura 1) até a obtenção dos seus derivados: (I) a resinagem, ou seja, a produção e extração de resina na floresta; e (II) a primeira transformação, que compreende o processamento da resina bruta na fábrica, pela lavagem e destilação, daí se obtendo o breu e a terebintina que, como referimos, são consideradas matérias primas.

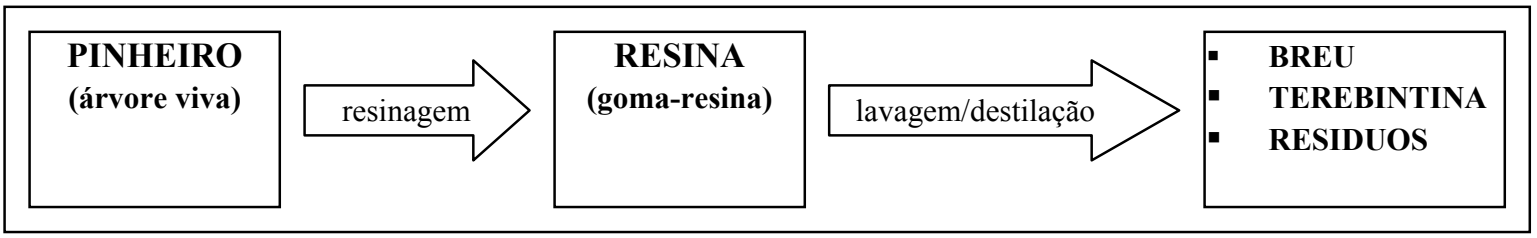

Figura 1 - Fases da obtenção dos produtos resinosos (segmento dos produtos resinosos).

Fonte: Pesquisa do autor (2001)

Neste processamento (descrito mais adiante) são separadas primeiramente a resina pura e os resíduos numa proporção próxima de 8:2 e em seguida os derivados breu (ou pez ou colofônia) e terebintina (ou aguarrás) em proporções que variam consoante a espécie dentro dos intervalos:

- Breu -60 a $85 \%$

- Terebintina - 15 a $30 \%$

Os resíduos são constituídos por água e impurezas orgânicas como folhas, pequenos ramos, cascas da árvore etc. Separados da resina, quando da sua transformação em breu e terebintina, são considerados externalidades sem utilização aparente. Pela proporção que se apresenta na Figura 2., o breu é o principal produto. Trata-se de um sólido transparente de 
aparência vítrica devido à inexistência de impurezas (ao contrário do que se verifica na resina), e que possui características físico-químicas variáveis, dentro de determinada gama, e pelas quais é classificado e vendido. Como características determinantes pode-se referir o caráter ácido, insolubilidade na água mas não em certos solventes orgânicos, e sem odor marcante (Tabela 2). A cor, cristalização e o ponto de amolecimento são geralmente os indicadores de qualidade base utilizados pelos compradores na distinção dos produtos.

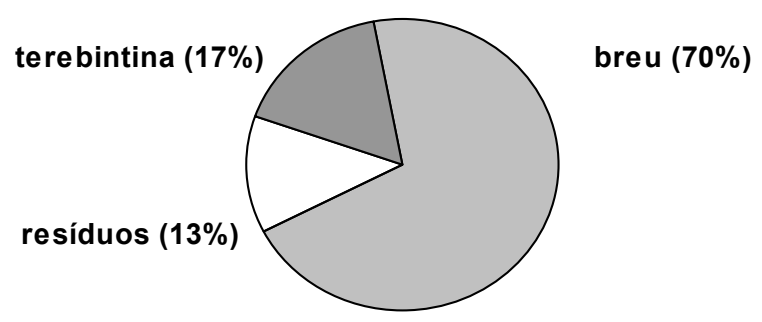

Figura 2 - Proporções médias dos derivados decorrentes da transformação da resina.

A escala de cores utilizada na comercialização é representada pelas seguintes letras $\mathrm{H}, \mathrm{I}$, $\mathrm{K}, \mathrm{M}, \mathrm{N}, \mathrm{WG}$ (window-glass), WW (water-white), X, Y, 2A, 3A, 4A e 7A, em que as últimas são as de melhor qualidade. Podem também ser utilizadas as cores Gardner com equivalência nas outras.

No entanto, para a indústria, várias outras características físico-químicas influenciam a qualidade deste produto ${ }^{3}$. Estas variam com a espécie, com a estação em que a árvore se encontra (local, região, país) e com a técnica de extração utilizada. O principal fator responsável pelas características da resina, e, por conseqüência, do breu, é a espécie de pinheiro de onde é extraída a resina e até mais precisamente a subespécie e genética da árvore.

\footnotetext{
${ }^{3}$ Sendo difícil definir um padrão internacional para o breu, a caracterização apresentada segue as diretivas, testes e métodos da ASTM (American Society for Testing and Materials). No entanto, convém referir que as características desejadas para o breu variam com o país, com a empresa ofertante, e com a utilização pretendida para o breu. Geralmente as empresas e traders criam as suas próprias especificações.
} 
O breu é utilizado como matéria-prima para a elaboração de tintas, vernizes, lacas, sabões, colas, graxas, esmaltes, ceras, adesivos, desinfetantes, explosivos, isolantes térmicos etc. (Augusto Filho, 1994).

Tabela 2. Algumas especificações no comércio internacional do breu

\begin{tabular}{lccccc}
\hline \multicolumn{1}{c}{ Origem } & Cor & $\begin{array}{c}\text { Ponto de } \\
\text { amolecimento }\left({ }^{\circ} \mathrm{C}\right)\end{array}$ & $\begin{array}{c}\text { Índice de } \\
\text { acidez }\end{array}$ & $\begin{array}{c}\text { Índice de } \\
\text { Saponificação }\end{array}$ & $\begin{array}{c}\text { Matéria não } \\
\text { saponificável (\%) }\end{array}$ \\
\hline China & WW & $70-85$ & $162-175$ & - & Max 7.5 \\
Portugal & WW & Min 70 & $165-171$ & $171-177$ & $4.3-5.5$ \\
Brasil & $\mathrm{X} / \mathrm{WW}$ & $70-78$ & $155-170$ & $165-185$ & Max 10 \\
Indonésia & $\mathrm{WW} / \mathrm{WG}$ & $75-78$ & $160-200$ & $170-210$ & - \\
\hline
\end{tabular}

Fonte: Koppen \& Hone, 1995.

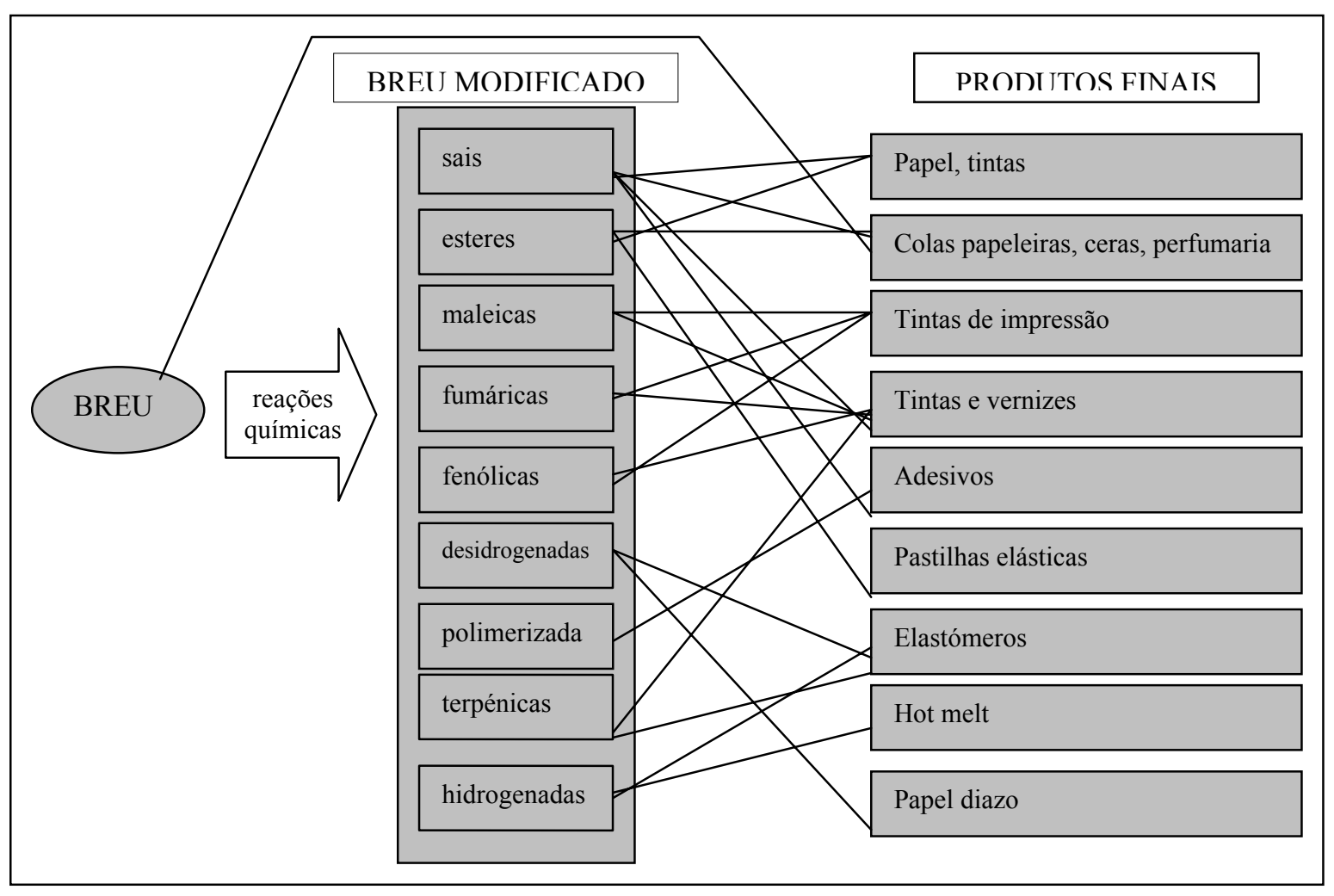

Figura 3 - Esquema das utilizações do breu 
A terebintina é um líquido volátil transparente de odor marcante a Pinus (responsável pelo odor da resina). Este produto possui, segundo a International Organization for Standardization $^{4}$ (ISO), características específicas, como se pode observar de um modo geral no Quadro 3. Estas podem variar dentro de determinados limites para cada país, e também consoante a composição dos seus constituintes.

Tabela 3. Características físico-químicas da terebintina segundo a ISO 412-1976.

\begin{tabular}{|c|c|c|c|c|c|c|}
\hline $\begin{array}{l}\text { Densidade } \\
\text { relativa } \\
\left(20 / 20^{\circ} \mathrm{C}\right)\end{array}$ & $\begin{array}{c}\text { Índice de refração } \\
\left(20^{\circ} \mathrm{C} \text {, linha D) }\right.\end{array}$ & $\begin{array}{c}\text { Destilação } \\
(\% \mathrm{v} / \mathrm{v})\end{array}$ & $\begin{array}{l}\text { Resíduo de } \\
\text { evaporação } \\
(\% \mathrm{~m} / \mathrm{m})\end{array}$ & $\begin{array}{c}\text { Resíduo após } \\
\text { polimerização } \\
(\% \mathrm{v} / \mathrm{v})\end{array}$ & $\begin{array}{l}\text { Valor } \\
\text { ácido }\end{array}$ & $\begin{array}{l}\text { Ponto de } \\
\text { "Flash" } \\
\left({ }^{\circ} \mathrm{C}\right)\end{array}$ \\
\hline $0,862-0,872$ & $1,465-1,478$ & $\begin{array}{l}\text { Max } 1 \text { abaixo de } 150^{\circ} \mathrm{C} \\
\text { Min } 87 \text { abaixo de } 170^{\circ} \mathrm{C}\end{array}$ & Máx 2,5 & Máx 12 & Máx 1 & Min 32 \\
\hline
\end{tabular}

Nota: pode-se também incluir como anexo a definição ISO para Portugal, terebintina tipo Pinus pinaster (1994), o grau de rotação óptica a $20^{\circ} \mathrm{C}$ de $-28^{\circ}$ a $-35^{\circ}$.

Fonte: Koppen \& Hone, 1995.

Para a indústria consumidora de terebintina um outro requerimento importante é o número de constituintes e sua percentagem na composição. Como se pode observar na Figura 4, para cada aplicação específica da terebintina há um constituinte que se torna mais importante. A maior procura é pela terebintina com maiores percentagens de pinênos (principalmente alfapinêno e beta-pinêno), tornando-a a mais valiosa. Considerando este aspecto, o Brasil está em vantagem uma vez que o seu principal tipo de pinheiro, Pinus elliottii contêm elevada percentagem de pinênos:

- Pinus elliottii : Alfa-pinêno (60\%) e Beta-pinêno (30\%)

- Pinus caribaea : Alfa-pinêno (40 a 55\%) e Beta-pinêno (5 a 15\%)

- Pinus radiata : Alfa-pinêno (30-40\%) e Beta-pinêno (50-60\%)

- Pinus pinaster : Alfa-pinêne (72-85\%) e Beta-pinêno (12-20\%).

\footnotetext{
${ }^{4}$ Trata-se de uma federação mundial de institutos de padronização de produtos, que define e rotula
} 


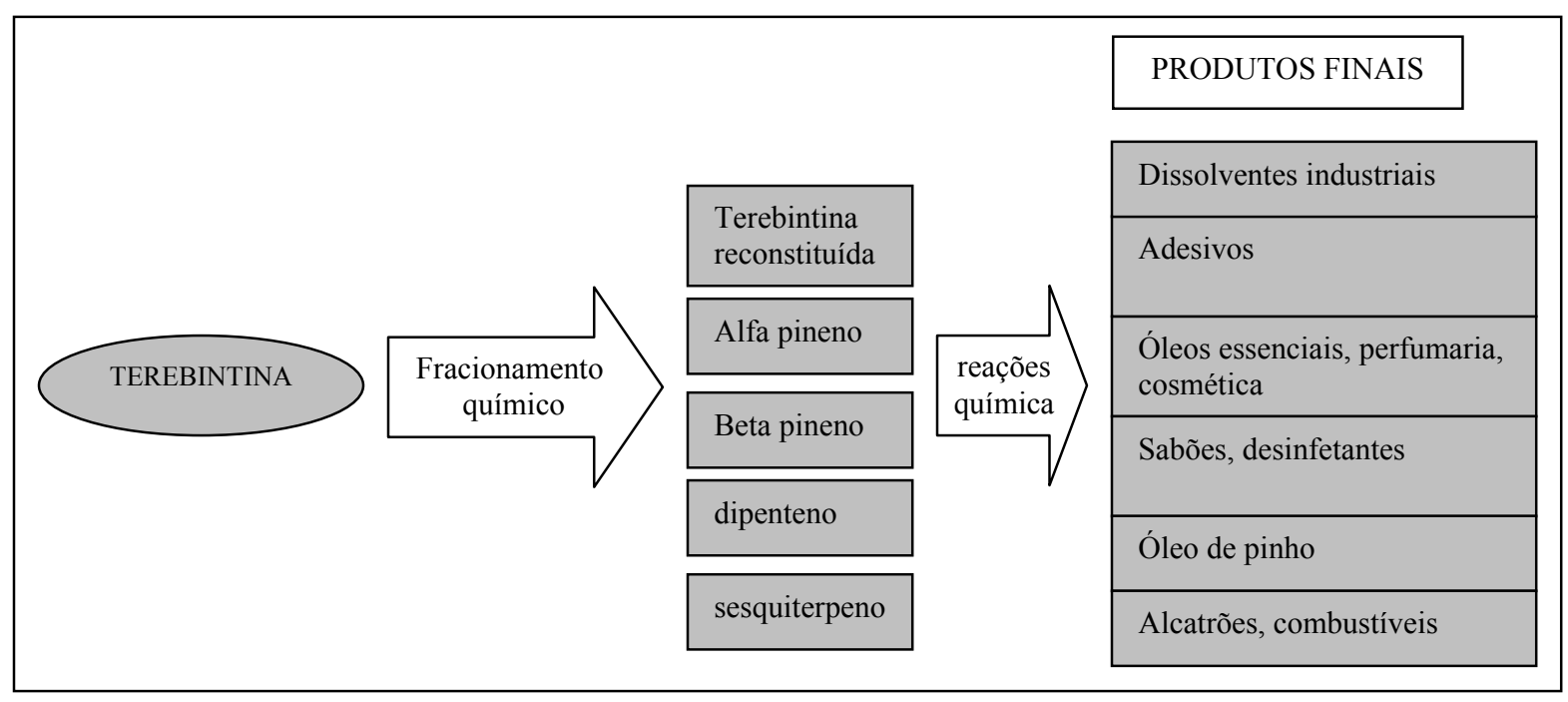

Figura 4 - Esquema das utilizações da terebintina

A terebintina, de um modo geral, é utilizada como constituinte de líquidos de limpeza, desinfetantes, inseticidas, germicidas, tintas, vernizes, corantes, vedantes para madeira, reagentes químicos, cânfora sintética, desodorantes, óleos etc. (Augusto Filho, 1994).

produtos. É especialmente importante no ramo dos produtos químicos. 


\section{METODOLOGIA}

\subsection{Origem e tratamento dos dados}

Este estudo foi realizado em função de três atividades:

1. Atualização da revisão bibliográfica, envolvendo o levantamento de estatísticas e dados do setor;

2. Levantamento de informações por meio de questionários e entrevistas junto a produtores florestais, comerciantes e industriais ligados ao setor produtor e processador de goma-resina;

3. Organização e análise das informações coletadas visando à caraterização geral do setor; sua estrutura de custos de produção e análise da cadeia produtiva compreendendo o surgimento e evolução do setor, a distribuição e concentração da produção e a caracterização e análise dos aspetos da ECT do setor.

De um modo geral, a informação contida nos capítulos seguintes foi coletada durante a realização das duas primeiras atividades enunciadas acima e organizada durante a terceira atividade de modo a fornecer ao leitor um texto completo, organizado e elucidativo do setor dos produtos resinosos brasileiros.

Verificou-se uma certa dificuldade na obtenção de dados estatísticos de cadeias temporais longas, prejudicando a pesquisa na totalidade do período de existência dos produtos resinosos no Brasil, que é de aproximadamente 25 anos.

A pesquisa de campo, por meio de questionários (vide Anexos), mostrou-se necessária para completar grandes lacunas de informação existentes na bibliografia e para esclarecer alguns 
dados dispersos na literatura. Os questionários, embora elaborados de modo a obter o maior número possível de informações sobre o setor, visavam sobretudo a responder a questões específicas tratadas nos capítulos 4 e 5, sobre a estrutura dos custos de produção e análise da cadeia produtiva via ECT. A razão da elevada abrangência dos questionários prende-se à falta de informação sobre o setor e construção de um banco de dados que possa ser utilizado em futuras pesquisas. São inúmeras as áreas de pesquisa e grande a vontade das empresas de contribuir. A ARESB (Associação dos Resinadores do Brasil), entidade que reúne grande parte dos produtores de resina no Brasil, participou da definição dos grupos e entidades questionadas, fornecendo alguns dados e endereços de contato. O envio dos questionários realizou-se durante o segundo semestre de 2000 .

Das 44 empresas que realizam a atividade de resinagem apenas $29 \%$ responderam aos questionários enviados. Relativamente às empresas de processamento de resina, foram apuradas 12 mas apenas 50\% responderam. Não obstante essas participações, as empresas que retornaram os formulários representam, em conjunto, uma importante parcela do setor dos produtos resinosos no Brasil, correspondendo aproximadamente a $50 \%$ da produção atual brasileira de goma-resina de Pinus e $65 \%$ da capacidade instalada da indústria processadora de resina, de tal sorte que a análise das respostas pode ser estendida para o restante da resinagem e indústria sem maiores problemas.

Foram utilizadas análises gráficas e tabulares de informações bibliográficas e algumas informações obtidas nos questionários, no capítulo 4. Neste capítulo são identificadas e fornecidas as características gerais e específicas do setor em pequenos pontos de fácil compreensão.

A estrutura dos custos de produção, considerada de suma importância para a compreensão e análise de alguns dos principais problemas do setor (nomeadamente para visualização da participação da mão-de-obra nos custos gerais), foi obtida também por análises gráfica e tabular. É interessante analisar a tecnologia envolvida nas operações, pois esta vai determinar alguns dos custos envolvidos.

De um modo simplificado construiu-se uma planilha detalhada de custos para as operações de resinagem, identificando e analisando todos os pontos considerados mais 
importantes. Já para a operação de processamento de resina é dada uma ênfase mais generalizada dos seus custos, equiparando-os aos de uma empresa da indústria química brasileira.

Ferramentas da Teoria de Organização Industrial foram utilizadas como base para a análise do setor. Assim, observou-se o surgimento e evolução do mesmo, complementando-se as informações da bibliografia com as da pesquisa direta. Utilizaram-se os índices de concentração de mercado para verificação da distribuição e concentração da produção e a Economia de Custos de Transação (ECT) e seus parâmetros para a análise da cadeia produtiva apresentadas em seguida.

\subsection{Teoria de organização industrial}

A decisão entre "comprar" ou "fazer" participa do cotidiano dos gestores das empresas dos setores florestais. Mas quais serão estas decisões influenciadas por aspectos institucionais?. E constatando empresas com diferentes estruturas de governança no setor, o que as leva a adotar estas estruturas? Neste sentido, a Teoria da Organização Industrial pode oferecer uma importante contribuição uma vez que seu principal objetivo é analisar como a estrutura da organização e a conduta dos compradores e vendedores afetam o desempenho e o bem estar econômico considerando a forma como está estruturado o mercado em que atuam.

A referência normalmente utilizada para o estudo do ambiente da empresa, dado pela economia neoclássica, é considerada avançada em termos de formalismo e elegância conceitual, porém criticada, por alguns autores, por apresentar um nível de afastamento continuado de realidade econômica. A Nova Economia das Instituições (NEI), seguindo conceitos idealizados por economistas como Ronald Coase e Oliver Williamson, surge como uma nova e importante referência teórica alternativa para a explicação dos processos de escolha das formas organizacionais.

Neste contexto, considerando os problemas relacionados à tomada de decisão por parte das empresas e organizações, a Economia dos Custos de Transação (ECT), considerada uma ferramenta de pesquisa da NEI, é a que procura maior aderência à realidade, a que mais se 
preocupa com este tipo de questões, e sobretudo, a mais utilizada na explicação e resolução de problemas de coordenação vertical de cadeia agro-industriais.

Na NEI, as organizações são definidas como um conjunto de contratos que funcionam como os "elos" das cadeias produtivas. Olha-se a empresa não como uma sinergia tecnológica (uma função de produção) mas como um conjunto de contratos. Esses contratos podem variar e representam um acordo entre comprador e vendedor, em que são definidos nos termos de troca, o preço, a especificidade dos ativos e salvaguardas.

Os Custos de Transação, segundo Williamson (1993), podem ser definidos como os custos de desenhar e monitorar os contratos, ou seja, são os pontos de análise da organização vista como um conjunto de contratos.

Uma vez que a NEI pretende captar a organização como ela é, ou seja, considerando as suas falhas reais, foram estabelecidas pressuposições básicas acerca do comportamento dos agentes: a racionalidade limitada e o oportunismo. Como conseqüências destes dois pressupostos comportamentais:

- Os contratos são incompletos e muitos processos complexos de organização das transações deixam de ser utilizados em função da racionalidade limitada dos agentes;

- O contrato não é totalmente confiável uma vez que existe comportamento oportunista dos agentes;

- Aumentos de eficiência nas transações serão conseguidos com a redução da limitação da racionalidade e inclusão de salvaguardas capazes de reduzir os riscos de oportunismo.

É neste contexto que se define o problema da escolha de formas organizacionais mais eficientes. Estas são aquelas que minimizam, além dos custos derivados da transformação, os custos de transação e também as que mais facilmente se adaptam às mudanças institucionais. A hipótese básica da ECT é a de que a eficiência das organizações é dada pelo alinhamento entre as transações (que diferem em seus atributos) e as estruturas de governança (que diferem em seus custos e capacidade de minimizar os custos de transação), para um dado ambiente institucional. 
O nível de integração será decorrente dos atributos das transações (especificidade dos ativos, freqüência e risco) e dos parâmetros ditados pelo ambiente institucional onde a empresa ou organização está inserida. Assim, nem sempre a solução de integração é a melhor. Analisando as condições específicas nas quais a empresa opera, vão se observar as melhores formas de conduzir a produção, seja ela interna (verticalizada), via mercado ou através de estruturas mistas (híbridas) entre mercados e interna, que caracterizam vários tipos de formas contratuais como associações estratégicas, franquias, contratos de distribuição, entre outras (Zylbersztajn, 1995).

Podem-se identificar seis tipos de especificidade de ativos:

- Especificidade locacional - respeitante à localização relativa de firmas responsáveis por etapas sucessivas da mesma cadeia produtiva, favorável à economia de despesas com armazenagem e transporte;

- Especificidade de ativos físicos - referente às características físicas inerentes ao produto transacionado cujo uso é específico, como por exemplo uma forma para produzir um componente;

- Especificidade de ativos humanos - relativa à experiência profissional adquirida;

- Especificidade de marca - referente ao capital que se materializa no nome de um produto ou empresa;

- Ativos dedicados - diz respeito a investimentos realizados para um cliente em especial, a quem se restringe a utilidade de tais investimentos;

- Especificidade temporal - referente ao investimento para garantia de ganho no tempo em que se processa a transação, particularmente importante no caso de produtos perecíveis.

Observando a Figura 5, pode-se inferir acerca das diferentes estruturas de governança. Considerando a especificidade dos ativos, quanto maior especificidade, maior as "quasi-rendas" produzidas, maior a necessidade de controle sobre a transação e, por conseguinte, maior a tendência à integração vertical; teremos então a forma hierárquica $(\mathrm{H})$. Por outro lado, numa situação de baixa especificidade de ativos, estes podem ser realocados para outras transações com relativo baixo custo (associado a ações oportunistas), e portanto, favorecendo a transação no mercado (M). Não vai haver formas de controle e o sistema de preços é suficiente para assegurar o ajuste do mercado e a plena realização das transações. O meio termo será considerado a forma híbrida (X). 
Resumindo, as estruturas de governança podem ser:

- via mercado, através do relacionamento entre as diferentes empresas;

- hierárquica, por meio da internalização por parte de uma empresa de várias etapas ou atividades correlatas na cadeia, $\mathrm{e}$

- híbrida ou mista, que pressupõe a existência de contratos de longo prazo entre os diferentes agentes envolvidos numa transação.

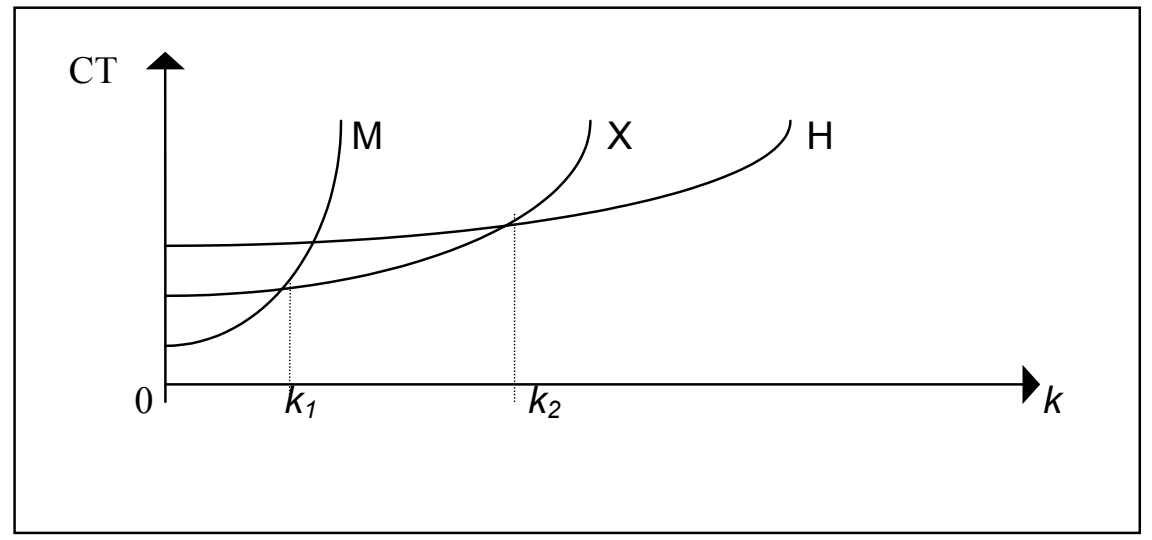

Figura 5 - Relação entre Custos de Transação e Especificidade de Ativos (CT- custos de transação; k- especificidade dos ativos)

Fonte: Bueno, 1998.

Relativamente à componente freqüência, quanto maior for esta, maior a possibilidade de internalizar a etapa em questão, sem perder a eficiência relacionada à escala. Uma transação realizada esporadicamente não justifica o estabelecimento de relações contratuais de longo prazo, nem mesmo da sua integração vertical, mas a necessidade constante de realização da transação pode justificar a internalização desta etapa produtiva.

Azevedo (1996), identifica duas formas de incerteza associadas à transação. Uma, designada por risco, corresponde à probabilidade de ocorrer um distúrbio de acordo com uma distribuição conhecida. A segunda, que corresponde de fato à incerteza, corresponde aos distúrbios que afetam a transação, mas sem uma distribuição de probabilidades conhecida. Um 
exemplo deste tipo de incerteza é a assimetria de informações entre os agentes envolvidos na transação, que os impossibilita de prever a forma de atuação um do outro.

Uma vez que os pressupostos de racionalidade limitada e oportunismo continuam vigorando mesmo após a vigência do contrato ${ }^{5}$, é necessária a consideração de custos adicionais decorrentes da implementação, monitoramento, bem como readaptação/renegociação dos contratos.

Em termos práticos, a escolha entre integração vertical (forma hierárquica), formas híbridas (ou contratos de longo prazo) ou mercado para governar a transação, é a questão abordada na ECT que mais interessa para a empresa (Figura 6). Esta questão é decorrente da opção adaptabilidade da empresa via preços e os custos de controle e monitoramento.

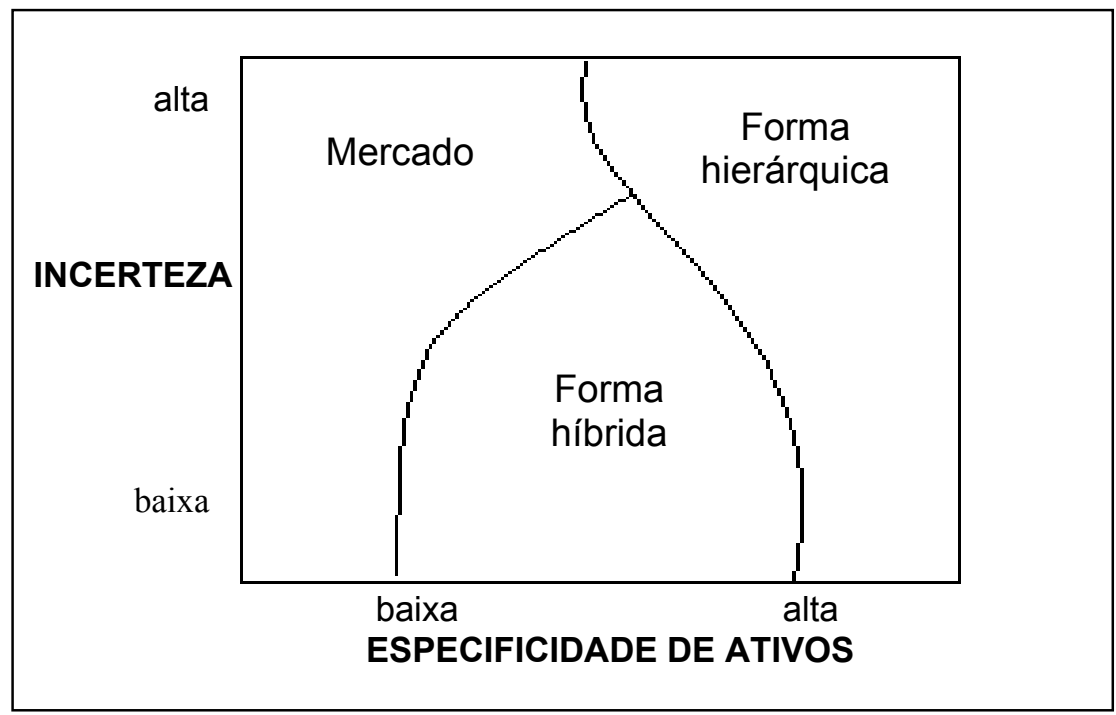

Figura 6 - Formas organizacionais resultantes da Incerteza e Especificidade dos Ativos.

Fonte: Bueno, 1998.

${ }^{5}$ Considerando os princípios comportamentais dos agentes participantes e, portanto, a existência de contratos imperfeitos torna-se bastante difícil a previsão no contrato "ex ante" de todas as situações que podem vir a ocorrer "ex post". 
Finalizando, segundo Williamson, a teoria de ECT, quando comparada a outras abordagens de estudo das organizações econômicas e de custos de transação, apresenta sucintamente as seguintes vantagens, daí a sua utilização neste trabalho:

- é mais microanalítica;

- incorpora suposições comportamentais;

- introduz e desenvolve a importância econômica da especificidade dos ativos;

- considera elementos de análise institucional comparativa;

- reporta-se ao ambiente da empresa como estrutura de governança ao invés de função de produção;

- coloca maior peso na forma "ex post" dos contratos. 


\section{O SETOR DOS PRODUTOS RESINOSOS BRASILEIRO}

\subsection{Caraterização do setor}

\subsubsection{Definição do setor}

O setor dos produtos resinosos é delimitado pelo conjunto das atividades relacionadas com a extração, industrialização e comercialização da goma-resina e seus derivados.

Trata-se de um Sistema Agro-industrial (SAG) à semelhança do que sucede com outros produtos agrícolas e florestais. Analisando a cadeia em que este se encaixa, inicia-se com os insumos utilizados na floresta que irão gerar a produção de resina, até abranger os produtos oferecidos ao consumidor ou até a incorporação em outros setores a jusante (Figura 7).

Os produtos, em cada etapa da cadeia, vão ser influenciados, em parte, pelos preços e disponibilidades dos produtos que se encontram "atrás" de si, na cadeia. Neste contexto, observando o setor, pode tornar-se interessante para uma empresa que opera num determinado segmento da cadeia controlar atividades a montante e a jusante.

Verifica-se igualmente uma progressão do valor agregado dos produtos nas diferentes fases da transformação da resina. Obter produtos com um valor agregado cada vez mais significativo poderá constituir o maior desafio que se coloca aos industriais do setor brasileiro, pelo que representa em termos de conquista de novos mercados e consolidação das posições do setor. 


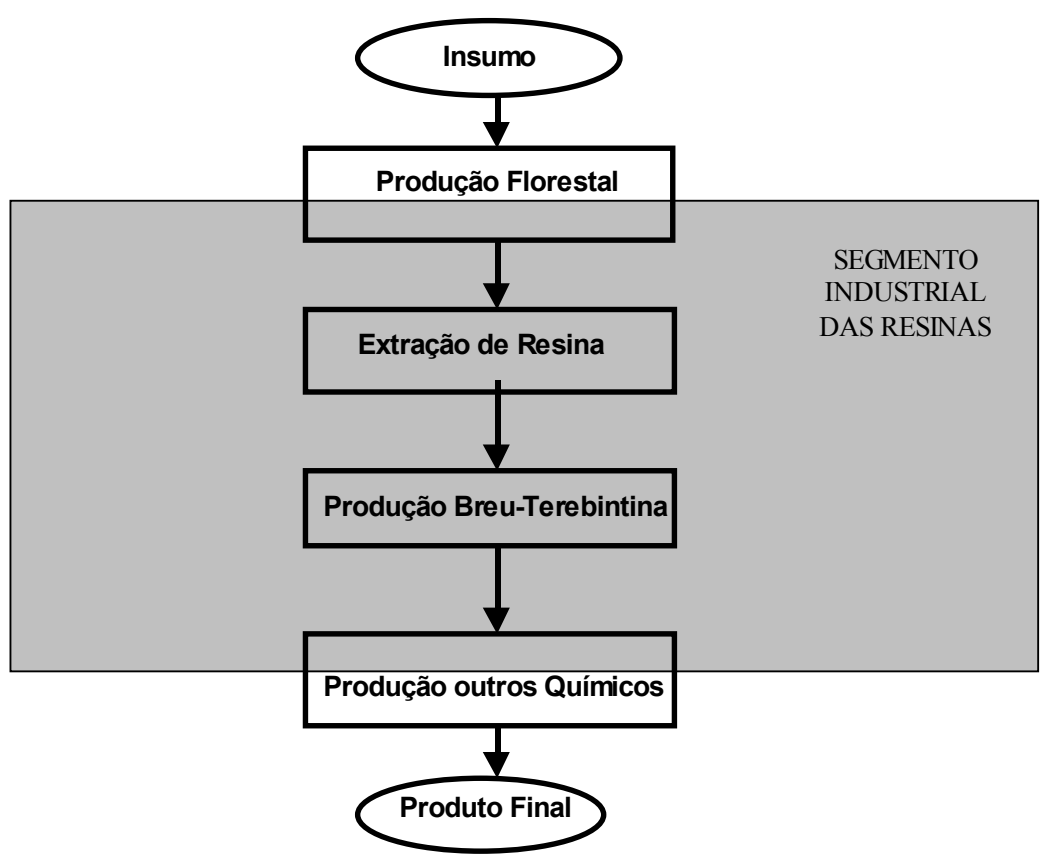

Figura 7 - Sistema agro-industrial da goma-resina e seus derivados

Também pelos seus valores de produção, capacidade de inovação tecnológica (P\&D), e abertura, o setor tem-se revelado um grande mercado e alvo de investimentos exteriores. O país está atualmente entre os maiores produtores mundiais de produtos resinosos, distanciado apenas da China.

\subsubsection{Empresas participantes do setor}

O setor dos produtos resinosos no Brasil, de um modo geral, é formado por cinco tipos de empresas:

- Empresas proprietárias florestais ou entidades florestais que arrendam suas florestas

- Empresas de resinagem

- Empresas de produção de breu e terebintina

- Empresas de produção de derivados de breu ou de terebintina

- Empresas que comercializam produtos resinosos 
As primeiras representam as florestas de Pinus onde é extraída a resina. No Brasil, as florestas de Pinus foram plantadas sobretudo na época dos incentivos fiscais ao florestamento e reflorestamento que começou com força nos anos 60 e continuou no caso do pinheiro até os anos 80, princípios de 90. Atualmente a área de floresta de Pinus no Brasil situa-se entre 1 e 2 milhões de hectares, mas diminuindo, uma vez que, na década atual, se completa o ciclo de corte da floresta, ou seja, as florestas estão a ser cortadas sem haver reflorestamento significativo.

Estas florestas podem ser gerenciadas pelos próprios proprietários, por empresas do ramo das serrarias de madeira, de celulose e papel, aglomerados, carvoaria, por entidades públicas no caso de florestas do Estado ou federais, e ainda por outras formas. Há situações em que estas empresas florestais, pessoas ou entidades, "entram" no negócio das resinas procedendo elas próprias à extração da goma. E há a situação em que estas arrendam as suas florestas a empresas especializadas em resinagem recebendo um valor pelo arrendamento que pode ser monetário ou em resina definindo-se uma percentagem mensal ou anual. Este último caso é o mais comum. O proprietário recebe geralmente uma percentagem da produção total mensal ou anual de resina, normalmente de 20 a $30 \%$. A empresa proprietária da floresta não procede à extração da resina mas fica com resina que pode comercializar no mercado ou simplesmente vender para a empresa resineira que a extraiu.

Dentre as empresas brasileiras que arrendam suas florestas para empresas de resinagem pode-se mencionar: Alcatex, Banestado Reflorestadora, Duraflora, Eucatex Florestal, Fazenda Santa Andréa, Fundação Consumo Produtos Florestais do Estado de São Paulo, IBAMA, ORSA Celulose e Papel S.A., consideradas grandes empresas florestais brasileiras.

O segundo tipo de empresas, de resinagem ou de produtores autônomos, procede à extração da resina da árvore e sua comercialização. Segundo informações da $\operatorname{ARESB}^{6}$ (1999) o número de produtores de goma-resina para a safra de 1998/99 era 54. Atualmente, de acordo com a pesquisa efetuada (Tabela 4), contam-se 44, havendo ainda muitas indefinições relativamente à atuação de pequenos resineiros autônomos. O número de pessoas empregadas neste tipo de empresas pode variar entre 25 e 500 funcionários, situando-se a média de aproximadamente 35 funcionários.

\footnotetext{
${ }^{6}$ ARESB. Dados dispersos. São Paulo 1999. (correspondência pessoal)
} 
Os restantes tipos de empresas presentes no setor pertencem ao ramo da indústria química brasileira. Segundo dados da Associação Brasileira de Indústrias Químicas - ABIQUIM (1999), a indústria química mundial, por razões técnicas e econômicas, é basicamente constituída de grandes empresas. Para o caso brasileiro, segundo a PIA-IBGE, 1996, as empresas químicas de pequeno porte (que mantém menos de 30 empregados) representavam $68 \%$ do número total de empresas no setor, no entanto eram responsáveis por apenas $12 \%$ dos empregos e $5 \%$ do faturamento.

Deste modo, o terceiro tipo de empresas - as fábricas processadoras de goma-resina - são consideradas empresas da indústria química de pequeno a médio porte. Estas realizam a atividade industrial de limpeza e destilação da goma-resina, bem como a comercialização do breu e terebintina.

Segundo Ferreira ${ }^{7}$, citado em Baena (1994), 17 fábricas localizadas principalmente no Estado de São Paulo, mas também com presenças no Paraná, Santa Catarina, Rio Grande do Sul e Rio de Janeiro processavam, em 1993, cerca de 45.000 toneladas de resinas. Atualmente, segundo a pesquisa efetuada, contam-se cerca de 12 fábricas distribuídas pelos estados de São Paulo, Paraná, Santa Catarina, Rio Grande do Sul, e Minas Gerais (Tabela 5) processando quantidades de resina superiores a 80.000 toneladas por ano.

As empresas produtoras de derivados do breu e terebintina no Brasil são, geralmente, grandes indústrias químicas de difícil identificação e quantificação. As opções de produtos derivados do breu e terebintina são distintas e muito variadas tornando difícil o trabalho de identificação e mensuração destas.

\footnotetext{
${ }^{7}$ FERREIRA, A.P. A resinagem no estado do Paraná. Irati: SESI, 1993. 10p.
} 
Tabela 4. Empresas que resinam no Brasil, safra 2000/2001.

\begin{tabular}{|c|c|c|}
\hline & Empresa & Município - UF \\
\hline 1 & Admire Agro Florestal & Buri SP \\
\hline 2 & Agostinho Ferreira & $--\mathrm{SP}$ \\
\hline 3 & Agropecuária 5 Mar Ltda. & Paranapanema SP \\
\hline 3 & Antônio Carlos Stecca & Buri SP \\
\hline 4 & Areovaldo Calin Manoel & Itapeva SP \\
\hline 5 & ArtPinus Resineira Ltda. & Itapeva SP \\
\hline 6 & Atílio & -- PR \\
\hline 8 & Carlos A Rodrigues & -- SP \\
\hline 9 & Cláudio de Nadae & Cerquilho SP \\
\hline 10 & CMA Ind. Ltda & Campina Monte Alegre SP \\
\hline 11 & Comercial Majuara Imp. Exp & Itapetininga SP \\
\hline 12 & Comercial Mato Verde & Itapetininga SP \\
\hline 13 & Comercial Tibagi / Lisandro & Taquarivaí SP \\
\hline 14 & Cond. Reserva Palmares & Palmares RS \\
\hline 15 & Dasotec Planej. Florest. Ltda & Curitiba PR \\
\hline 16 & Emílio Tozoni & Manduri SP \\
\hline 17 & Faz. Holambra & $--\mathrm{SP}$ \\
\hline 18 & Guedes & -- SP \\
\hline 19 & Habitasul Resinagem & Cidreira RS \\
\hline 20 & Henrique Souza Fernandes & Buri SP \\
\hline 21 & João Schulomei & -- SP \\
\hline 22 & Nercilio Justino Rodrigues & Avaré SP \\
\hline 23 & Osvaldo Souza Lima & Uberlândia SP \\
\hline 24 & Ourives & -- PR \\
\hline 25 & Paracatu Faz Anaconda & $--\mathrm{SP}$ \\
\hline 26 & Passareli Agro Pecuária Ltda & CerqueiraCesár SP \\
\hline 27 & Pedro Italiano & -- SP \\
\hline 28 & Pedro Quioboa & $--\mathrm{SP}$ \\
\hline 29 & Planebrás Com.Plan Flor. S/A & Buri SP \\
\hline 30 & Raul Semedo & -- SP \\
\hline 31 & Reginaldo & $--\mathrm{SP}$ \\
\hline 32 & Resilayn E. C. E. Ltda & Manduri SP/MG/PR \\
\hline 33 & Resimar Ltda & Itaí SP \\
\hline 34 & Resineves AgroFlorestal Ltda. & Itapeva SP/PR \\
\hline 35 & Resinorte Agroflorestal Ltda. & Montes Claros MG \\
\hline 36 & Resiserv Com. Resina Ltda. & Itapetininga SP \\
\hline 37 & Resisul & Itapeva SP \\
\hline 38 & Resitrop Ltda. & Montes Claros MG \\
\hline 39 & Rosendo & $--\mathrm{SP}$ \\
\hline 40 & Roveda & -- SP/PR \\
\hline 41 & S.O .Resinas Prod. Com. & Itu SP \\
\hline 42 & SLB Extração e Com. Resinas Ltda. & Manduri SP \\
\hline 43 & Socitec Extração e Com. Resinas Ltda. & Perdizes MG \\
\hline 44 & Tomio dos Santos Kubo & Itapirapuã Paulista SP/PR \\
\hline
\end{tabular}

Fonte: Pesquisa do autor, 2000 
Tabela 5. Empresas que processam goma-resina no Brasil, safra 2000/2001.

\begin{tabular}{lll}
\hline & \multicolumn{1}{c}{ Empresa } & \multicolumn{1}{c}{ Município - UF } \\
\hline 1 & Breuquímica Ind. Com. Ltda. & Itatinga SP \\
2 & CMA Ind. Ltda. & Campina Monte Alegre SP \\
3 & Especialidades Quím. Paraná & Curitiba PR \\
4 & Habitasul Ind. Química Ltda. & Cidreira RS \\
5 & Harima do Brasil Ind. Quím. Ltda. & Ponta Grossa PR \\
6 & Resinas Brasil Ind. Com. Ltda. & Manduri SP \\
7 & Resinas do Paraná Ind. Com. Ltda. & Sengés PR \\
8 & Resinas Tropicais Ind. Com. Ltda. & Uberlândia MG \\
9 & Resinas Yser Ltda. & Campo Largo PR \\
10 & Resinit Ltda. & Itapeva SP \\
11 & Roveda Ind. Química Ltda. & Caçador SC \\
12 & Socer Brasil Ind. Com. Ltda. & Salto SP \\
\hline
\end{tabular}

Fonte: Pesquisa do autor, 2000.

Finalmente, existem as empresas que comercializam produtos resinosos. Elas compram, vendem e podem, inclusive, mandar processar por terceiros os produtos resinosos das diversas etapas da cadeia. Apurou-se um número de quatro para as empresas que se dedicam exclusivamente à comercialização de produtos resinosos sem realizar resinagem ou processamento de goma ou derivados.

No entanto, cada uma das empresas de resinagem ou processamento descritas anteriormente podem se inserir nesta classificação. Assim, há empresas produtoras de resina que comercializam também breu e terebintina e há empresas produtoras de derivados de breu e terebintina que comercializam resina e seus derivados. Considerando ainda as que comercializam derivados do breu e terebintina, existem empresas que compram resina e contratam as fábrica processadoras desta para lhes obter breu e terebintina que então comercializam

É também sabida a existência de grupos de empresas que trabalham exclusivamente entre si, ou seja, elas não incorporam as diversas fases da cadeia, são empresas distintas juridicamente, mas, pertencendo ao mesmo grupo, vão funcionar em função das necessidades umas das outras podendo comercializar os seus produtos fora do grupo, quando as necessidades do grupo estiverem preenchidas ou quando surgirem oportunidades favoráveis. 
Todas as empresas que realizam as etapas visualizadas na Figura 7 podem se verticalizar e incorporar várias fases da cadeia englobando-se em mais de um dos vários tipos de empresas mencionadas acima.

\subsubsection{Produção e consumo no Brasil}

As produções brasileiras de produtos resinosos atingem atualmente valores consideráveis. Tratando-se de um setor relativamente recente é de louvar a rapidez com que fez crescer as suas produções e o país que era importador de produtos resinosos passou à condição de exportador. Os seus produtos resinosos são essencialmente de origem na goma-resina, portanto proveniente de florestas de Pinus, não havendo dados sobre quaisquer outras proveniências no Brasil quer seja de tall oil ou de secagem da madeira.

As tabelas e gráficos apresentados em seguida mostram as proporções e as taxas de crescimento dos produtos resinosos, suas produções e seus consumos.

Tabela 6. Produções de resina, breu e terebintina no Brasil, de 1989-98 (em toneladas/ano)

\begin{tabular}{lcccccccccc}
\hline & 1989 & 1990 & 1991 & 1992 & 1993 & 1994 & 1995 & 1996 & 1997 & 1998 \\
\hline Resina & 77857 & 61429 & 60714 & 79997 & 66596 & 84915 & 76787 & 74101 & 88036 & 88185 \\
Breu* & 54500 & 43000 & 42500 & 48000 & 40000 & 48000 & 43000 & 40000 & 49000 & 44000 \\
Terebintina & 11679 & 9214 & 9107 & 12000 & 9989 & 12737 & 11518 & 11115 & 13205 & 13228 \\
\hline
\end{tabular}

Fonte: Pesquisa do autor, 2001 (valores adaptados a partir de dados da Naval Stores Review, 1998).

*Fonte: Naval Stores Review, 1998.

Tabela 7. O mercado de resina no Brasil de 1992-98 (em toneladas/ano)

\begin{tabular}{lccccccc}
\hline & 1992 & 1993 & 1994 & 1995 & 1996 & 1997 & 1998 \\
\hline Produção* & 79997 & 66596 & 84915 & 76787 & 74101 & 88036 & 88185 \\
Exportação & 11426 & 9453 & 16344 & 15358 & 16958 & 18036 & 25328 \\
Importação & 0 & 0 & 0 & 0 & 704 & 929 & 1044 \\
Consumo* & 68571 & 57143 & 68571 & 61429 & 57847 & 70929 & 63901 \\
\hline
\end{tabular}

Fonte: Secretaria do Comércio Exterior, boletim do Banco do Brasil, 2001.(correspondência pessoal); *Fonte: Pesquisa do autor, 2001. (valores adaptados a partir de dados de Naval Stores Review, 1998). 
Tabela 8. O mercado de breu no Brasil de 1992-98 (em toneladas/ano)

\begin{tabular}{lccccccc}
\hline & 1992 & 1993 & 1994 & 1995 & 1996 & 1997 & 1998 \\
\hline Produção** & 48000 & 40000 & 48000 & 43000 & 40000 & 49000 & 44000 \\
Exportação & 10344 & 13512 & 15374 & 15367 & 16147 & 18566 & 25029 \\
Importação & 0 & 95 & 34 & 141 & 17 & 53 & 16 \\
Consumo* & 37656 & 26583 & 32660 & 27774 & 23870 & 30487 & 18987 \\
\hline
\end{tabular}

Fonte: Secretaria do Comércio Exterior, boletim do Banco do Brasil, 2001 (correspondência pessoal). *Fonte: Pesquisa do autor, 2001. (valores adaptados a partir de dados de Naval Stores Review, 1998).

**Fonte: Naval Stores Review, 1998.

Tabela 9. O mercado de terebintina no Brasil de 1992-98 (em toneladas/ano)

\begin{tabular}{lccccccc}
\hline & 1992 & 1993 & 1994 & 1995 & 1996 & 1997 & 1998 \\
\hline Produção* & 12000 & 9989 & 12737 & 11518 & 11115 & 13205 & 13228 \\
Exportação & 2536 & 3050 & 3835 & 4647 & 4790 & 6186 & 5677 \\
Importação & 0 & 0 & 1 & 2 & 16 & 34 & 24 \\
Consumo* & 9464 & 6939 & 8903 & 6873 & 6341 & 7053 & 7575
\end{tabular}

Fonte: Secretaria do Comércio Exterior, boletim do Banco do Brasil, 2001 (correspondência pessoal).

*Fonte: Pesquisa do autor, 2001. (valores adaptados a partir de dados de Naval Stores Review, 1998).

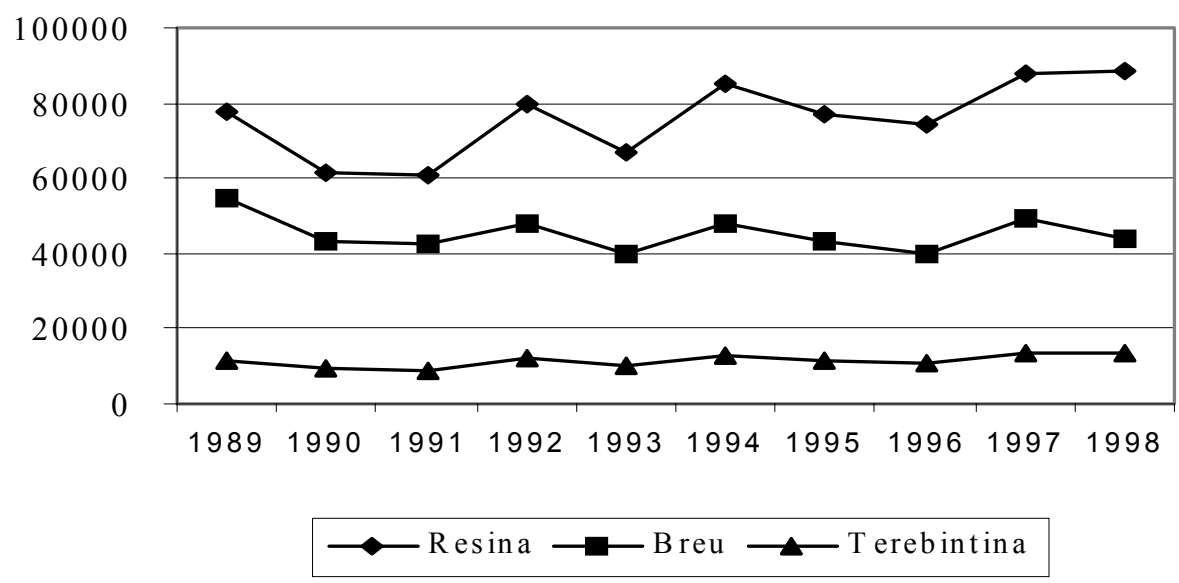

Figura 8 - Produções de resina, breu* e terebintina no Brasil de 1989-98 (em toneladas/ano)

Fonte: Pesquisa do autor, 2001 (valores adaptados a partir de dados da Naval Stores Review, 1998).

*Fonte: Naval Stores Review, 1998.

A produção dos produtos resinosos brasileiros aumenta gradualmente no período de 1989 a 1998. No entanto, este crescimento não é regular, verificando-se quedas bruscas nos anos 1990-91, 1993 e 1995, parcialmente explicadas por mudanças de políticas no país transtornando os preços dos produtos. 


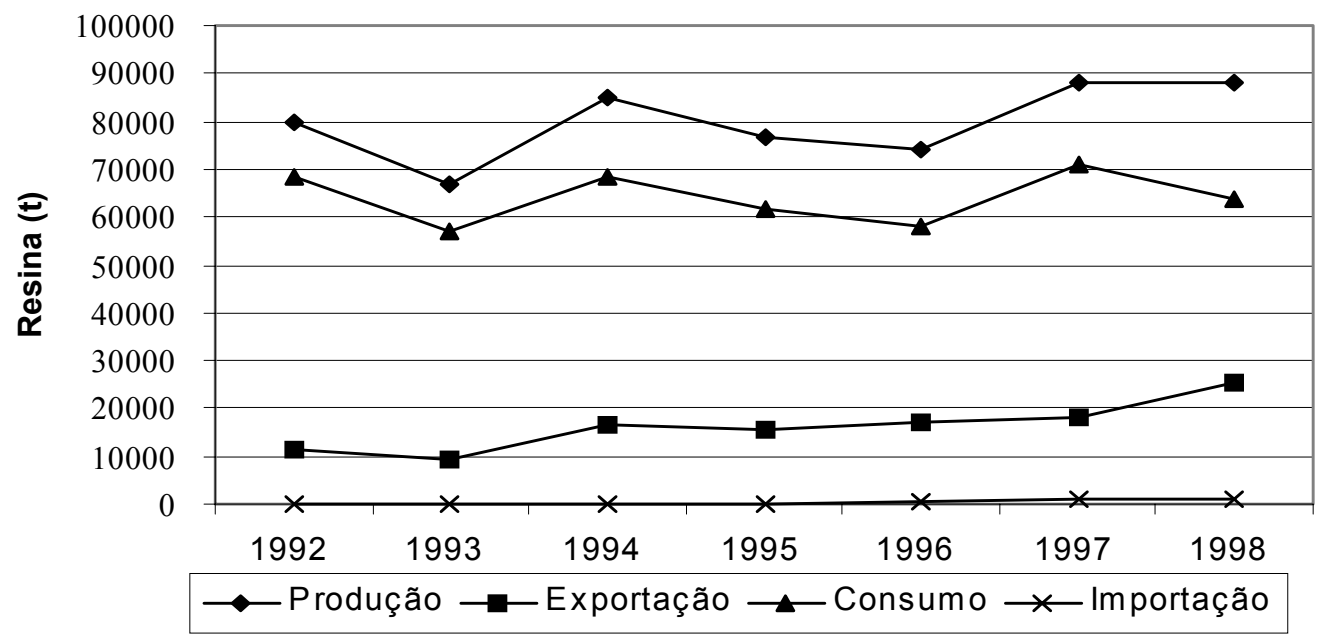

Figura 9 - Produção*, exportação, importação e consumo* de resina no Brasil, 1992-98 (em toneladas/ano)

Fonte: Secretaria do Comércio Exterior, boletim do Banco do Brasil, 2001.(correspondência pessoal); *Fonte: Pesquisa do autor, 2001. (valores adaptados a partir de dados de Naval Stores Review, 1998).

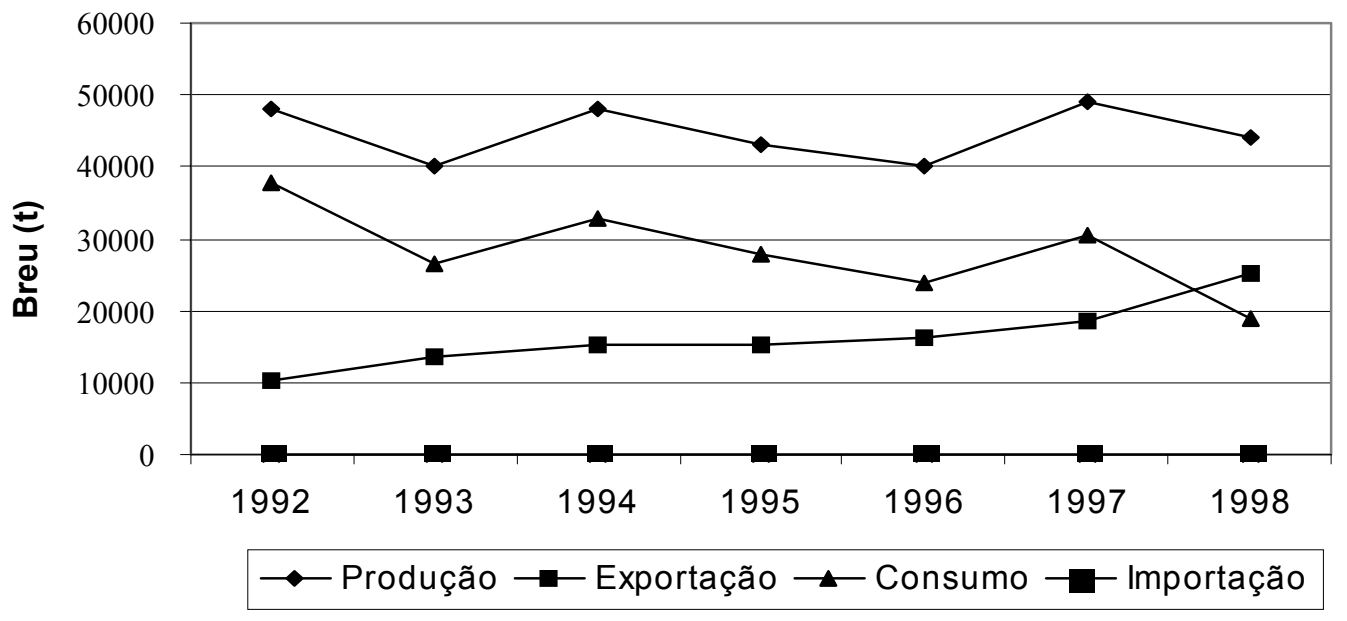

Figura 10 - Produção**, exportação, importação e consumo* de breu no Brasil, 1992-98 (em toneladas /ano).

Fonte: Secretaria do Comércio Exterior, boletim do Banco do Brasil, 2001 (correspondência pessoal). *Fonte: Pesquisa do autor, 2001. (valores adaptados a partir de dados de Naval Stores Review, 1998).

**Fonte: Naval Stores Review, 1998. 


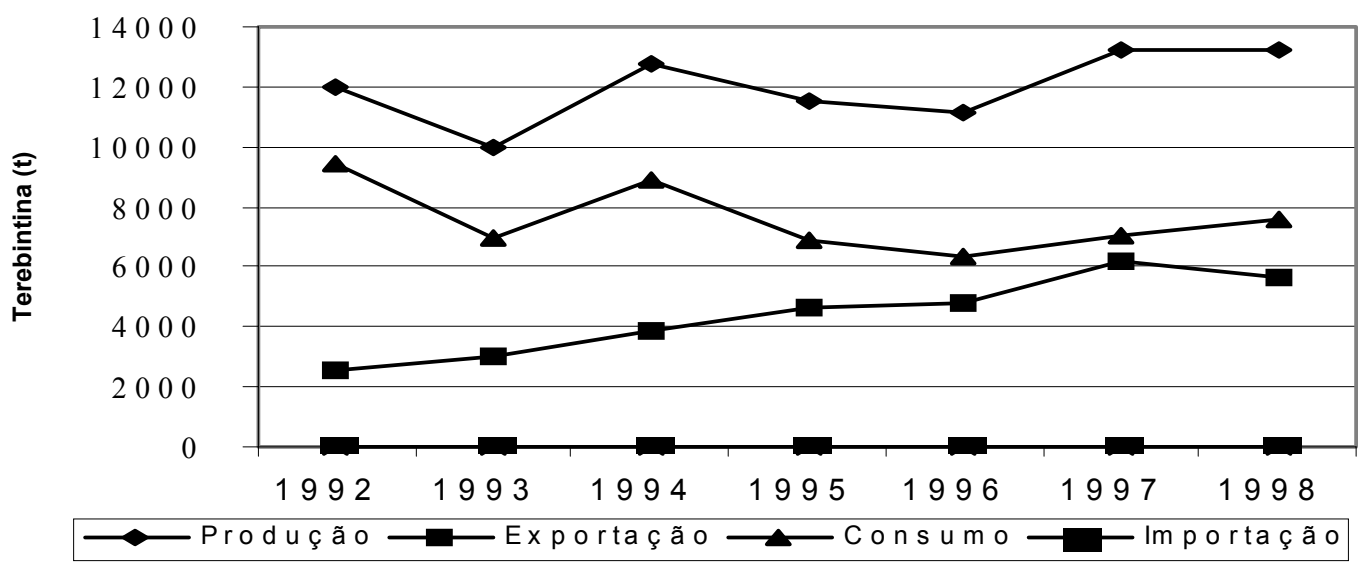

Figura 11 - Produção*, exportação, importação e consumo* de terebintina no Brasil, 1992-98

(em toneladas/ano)

Fonte: Secretaria do Comércio Exterior, boletim do Banco do Brasil, 2001 (correspondência pessoal). *Fonte: Pesquisa do autor, 2001. (valores adaptados a partir de dados de Naval Stores Review, 1998).

Como se pode observar nas figuras anteriores, a quantidade importada de produtos resinosos no Brasil é insignificante quando comparada às exportações. Estas últimas vêm crescendo desde 1992 a ritmos bastante elevados contribuindo positivamente para o saldo da balança comercial brasileira.

Pode-se observar pelas figuras anteriores que os valores do consumo brasileiro de produtos resinosos superam as suas exportações. Uma vez que, processando a resina ou o breu, estão-se realizando operações industriais que acrescentam valor ao produto dentro do território brasileiro e que de outro modo teria de ser importado.

O consumo de produtos resinosos no Brasil está relativamente estabilizado, indicando que é exportado sobretudo o excedente das produções. No caso do breu, a partir de 1997 , verifica-se uma diminuição significativa do consumo brasileiro acarretando um aumento contínuo das exportações. 


\subsubsection{Produção e tendências Mundiais}

À semelhança de muitos produtos agrícolas e agro-industriais, também no setor dos produtos resinosos o Brasil atingiu uma posição de destaque nas produções mundiais. Atualmente disputa as primeiras posições entre os maiores produtores mundiais de resina e seus derivados, enfrentando o domínio de produção e comércio da República Popular da China e Indonésia (vide Tabela 10).

Tabela 10. Produção de goma-resina dos principais países produtores, de 1988 a 1998 (em toneladas/ano)

\begin{tabular}{lccccccccccc}
\hline & 1988 & 1989 & 1990 & 1991 & 1992 & 1993 & 1994 & 1995 & 1996 & 1997 & 1998 \\
\hline Portugal & 75759 & 38548 & 48680 & 31808 & 21553 & 17000 & 27500 & 28750 & 32500 & 30000 & 25000 \\
México & 40500 & 27300 & 39000 & 33000 & 40000 & 42000 & na & 30000 & 33000 & 34000 & na \\
Índia & na & na & na & 29800 & 29000 & 35000 & 40000 & 37000 & 41500 & 41300 & 34000 \\
Brasil* & na & 77857 & 61429 & 60714 & 79997 & 66596 & 84915 & 76787 & 74101 & 88036 & 88185 \\
Indonésia & 41333 & 52000 & 55333 & 65333 & 73333 & 92000 & 96000 & 71067 & 73333 & 91948 & 64000 \\
China & na & 566667 & 534667 & 520000 & 558667 & 580000 & 500000 & 512667 & 533333 & 706667 & 506667 \\
\hline TOTAL & 157592 & 757181 & 735013 & 736608 & 786553 & 819333 & 740200 & 750607 & 783800 & 987208 & 713433
\end{tabular}

Fonte: Naval Stores Review, Internacional yearbook 1998.

*Fonte: Pesquisa do autor, 2000 (valores adaptados a partir de dados de Naval Stores Review, 1998).

Tabela 11. Produção de breu dos principais países produtores, de 1989 a 1998 (em toneladas/ano)

\begin{tabular}{lcccccccccc}
\hline & 1989 & 1990 & 1991 & 1992 & 1993 & 1994 & 1995 & 1996 & 1997 & 1998 \\
\hline Portugal & 30838 & 38944 & 25446 & 17242 & 13600 & 22000 & 23000 & 26000 & 24000 & 20000 \\
México & 39000 & 27300 & 23100 & 28000 & 29400 & 20600 & 21000 & 23100 & 23805 & 24500 \\
Índia & 25000 & 25000 & 25300 & 26600 & 33200 & 42500 & 38700 & 42700 & 43300 & 24500 \\
Brasil & 54500 & 43000 & 42500 & 48000 & 40000 & 48000 & 43000 & 40000 & 49000 & 44000 \\
Indonésia & 39000 & 41500 & 49000 & 55000 & 69000 & 72000 & 53300 & 55000 & 68961 & 48000 \\
China & 380000 & 530000 & 400000 & 384500 & 375000 & 435000 & 419000 & 390000 & 401000 & 425000 \\
\hline
\end{tabular}

Fonte: Naval Stores Review, Internacional yearbook, 1998.

As tendências mundiais do setor de produtos resinosos estão diretamente relacionadas com as tendências do líder mundial, a República Popular da China. Este país, por se tratar de uma economia de regime político bastante fechado, não disponibiliza muitas informações para as demais economias capitalistas. A história tem indicado, de um modo geral, os poucos resultados 
econômicos das economias comunistas, como são o caso da ex-URSS, e Alemanha do Leste, entre outras. Mas a China parece ser a exceção que confirma a regra, realizando uma progressiva abertura ao mundo ocidental, e atingindo níveis de crescimento excepcionais. As suas potencialidades no campo dos produtos resinosos são enormes, de modo que as tendências gerais são de crescimento da produção e participação no comércio mundial.

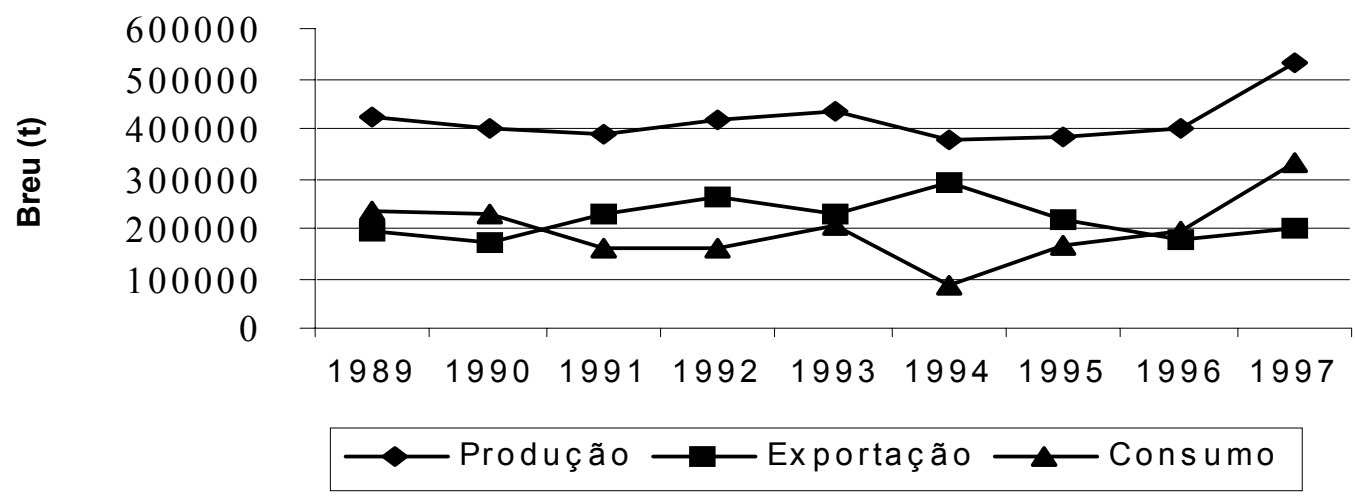

Figura 12 - Produção, exportação e consumo de breu na China, de 1989-97 (em toneladas/ano) Fonte: Naval Stores Review, International yearbook,1998.

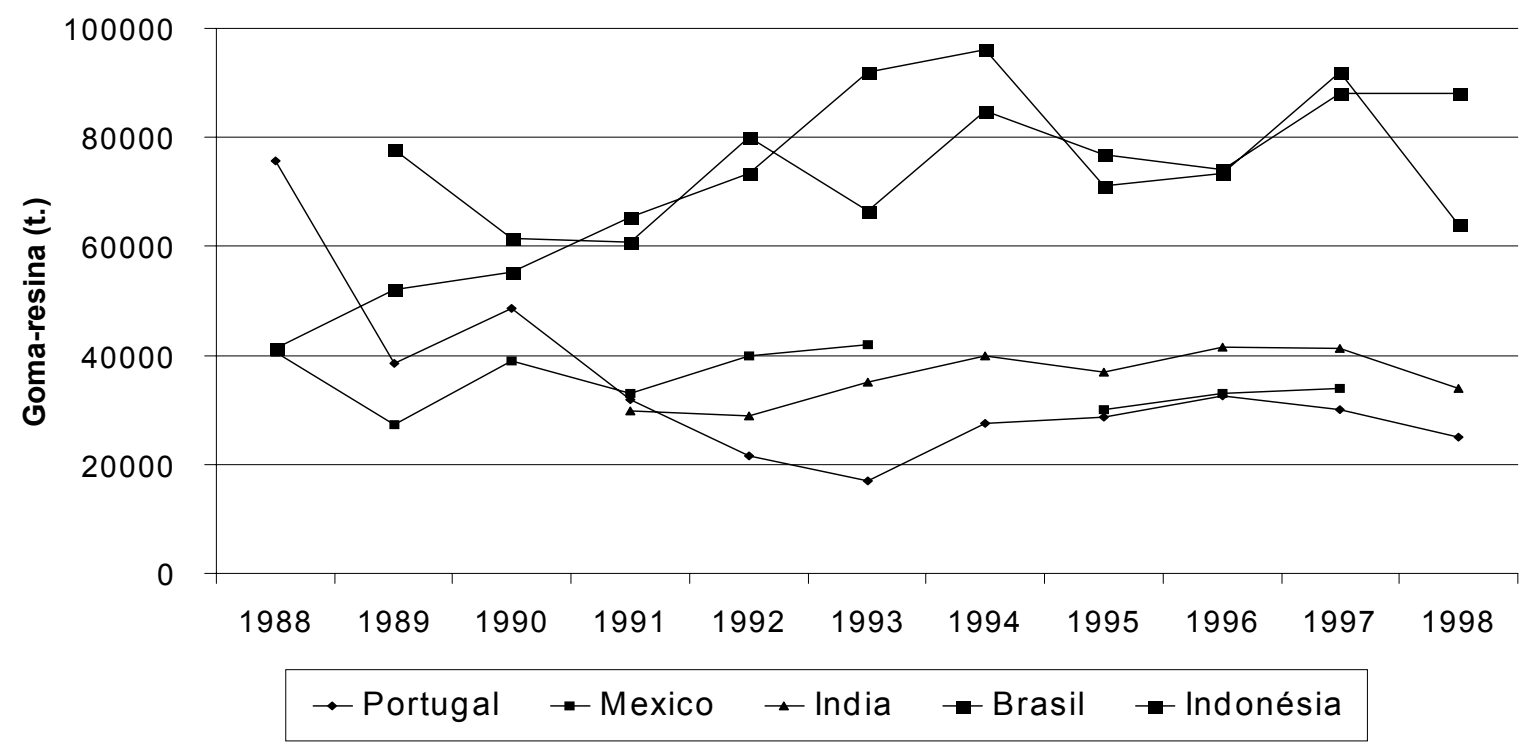

Figura 13 - Produção de resina pelos principais produtores mundiais, excluindo a China, de 1988-98 (em toneladas/ano)

Fonte: Naval Stores Review, International yearbook,1998. 


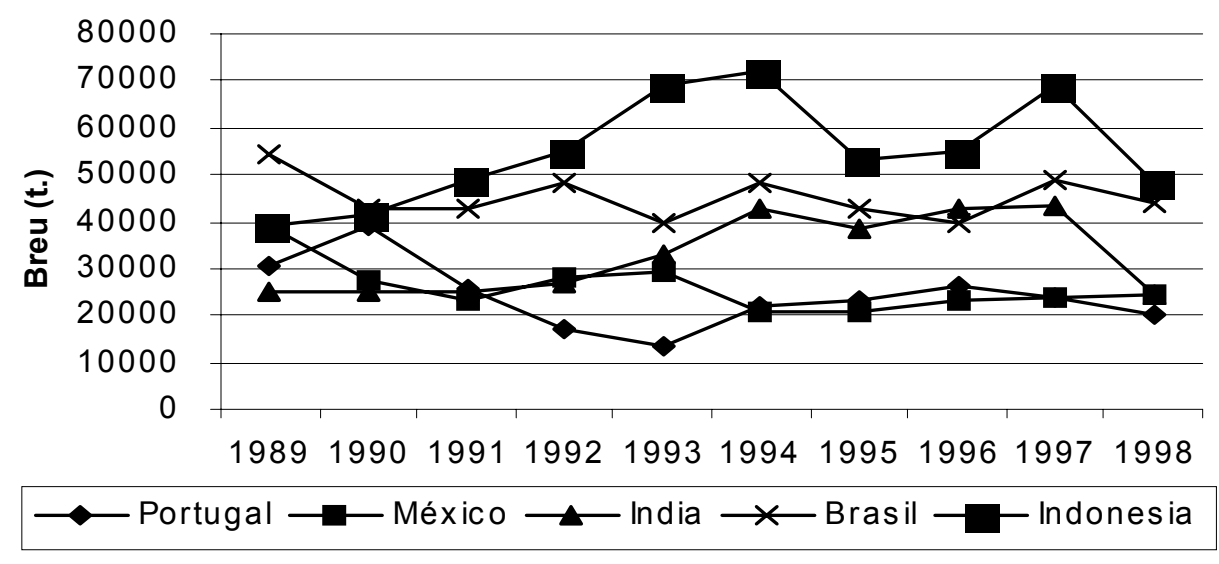

Figura 14 - Produção de breu pelos principais países produtores, excluindo a China, 1989-98 (em toneladas/ano)

Fonte: Naval Stores Review, International yearbook,1998.

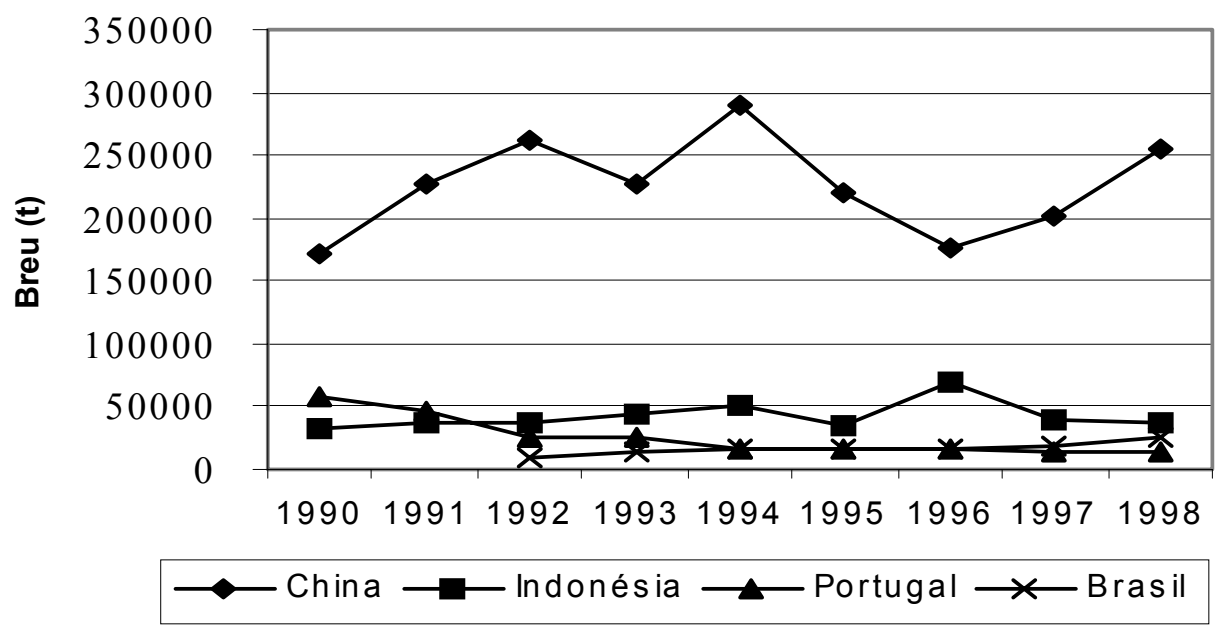

Figura 15 - Exportação de breu pelos principais exportadores mundiais, de 1990 a 1998 (em toneladas /ano).

Fonte: Naval Stores Review, International yearbook,1998.

Observando as figuras anteriores (Figura 13, 14 e 15), pode-se verificar a evolução das produções de goma-resina e breu e as exportações de breu pelos principais países produtores mundiais, excluindo a China, que lidera destacada na produção e comercialização de goma- 
resina e seus derivados, para um melhor entendimento das figuras. Assim, constata-se que a Indonésia é o principal concorrente atual do Brasil em produção e exportações de goma-resina e breu. Outros concorrentes como a Índia, o México e Portugal, apresentaram-se, no início da década ou em alguns anos particulares, a um nível similar de produção e comercialização dos produtos resinosos mas com médias de produção menos competitivas.

De um modo geral, quer a produção, quer a comercialização dos produtos resinosos apresentaram variações fortes em todos os países indicando vulnerabilidade do mercado a nível mundial.

Os trabalhos de Ferreira (1993) e Leite \& Morais (1990) oferecem detalhes da experiência portuguesa. Este país chegou a ser o maior produtor mundial nos anos 30 e 40, não deixando, desde então, de se manter entre os líderes. A título de curiosidade, de 1982 a 1987, a matéria-prima consumida pela indústria portuguesa oscilou próximo das 90 a 105 mil toneladas anuais. Em 1988, Portugal exportou 84 mil toneladas de produtos resinosos no valor de 63 milhões de USD. A partir de 1987, o ritmo de redução da produção acelerou-se e o país, que chegou a produzir 105.000 toneladas anuais de goma-resina, e ser o primeiro produtor mundial por vários anos, não ultrapassa hoje as 25.000 toneladas por ano.

A partir de 1993, além da entrada maciça da China no mercado mundial, a elevação dos custos de mão-de-obra acentuou-se e ameaça inviabilizar a resinagem em Portugal, como já aconteceu com a França na década de 60, e com os Estados Unidos na década de 30, outrora lideres em produção mundial.

Os Estados Unidos da América, no princípio do século, era o país que mais se destacava como produtor mundial de goma-resina. Posteriormente diminuiu drasticamente as suas produções devido ao aumento do custo da sua mão-de-obra e diminuição das suas florestas de Pinus. Atualmente obtém breu e a terebintina (em grandes quantidades) através da resina de tall oil. 


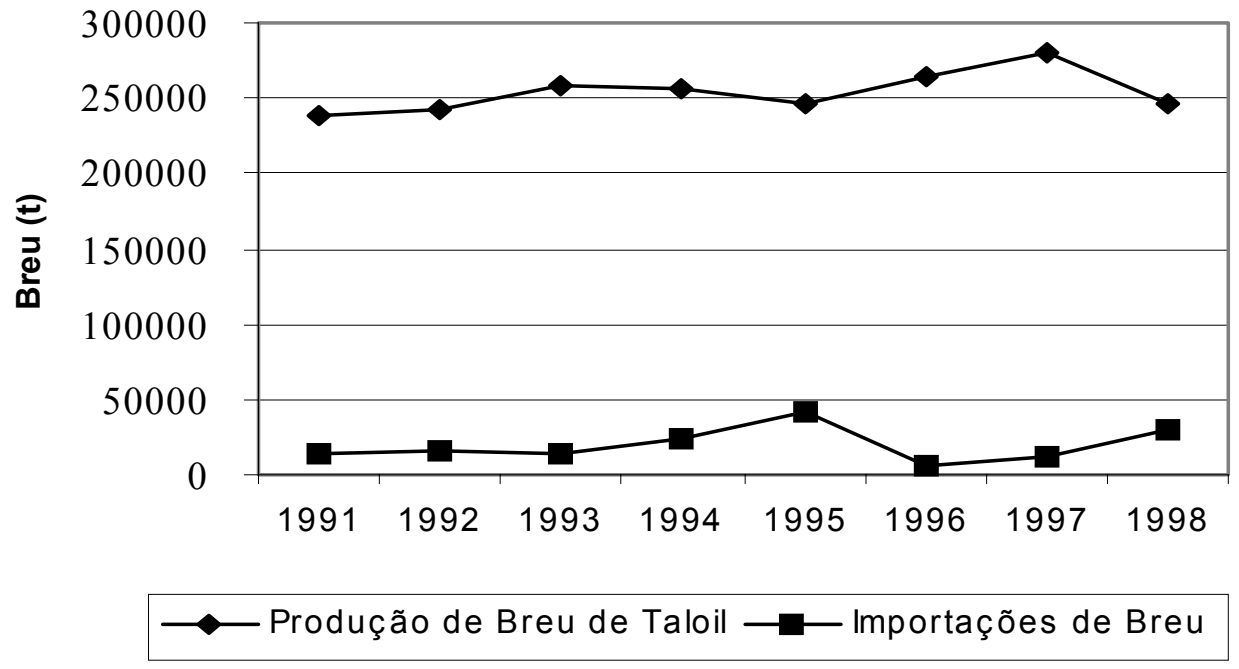

Figura 16 - Produção de breu de tall oil e importação do similar de origem na goma-resina nos EUA, de 1991-98 (em toneladas/ano)

Fonte: Naval Stores Review, International yearbook,1998.

Segundo Naval Stores Market analisys, 1998, recentemente alguns países asiáticos, nomeadamente o Vietnã e a Coréia do Norte, por possuírem grandes áreas de floresta de Pinus e mão-de-obra disponível, vêm apresentando relativos crescimentos da produção de produtos resinosos apesar de ainda apresentarem bastante irregularidade na produção e qualidade dos seus produtos.

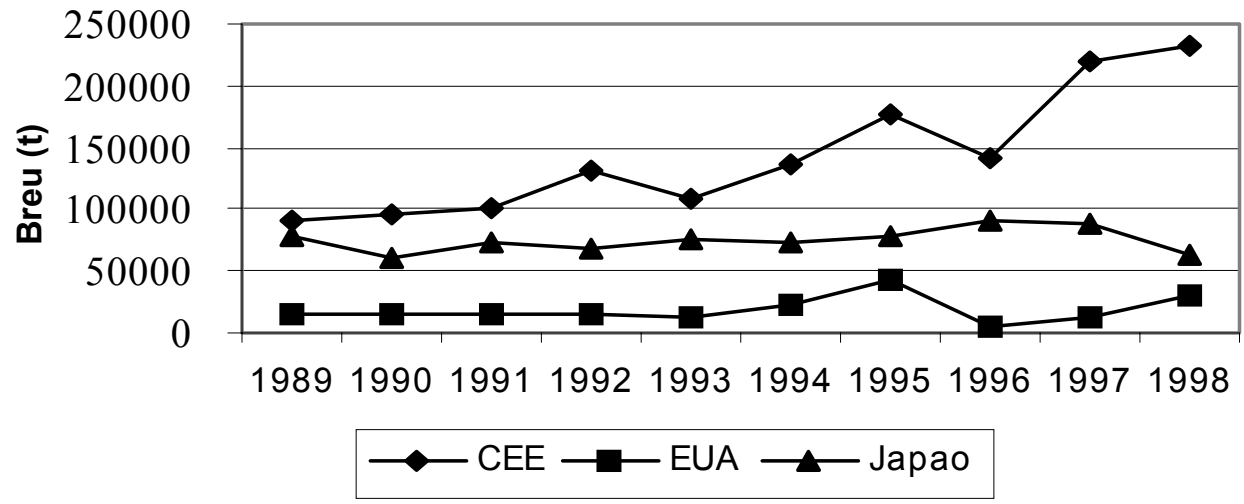

Figura 17 - Principais importadores mundiais de breu, de 1989-98 (em toneladas/ano) Fonte: Naval Stores Review, International yearbook,1998. 
Tabela 12. Valores de produção e comércio mundial de breu e terebintina (1000 t.)

\begin{tabular}{|c|c|c|c|c|c|c|c|c|c|c|}
\hline \multirow[t]{2}{*}{ Região/País } & \multirow[t]{2}{*}{ Ano } & \multirow[t]{2}{*}{ Fonte } & \multicolumn{4}{|c|}{ BREU } & \multicolumn{4}{|c|}{ TEREBINTINA } \\
\hline & & & Prod. & Exp. & Imp. & Cons. & Prod. & Exp. & Imp. & Cons. \\
\hline ÁSIA & & & 477 & 178 & 2 & 300 & 58 & 6 & 4 & 56 \\
\hline China & 1996 & G & 370 & 176 & 0 & 194 & 43 & 6 & 0 & 37 \\
\hline Índia & 1996 & $\mathrm{G}$ & 25 & 0 & 2 & 27 & 6 & 0 & 4 & 10 \\
\hline Rússia & 1992 & $\mathrm{G}, \mathrm{P}, \mathrm{W}$ & 80 & 1 & -- & 79 & 9 & 0 & 0 & 9 \\
\hline Vietnã & 1990 & $\mathrm{G}, \mathrm{W}$ & 2 & 1 & 0 & 1 & 0 & 0 & 0 & 0 \\
\hline OCEANIA & & & 76 & 36 & 98 & 138 & 16 & 9 & 9 & 15 \\
\hline Austrália & 1995 & $\mathrm{P}$ & 4 & 7 & 0 & 11 & 2 & 1 & 0 & -- \\
\hline Indonésia & 1996 & G & 55 & 35 & 0 & 20 & 10 & 7 & 0 & 3 \\
\hline Japão & 1996 & $\mathrm{P}$ & 16 & 0 & 91 & 107 & -- & 0 & 7 & 7 \\
\hline EUROPA & & & 112 & 33 & 170 & 221 & 30 & 6 & 11 & 38 \\
\hline Finlândia & 1996 & $P$ & 26 & 4 & 0 & 21 & 14 & 0 & 0 & 14 \\
\hline França & 1993 & $P$ & 7 & -- & 22 & 17 & -- & 0 & 0 & 3 \\
\hline Alemanha & 1996 & -- & 0 & 0 & 50 & 50 & 0 & 0 & 1 & 1 \\
\hline Grécia & 1996 & G & 6 & 2 & 0 & 4 & 2 & 0 & 0 & 2 \\
\hline Itália & 1996 & -- & 0 & 9 & 19 & 10 & 0 & 1 & 1 & 0 \\
\hline Holanda & 1996 & -- & 0 & 1 & 45 & 43 & 0 & 0 & 0 & 0 \\
\hline Portugal & 1995 & G & 17 & 16 & 7 & 8 & 4 & 5 & 2 & 1 \\
\hline Espanha & 1994 & G & 2 & 1 & 16 & 17 & 0 & 0 & 5 & 5 \\
\hline Suécia & 1995 & $\mathrm{P}$ & 26 & -- & 0 & 26 & 10 & -- & 0 & 10 \\
\hline Reino Unido & 1995 & $\mathrm{P}$ & 9 & 0 & 9 & 18 & -- & 0 & 3 & 3 \\
\hline AMÉRICA DO NORTE & & & 305 & 41 & 22 & 286 & 103 & 13 & 10 & 107 \\
\hline Canadá & 1996 & $\mathrm{P}$ & 5 & 6 & 8 & 7 & -- & 7 & 0 & -- \\
\hline EUA & 1996 & $\mathrm{P}, \mathrm{G}, \mathrm{W}$ & 300 & 35 & 14 & 279 & 103 & 6 & 10 & 107 \\
\hline AMÉRICA LATINA & & & 123 & 37 & 4 & 63 & 22 & 9 & 1 & 17 \\
\hline Argentina & 1992 & G & 21 & 13 & 0 & 8 & 4 & 1 & 0 & 4 \\
\hline Brasil & 1996 & G & 40 & 16 & 0 & 23 & 11 & 4 & 0 & 6 \\
\hline Honduras & 1992 & G & 6 & 5 & 0 & 1 & 1 & 1 & 0 & 1 \\
\hline México & 1996 & G & 23 & 0 & 0 & 23 & 5 & 0 & 0 & 5 \\
\hline ÁFRICA DO SUL & 1993 & $\mathrm{P}$ & 2 & 0 & 4 & 5 & 1 & 0 & 0 & -- \\
\hline MUNDO & & & 1093 & 319 & 299 & 967 & 229 & 38 & 35 & 232 \\
\hline
\end{tabular}

Nota: $\mathrm{G}$ - breu de goma-resina; $\mathrm{P}$ - breu de tall oil; $\mathrm{W}$ - breu de madeira.

Fonte: Naval Stores review Internacional Yearbook, 1998.

Observando os grandes importadores (consumidores) mundiais, pode-se dividir o mundo em três partes ou grande mercados consumidores: a Comunidade Européia, o Japão e os Estados Unidos da América. Analisando os demais exportadores, à parte o poderio da China, pode-se constatar que o Japão é importador principalmente da Indonésia e de outros países emergentes asiáticos; que os EUA são auto-sustentados por produções próprias de resina de tall oil; e que a Comunidade Européia se abastece com exportações do Brasil, de Portugal e parte da Indonésia. 
Deste modo, observando o panorama global, considera-se que o Brasil tem potencialidades de crescimento mas somente até um certo nível uma vez que a China domina e seu poderio parece continuar.

\subsubsection{Os preços dos produtos resinosos}

Os produtos resinosos são considerados commodities agro-industriais e deste modo o que vai reger os seus mercados vão ser seus preços mais do que propriamente a qualidade dos seus produtos. No caso dos produtos resinosos brasileiros é interessante verificar como os preços se comportam ao longo dos tempos. Para isso, é necessário encontrar séries de preços longas e verdadeiras.

A Fundação Florestal do Estado de São Paulo apresenta para o período de 1990 a 1997, uma série de preços de goma-resina (Florestar Estatístico, 1997) com base em dados da ARESB, mas que possuem poucas informações quanto à metodologia de coleta de informações.

Outra série já obtida a partir de informações oferecidas pela Associação dos Resinadores do Brasil, Harima do Brasil, e Fundação Florestal, para o período de 1984 a 1997, pode ser encontrada no manual técnico de resinagem de Garrido et al. (1998).

A série mais completa encontrada é a série de preços de goma-resina posto floresta fornecida pela ARESB (1999) apresentando dados mensais completos desde Janeiro de 1984 até Outubro de 1998. Esta série de preços, observada na Figura 18, parece evidenciar uma tendência de alta até 1997, diminuindo em 1998. A ausência de informações sobre o método de coleta dos dados e a busca de mais evidências que expliquem as tendências encontradas para os diferentes períodos justificam uma investigação mais detalhada proposta neste trabalho.

Relativamente aos valores de preços dos derivados e dos produtos no mercado externo, não foram encontrados dados para os períodos desejados, prejudicando a pesquisa sobre causalidade e transmissão de preços que se tinham objetivado anteriormente. Aguardam-se novas séries de dados mais completas e longas. 


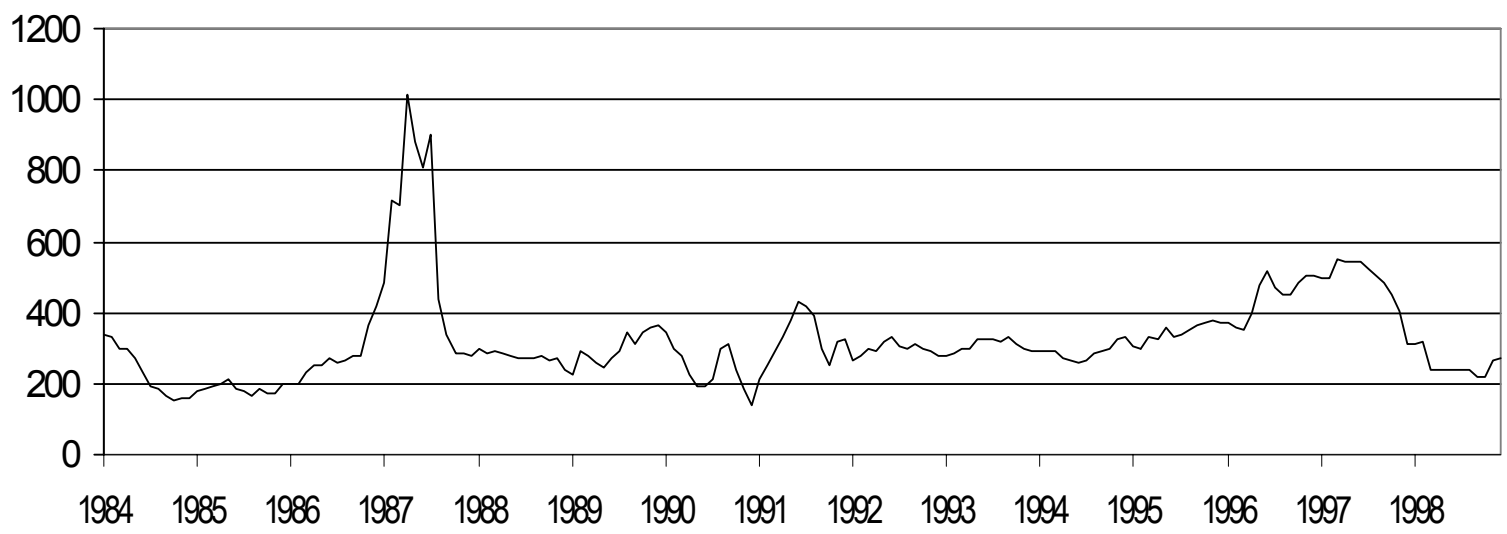

Figura 18 - Evolução dos preços mensais da goma-resina, de Jan. 1984 a Out. 1998 (em US\$/tonelada).

Fonte: ARESB, 1999 (correspondência pessoal)

No entanto, por meio de dados fornecidos por empresas do setor, foi possível estabelecer alguns padrões e sobretudo verificar o aumento de valor agregado que acontece através do processamento da resina. Para os muitos derivados de breu e terebintina, sabe-se que existem produtos de valores $300 \%$ mais elevados, ou seja, valores rondando US\$2000,00 por Tonelada.

Observando o comportamento dos preços da resina, breu e terebintina, no Brasil, constata-se comportamentos semelhantes para os preços da resina e do breu. Ou seja, um aumento no preço da resina reflete um aumento no preço do breu ou vice versa. Já no caso da terebintina é difícil estabelecer um padrão de comportamento, já que, segundo informações da ARESB (1999), os seus preços sempre variaram muito. 


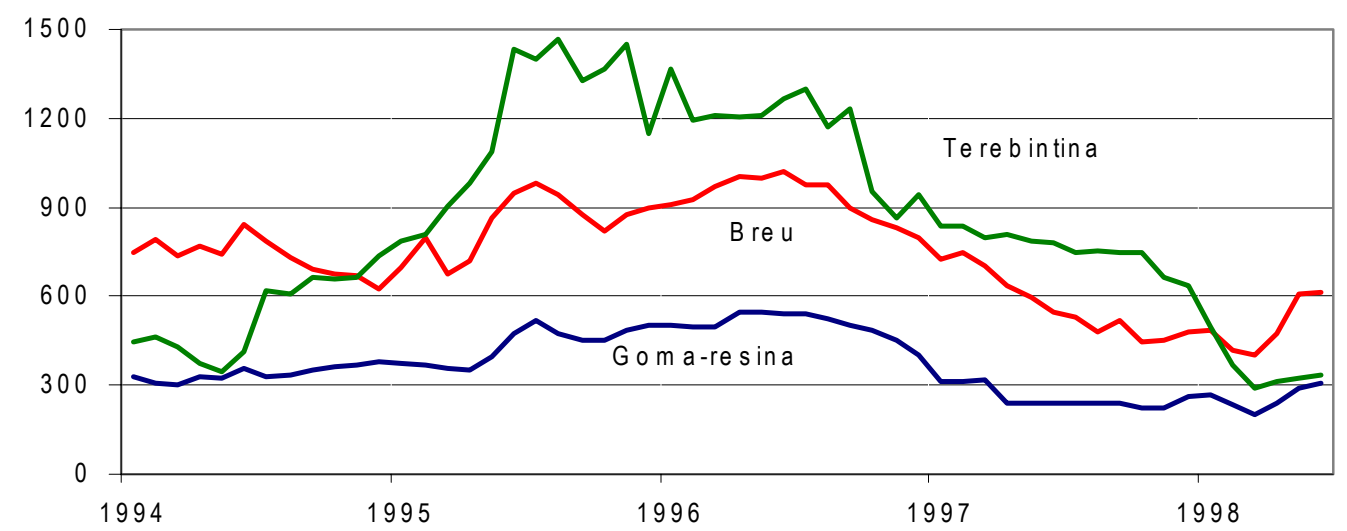

Figura 19 - Evolução dos preços médios mensais de resina, breu e terebintina no mercado interno, de Dez. 1994 a Abr. 1998 (em R\$/tonelada).

Fonte: ARESB, 1999 (correspondência pessoal), e empresas do setor segundo pesquisa do autor, 1998.

Tabela 13. Preços médios anuais de resina, breu e terebintina de exportação, de 1992 a 2000 (em US\$ FOB/tonelada).

\begin{tabular}{lccccccccc}
\hline & 1992 & 1993 & 1994 & 1995 & 1996 & 1997 & 1998 & 1999 & 2000 \\
\hline Resina & 402 & 648 & 416 & 506 & 624 & 731 & 526 & 445 & 385 \\
Breu & 644 & 652 & 658 & 717 & 784 & 825 & 622 & 549 & 509 \\
Terebintina & 538 & 510 & 498 & 504 & 903 & 1097 & 833 & 445 & 369 \\
\hline
\end{tabular}

Fonte: Secretaria do Comercio Exterior, boletim do Banco do Brasil, 2001 (correspondência pessoal).

Relativamente ao preço dos produtos resinosos exportados, segundo a Figura 20, o comportamento apresentado é semelhante ao do mercado interno. Verificam-se variações quase simultâneas nos preços da resina e do breu e variações acentuadas no valor da terebintina. Apesar das diferentes moedas pode-se constatar preços substancialmente mais elevados no mercado externo do que no mercado interno.

Considerando o mercado nacional e o mercado mundial, sabe-se que um dos fatores que mais prejudica a entrada dos produtos brasileiros no mercado exterior são os preços dos produtos similares no estrangeiro, mais precisamente os praticados pelos concorrentes diretos, como, por exemplo, a Indonésia e a China. 


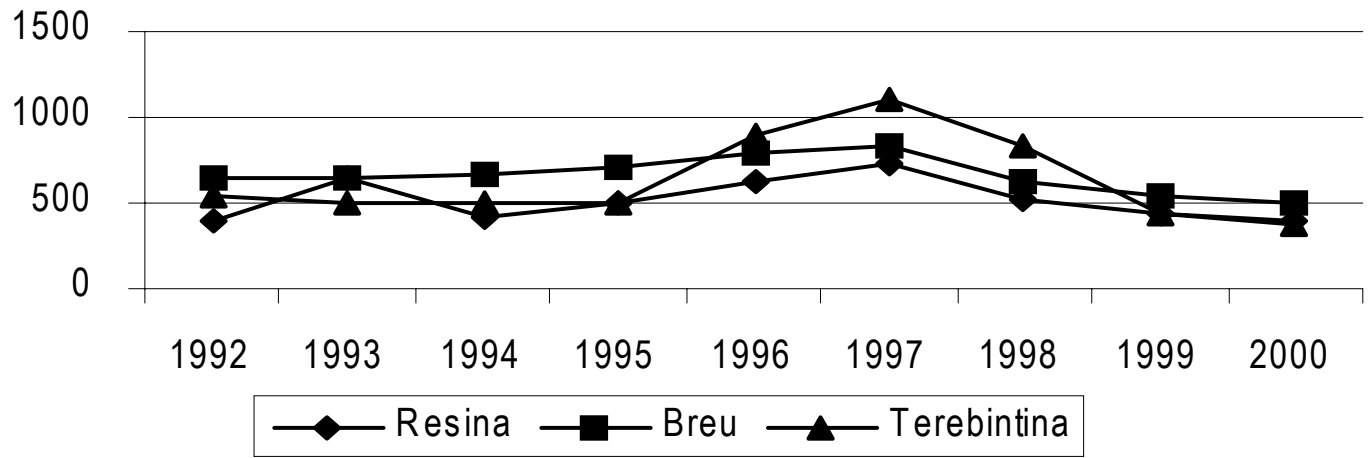

Figura 20 - Evolução dos preços dos produtos resinosos de exportação no Brasil, de 1992 a 2000 (em US\$ FOB/tonelada)

Fonte: Secretaria do Comercio Exterior, boletim do Banco do Brasil, 2001 (correspondência pessoal).

Através da Tabela 14 é observável a dificuldade dos produtos resinosos brasileiros no exterior. Os seus preços são sempre ameaçados pelos preços da China e Indonésia, e, em parte, pelos produtos portugueses que, apesar de possuírem maiores preços, são procurados por algumas características específicas da sua resina.

Tabela 14. Preços médios anuais de breu para exportação, de 1991 a 1995 (em US\$ FOB/tonelada).

\begin{tabular}{lccccc}
\hline & 1991 & 1992 & 1993 & 1994 & 1995 \\
\hline Brasil & 680 & 680 & 600 & 590 & $775-850$ \\
Portugal & 800 & 765 & 795 & 835 & 900 \\
China & 675 & 675 & 650 & 575 & $750-775$ \\
Indonésia & 570 & 620 & 575 & 560 & $650-670$ \\
\hline
\end{tabular}

Nota: O breu especificado é do tipo WW.

Fonte: Koppen \& Hone (1995).

A produção de resina brasileira, por representar uma percentagem ainda pouco significativa da produção mundial, não vai ter influência nos preços dos seus derivados. É a República Popular da China que responde por cerca de $65 \%$ da produção mundial, que vai ter elevada influência nos preços praticados pelos outros países produtores de importância e quem vai ditar os patamares de preços dos produtos resinosos. 
Como caso ilustrativo da influência chinesa, segundo Koppen \& Hone (1995), pode-se referir que no ano de 1995, os preços internacionais dos produtos resinosos atingiram patamares muito elevados. Este fato veio decorrente de severas inundações ocorridas no continente asiático, que provocaram uma redução drástica da matéria-prima chinesa. Essa variação também foi notada no Brasil e é facilmente percebível nas Figuras 19 e 20, ou seja, nos preços do mercado interno e externo.

\subsubsection{Importância do setor}

Segundo dados da ABIQUIM (1999), o setor químico em geral investiu cerca de 1 bilhão de US\$ por ano, nos últimos cinco anos, mas o déficit da sua balança comercial ainda é alto, rondando em 1999 os US\$ 6,4 bilhões. Segundo esta associação, poderiam ocorrer maiores investimentos no setor se houvesse boas perspectivas econômicas, estabilidade de regras e, consequentemente, expectativas favoráveis quanto à rentabilidade dos empreendimentos no país.

O faturamento líquido do setor químico brasileiro atingiu cerca de US\$ 43 bilhões em 1998, sendo aproximadamente $43 \%$ originários de produtos químicos de uso industrial. É dentro deste item que os produtos resinosos se inserem. Este valor corresponde a um faturamento bruto de US\$ 53 bilhões.

Tabela 15. Distribuição do faturamento da indústria química brasileira, 1998

\begin{tabular}{lc}
\hline Setor & US\$ bilhões \\
\hline Produtos químicos de uso industrial & 18,5 \\
Sabões e detergentes & 2,2 \\
Adubos e fertilizantes & 2,9 \\
Defensivos agrícolas & 2,6 \\
Tintas, esmaltes e vernizes & 2,0 \\
Higiene pessoal, perfumaria e cosméticos & 4,1 \\
Fibras artificiais e sintéticas & 1,5 \\
Farmacêuticos & 8,2 \\
Óleos essenciais, aromas, fragrâncias etc. & 0,6 \\
Total & 42,6 \\
\hline
\end{tabular}

Fonte: ABIQUIM, 1999. 
Relativamente ao setor dos produtos resinosos brasileiros, verifica-se que abastece vários itens mencionados na Tabela 15, tais como, produtos químicos de uso industrial, sabões e detergentes, tintas, esmaltes, vernizes, perfumaria, aromas e fragrâncias entre outros. Apesar do faturamento do setor ser de valores inferiores aos acima mencionados contribui positivamente para o saldo da balança comercial brasileira e tem potencialidades de crescer e atingir a médio prazo valores muito superiores.

Estima-se que os valores totais faturados de produtos resinosos, no Brasil, se aproximaram dos 120 milhões de dólares em 1997, dos quais, parte são exportados e os restantes consumidos e processados dentro do país.

Tabela 16. Valor das exportações de produtos resinosos no Brasil, de 1992 a 2000 (em 1000 US\$ FOB/ano).

\begin{tabular}{lccccccccc}
\hline & 1992 & 1993 & 1994 & 1995 & 1996 & 1997 & 1998 & 1999 & 2000 \\
\hline Resina & 4591 & 6130 & 6796 & 7775 & 10583 & 13189 & 13318 & 6402 & 3141 \\
Breu & 6660 & 8804 & 10123 & 11018 & 12658 & 15315 & 15580 & 17029 & 14697 \\
Terebintina & 1365 & 1554 & 1908 & 2342 & 4327 & 6785 & 4728 & 3121 & 3069 \\
TOTAL & 12616 & 16488 & 18826 & 21135 & 27568 & 35289 & 33626 & 26551 & 20907 \\
\hline
\end{tabular}

Fonte: Secretaria do Comercio Exterior, boletim do Banco do Brasil, 2001 (correspondência pessoal).

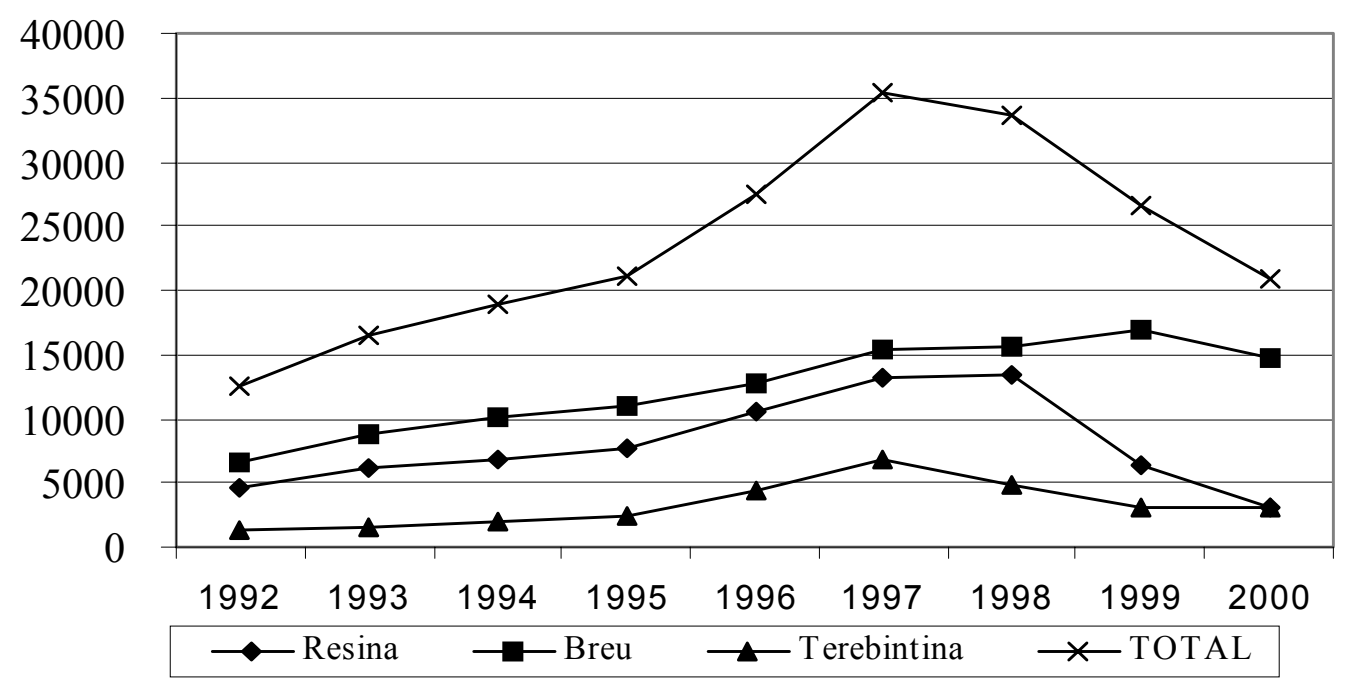

Figura 21 - Valor das exportação dos produtos resinosos no Brasil, 1992-00 (em 1000 US\$FOB/ano)

Fonte: Secretaria do Comercio Exterior, boletim do Banco do Brasil, 2001 (correspondência pessoal). 
Analisando os valores exportados, verifica-se crescimento em quantidade e valor total nos três produtos resinosos considerados de 1992 a 1998. A partir de 1998, as exportações de goma-resina diminuíram significativamente, aparentemente devido a uma diminuição da quantidade produzida, e de igual modo mas sendo menos significativos o breu e a terebintina, devido à diminuição da sua matéria prima.

Finalmente, o setor também é importante empregador de mão-de-obra, empregando diretamente um total próximo de 14.000 pessoas, das quais aproximadamente 12.000 se encontram ligadas à coleta da resina nas florestas e 2.000 à indústria de processamento. Considerando-se a mão-de-obra indireta, o número de pessoas beneficiadas com este setor sobe para mais de 22.000 .

O Brasil possui um bom nível industrial na transformação dos produtos resinosos, breu e terebintina, mas certamente o produto brasileiro possui dificuldade de acesso no mercado mundial, via competição de preços com o maior produtor mundial, a China.

\subsubsection{Problemas do setor}

De acordo com representantes do setor $\mathrm{IPEF}^{8}$, e pesquisa do autor, 2000, podem-se observar dois grupos de problemas que afetam o setor, os problemas associados ao mercado interno e os problemas associados ao mercado externo. Os problemas associados com o mercado interno podem ser resumidos nos seguintes pontos:

- Previsão de diminuição das áreas de exploração de resina;

- Previsão de crescimento dos custos de produção;

- Falta de incentivos por parte do governo;

- Concorrência com resinas sintéticas e tall oil;

- Poucos esforços em P\&D e baixa assimilação da tecnologia já existente.

Já os problemas associados ao mercado externo podem ser resumidos em três pontos:

- Domínio do mercado mundial por parte da República Popular da China;

- Preços ditados pela China e muito variáveis;

\footnotetext{
${ }^{8}$ IPEF, op. cit., p.2.
} 
- Concorrência de novos produtores asiáticos.

Observando os resultados da pesquisa referentes às opiniões das empresas sobre estes problemas, constata-se um alto nível de concordância para a maioria dos problemas (Tabelas 17 e 18). Este fato vem intensificar a necessidade de organização e análise das informações presentes no setor.

Tabela 17. O grau de importância considerado para os problemas do setor, segundo os resineiros.

\begin{tabular}{lcccc}
\hline & $\begin{array}{c}\text { Muito } \\
\text { import. }\end{array}$ & $\begin{array}{c}\text { Import. } \\
\text { A falta de florestas ou áreas para resinar }\end{array}$ & $\begin{array}{c}\text { Pouco } \\
\text { import. }\end{array}$ & $\begin{array}{c}\text { S/ } \\
\text { Resposta }\end{array}$ \\
\hline Falta de mão-de-obra & $91 \%$ & $9 \%$ & & \\
Os preços dos produtos no mercado mundial & $18 \%$ & $45 \%$ & $27 \%$ & $10 \%$ \\
Produtos concorrentes (resina sintética, etc..) & $64 \%$ & $36 \%$ & & \\
Impostos & $55 \%$ & $18 \%$ & $18 \%$ & $10 \%$ \\
Transportes (fretes, gasolina, manutenções de ônibus, etc..) & $27 \%$ & $45 \%$ & $27 \%$ & \\
Legislação trabalhista complexa & $64 \%$ & $27 \%$ & $18 \%$ & \\
A concorrência & $55 \%$ & $27 \%$ & $18 \%$ & $10 \%$ \\
A falta de incentivos ou outro tipo de ajuda do governo & $27 \%$ & $45 \%$ & $9 \%$ & $10 \%$ \\
Gerenciamentos e burocracias & $18 \%$ & $18 \%$ & $55 \%$ & $10 \%$ \\
Os custos dos materiais empregados (pasta, sacões, etc..) & $18 \%$ & $45 \%$ & $36 \%$ & \\
\hline
\end{tabular}

Fonte: Pesquisa do autor, 2000.

Tabela 18. O grau de importância considerado para os problemas da atividades segundo as empresas processadoras de resina.

\begin{tabular}{|c|c|c|c|c|}
\hline & $\begin{array}{l}\text { Muito } \\
\text { import. }\end{array}$ & Import. & $\begin{array}{l}\text { Pouco } \\
\text { import. }\end{array}$ & $\begin{array}{c}\text { S/ } \\
\text { Resposta }\end{array}$ \\
\hline $\mathrm{O}$ fornecimento de matéria-prima & $100 \%$ & & & \\
\hline Preços da matéria-prima (valores, instabilidade) & $83 \%$ & & & $17 \%$ \\
\hline Preços do mercado externo & $50 \%$ & $33 \%$ & $17 \%$ & \\
\hline Os produtos concorrentes & $33 \%$ & $50 \%$ & & $17 \%$ \\
\hline Os fretes e transportes & $50 \%$ & $33 \%$ & $17 \%$ & \\
\hline Os impostos & $33 \%$ & $33 \%$ & $17 \%$ & $17 \%$ \\
\hline A legislação trabalhista & $33 \%$ & $17 \%$ & $17 \%$ & $33 \%$ \\
\hline Os produtos importados & & $17 \%$ & $50 \%$ & $33 \%$ \\
\hline Os materiais e insumos utilizados & $33 \%$ & $50 \%$ & $17 \%$ & \\
\hline A falta de incentivos ou outro tipo de ajuda do governo & $17 \%$ & $33 \%$ & $33 \%$ & $17 \%$ \\
\hline Os custos de produção de um modo geral & $33 \%$ & $17 \%$ & $33 \%$ & $17 \%$ \\
\hline
\end{tabular}

Fonte: Pesquisa do autor, 2000. 
Relativamente ao primeiro ponto, mercado interno, verifica-se que as florestas de Pinus utilizadas na exploração de resinas (plantadas na época do incentivo fiscal ao reflorestamento) começam agora a chegar ao limite de produção e ameaçam desaparecer em um prazo estimado de 10 anos. Por outro lado, com o fim dos incentivos fiscais em 29 de dezembro de 1988, pela lei 7741 , não tem havido grandes iniciativas para a reposição dessas áreas, a não ser as destinadas à auto-suficiência das empresas verticalizadas de base florestal. Este fato afeta diretamente a exploração da goma-resina e, indiretamente, por questões ecológicas e ambientais, a sociedade.

Outro problema do setor resineiro do Brasil reside no agravamento dos custos de produção (já por si elevados) que os exploradores de resina enfrentam atualmente, derivados principalmente da utilização de mão-de-obra intensiva e dos significativos impostos da legislação fiscal brasileira, como o Icms, Pis, Confins e o Inss-Prórural (ARESB $\left.{ }^{9}, 1999\right)$.

Em termos de apoio governamental, houve na década de oitenta uma iniciativa que não teve continuidade. O antigo Instituto Brasileiro de Desenvolvimento Florestal (IBDF), atual Instituto Brasileiro do Meio Ambiente (IBAMA), responsável pela política florestal brasileira, pressionado pelos valores da importação brasileira de produtos resinosos de 1980 e 1981, respectivamente de US\$ 33 milhões e US\$ 20 milhões FOB, e, considerando os seguidos aumentos anuais na produção de goma-resina brasileira, promulgou a portaria Normativa $n .^{\circ}$ 465, em 3 de dezembro de 1982, normatizando a atividade e instituindo o Plano de Resinagem de Pinus. Esta normatização da atividade não teve conseqüências e deixou de existir passados alguns anos. O que seria um excelente meio de obter controle e informação, sobre o que se passa realmente nas florestas, era sujeito a grande descontrole e não valia a pena ter seguimento.

Também as resinas e seus derivados, à semelhança da extração de látex para borracha, não estão incluídas no programa de reposição obrigatória em que se inserem outras utilizações de lenho florestal. Esta lei, apesar de não caracterizada para este setor, poderia se traduzir, quando aplicada corretamente, num meio prático e eficaz de proteção da floresta.

HOMA $^{10}$, citado por BAENA (1994), cita que a concorrência com as resinas sintéticas e com o tall oil preocupa as lideranças setoriais da goma-resina uma vez que apresenta relativo

\footnotetext{
${ }^{9}$ ARESB, op. cit. p.25.

${ }^{10}$ HOMA, M. Pesquisa pessoal. Ponta Grossa, 1994.
} 
baixo custo para as empresas de celulose brasileiras. Apesar desta citação, de acordo com a pesquisa do autor, 2000, os grandes industriais do setor das resinas naturais parecem não demonstrar grande preocupação relativamente a este problema.

As resinas sintéticas, substitutos perfeitos em algumas utilizações (borrachas, tintas, etc.), são derivadas do petróleo, e quando este se encontra a preços baixos (...ou a goma-resina em preços altos) torna-se favorável a troca e utilização do produto similar sintético. Esta rivalidade nunca ameaçou de um modo considerável este setor. No entanto, é interessante verificar que a pesquisa e desenvolvimento que se realiza na área das resinas sintéticas por grupos petrolíferos, ou para interesse destes, e outros ligados à indústria química, é muito elevada, ao contrário da $\mathrm{P} \& \mathrm{D}$ das resinas naturais.

Melhorar a capacidade de concorrência pode contribuir para amenizar os problemas enfrentados pelo setor. Neste caso, a solução pode estar associada a um esforço em pesquisa e desenvolvimento (P\&D). Como se constata, existem numerosos estudos científicos sobre o assunto mas somente algumas empresas têm realizado algum esforço de adoção com melhoramentos apenas pontuais. A exploração da resina, contra o que é aconselhado em vários estudos, continua como um complemento à exploração da madeira. Também, apesar dos muitos estudos sobre questões técnicas, são poucos os estudos de índole sócio-econômica.

Relativamente aos problemas associados ao mercado externo, a produção de resina brasileira, por representar uma percentagem ainda pouco significativa da produção mundial, não vai ter capacidade de influenciar diretamente os preços dos seus derivados. Os produtos resinosos brasileiros, considerados commodities agro-industriais, somente com um aumento substancial da sua qualidade (dificilmente atingível no curto e médio prazo) podem garantir as suas vendas e assegurar a sua posição no mercado mundial.

Relativamente aos preços dos produtos resinosos, a República Popular da China, que responde por cerca de $65 \%$ da produção total mundial, vai ser o único país capaz de determinar os preços externos. Esta, por se tratar de uma economia socialista e com necessidade de fornecer trabalho às suas populações, encontrou na resinagem o instrumento ótimo para os seus fins e, deste modo, faz tudo para assegurar o seu mercado, mesmo utilizando-se de técnicas mais rudimentares de resinagem (mão-de-obra intensiva). Os preços que pratica são muito baixos 
dificultando gravemente a participação de outros países. A elevada influência que os preços externos têm sobre os internos de outros países (Brasil, Portugal, Grécia, etc.) agravam ainda mais o problema.

Outros países ameaçam atualmente a expansão da resina brasileira e seus derivados no exterior. Países como a Indonésia, Vietnã e Coréia do Norte, com disponibilidade de florestas e mão-de-obra abundante, têm aumentado rapidamente a sua produção e a sua competitividade no mercado mundial.

\subsection{Tecnologia dos processos de fabricação}

\subsubsection{Aproveitamento Industrial do Pinus}

As florestas de Pinus têm quatro tipos de aproveitamento industrial:

- Fabricação de pasta de papel pelas empresas de celulose;

- Obtenção de madeira para serração, aglomerados, etc..;

- Obtenção de madeira como combustível (carvão);

- Obtenção de produtos resinosos (resina e óleo naturais).

No primeiro aproveitamento apenas é utilizável o tronco do pinheiro uma vez eliminada a casca. Nem os ramos nem as raízes são utilizáveis, pois prejudicam a qualidade da pasta e encarecem os custos do processo industrial. Do tratamento industrial é possível a obtenção de produtos resinosos, fato este que será referido mais adiante. No segundo aproveitamento, utilizase também somente o tronco, restringindo-se mesmo ao tronco com diâmetros elevados quando se pretende o mercado mobiliário. Para o terceiro aproveitamento utiliza-se todo o pinheiro. E finalmente o quarto aproveitamento baseia-se na coleta periódica de resina pelas técnicas descritas mais adiante.

É interessante verificar que o aproveitamento, obtenção de produtos resinosos, pode ser realizado juntamente com qualquer um dos outros tipos de aproveitamento do pinheiro. A 
resinagem quando bem realizada origina uma leve diminuição no volume e qualidade da madeira (sobretudo na primeira tora para serraria) mas esta perda é facilmente compensada através de um maior rendimento monetário e sobretudo com a antecipação das receitas.

\subsubsection{Descrição tecnológica da resinagem}

Resinagem é a atividade que consiste na extração da resina ou goma-resina de árvores vivas do gênero Pinus. No Brasil, a atividade de resinagem começou a se desenvolver na década de 1970, quando os plantios de Pinus já contavam com 20 anos de idade, e era praticada predominantemente em povoamentos florestais implantados com outros objetivos que não o de produção de resina. Com o avanço dos estudos, estima-se que num futuro próximo será possível resinar em plantios instalados exclusivamente para esta finalidade (Garrido et al, 1998).

No Brasil, devido à enorme área que este abrange, são resinadas diferentes espécies de Pinus produtoras de resina. Como se observou na Tabela 1., entre estas espécies há diferenças significativas quanto à qualidade e quantidade de resina delas extraída. Na Tabela 19., apresentase para algumas espécies encontradas no território um índice de comparação de produtividades.

Tabela 19. Produção de resina de Pinus por Kg / árvore / ano.

\begin{tabular}{lcc}
\multicolumn{1}{c}{ Espécie (variedade) } & $\mathrm{Kg} /$ Árvore / Ano & Índice de comparação (\%) \\
\hline Pinus caribaea var. caribaea & 2,85 & 137 \\
Pinus elliottii var. elliottii & 2,10 & 100 \\
Pinus caribaea var. hondurensis & 1,48 & 70 \\
Pinus oocarpa & 0,84 & 40 \\
Pinus patula & 0,59 & 28 \\
Pinus michouana & 0,39 & 18 \\
Pinus kesiya & 0,23 & 10 \\
Pinus taeda & 0,19 & 9 \\
\hline
\end{tabular}

Fonte: Garrido et al. 1998. 
Como se pode constatar a -espécie- vai ser o fator determinante para a produção de resina, mas muitos outros fatores têm um papel significativo nas produções. Note-se que parte destes fatores estão relacionados entre si. Estes fatores são, portanto, além da espécie: constituição genética, idade da planta, sanidade das árvores, dimensões da planta, fatores climáticos, (temperatura, precipitação e radiação solar), solo, sistema silvicultural (espaçamento, desbastes), sistema operacional (estimulante, dimensões dos quadros, direcionamento das estrias, técnica de resinagem).

A atividade resineira, segundo Bersaghi (1967), passou por várias fases de evolução. Antigamente fazia-se um buraco no solo, junto ao tronco da árvore, que funcionava como uma caixa de deposição. A casca e o alburno eram removidos periodicamente e a resina escorria até o buraco de onde era coletada. Atualmente, segundo o mais recente manual de resinagem publicado pelo Instituto Florestal do Estado de São Paulo (Gurgel et al, 1998), o sistema de resinagem de uma árvore compreende basicamente seis etapas:

1. Escolha da árvore no povoamento - o diâmetro à altura do peito (DAP) deve ser igual ou superior a $15 \mathrm{~cm}$. Árvores de diâmetros inferiores não são resinadas.

2. Limpeza do tronco - utilizando um instrumento "raspador do tronco" deve-se nivelar as cascas da árvore, deixando a superfície lisa.

3. Confecção do bigode - incisão em redor da árvore para a posterior fixação do recipiente coletor.

4. Colocação do recipiente coletor - geralmente são sacos de plástico fixos por arames. É importante uma boa fixação do coletor para evitar derrames ou vazamentos de resina.

5. Estriagem - incisão através de um instrumento chamado "ferro estriador" até a região do câmbio vascular e dos canais resiníferos. O corte em faixa, chamado de "estria", é de dois a três centímetros de altura e largura predeterminada para todas as árvores de acordo com o diâmetro médio do povoamento ou de acordo com o DAP da árvore. As estrias no Brasil são realizadas, regra geral, a cada 15 dias fazendo-se a nova estria em cima da anterior, e constituindo no final da safra um painel de aproximadamente quarenta centímetros de altura. A safra inicia-se em meados de setembro ou quando a temperatura começa a subir, prolongando-se até finais de maio, deixando um período de repouso para a árvore. Pode-se também resinar durante o ano todo, considerando-se neste caso o tamanho e as condições da árvore. 
6. Estimulação química - aplicação de uma pasta ácida através de uma bisnaga ou "pisseta" com a finalidade de destruir (e ir destruindo) as paredes celulósicas dos canais resiníferos, e deste modo aumentar a exsudação de resina.

No final da safra é ainda necessária a retirada da resina cristalizada (solidificada) que ficou agarrada ao painel, operação esta realizada através do instrumento "ferro raspador de resina". Esta resina é aproveitável mas, devido às impurezas que contém e oxidação a que foi sujeita, tem menor qualidade e preço inferior.

Existem diferentes técnicas de resinagem utilizadas no mundo. Estas técnicas diferem basicamente quanto ao intervalo de tempo médio entre a abertura das estrias, ao número de faces, ao tipo de estimulante utilizado, dimensões do painel etc. No entanto, sabe-se que dentro destas técnicas vão existir variações, por exemplo, devido à sazonalidade, e também, que a mesma técnica é utilizada em diferentes países sendo denominada diferentemente. Podem ser citados os seguintes métodos ou técnicas:

- Clássico (ou resinagem "à vida") - exploração de uma face de resinagem com estrias abertas em intervalos de 15 dias e utilização de estimulante ácido.

- Clássico mexicano - abertura das estrias com intervalos entre 8 e 15 dias, e utilização de pasta ácida com concentrações de 4 a 12\% de ácido sulfúrico (Porras e Prado ${ }^{11}$, citado em Baena, 1994).

- Clássico americano - abertura das estrias com intervalos de 14 dias, estrias de $2 \mathrm{~cm}$ de altura, comprimento igual ao DAP e aplicação de estimulante químico com concentração de 40\% de ácido sulfúrico (Clements e Gurgel, 1970).

- Intensivo (ou resinagem "à morte") - resinagem de duas faces simultaneamente com intervalos de abertura das estrias de 15 dias, ou resinagem de uma face com intervalos de 8 a 10 dias.

- Francês - abertura das estrias em intervalos de 8 dias e não utilização de pasta ácida.

11 PORRAS, J.M.; PRADO, A. Comparacion del metodo de resinacion de pica de corteza com estimulantes contra el metodo frances. Boletim Técnico. Instituto National de Investigacion Florestal. México, n.35, p.1-47, Feb/1981. 
- Chinês - extração de resina semelhante à extração de látex, uma face em $\mathrm{V}$, a abertura das estrias com intervalos irregulares de 3 a 4 dias consoante a produção da árvore, e inexistência de estimulante químico.

Atualmente, no Brasil, assim como em Portugal, Espanha e França, predomina o método Clássico, que é o que oferece maiores valores de produção. Note-se, entretanto, que os intervalos de coleta da resina e limpeza das estrias vão variar com as condições meteorológicas do país em questão. Assim, enquanto no Brasil o recipiente coletor chega a demorar nove dias para encher, nos outros países demora no mínimo quinze dias.

Alguns avanços tecnológicos apontam para o desenvolvimento de um novo sistema de coleta de resina, ainda em estudo, que exigirá menos mão-de-obra e fornecerá resina mais limpa. Trata-se do "sistema fechado de extração de resina" ou "resinagem por garrafas" (Hodges \& Williams, 1993).

Relativamente a estes aspectos de ordem técnica, os estudos e pesquisas são antigos e em grande número. Com o objetivo de caracterizar alguns pontos técnicos de importância para o entendimento das técnicas mais adequadas de resinagem, apresentam-se agora algumas conclusões desses estudos. Pode-se citar Clements (1961) que, estudando as produções de resina em Pinus palustris Mill. em função dos fatores climáticos, observou que a temperatura do ar, do solo e a umidade relativa do ar são responsáveis por $90 \%$ da variação na produção.

A questão da influência do clima sobre a produção de resinas em pinheiros tropicais foi discutida por Brito et al. (1978). Dentre as conclusões, destaca-se uma redução brusca na produção de resina ao fim de uma gradual diminuição na temperatura, ao contrário das espécies Pinus elliottii em que a redução acompanha a descida.

Ribas et al. (1983) verificaram para Pinus elliottii var. elliottii na floresta de Manduri variações na produção anual de $1.240 \mathrm{~g}$. a $9.260 \mathrm{~g}$. por árvore. O efeito da largura do painel para extração da resina e outros aspectos relacionados com pastas estimulantes da produção são discutidos em Fernandes et al. (1986) e Fernandes et al. (1986a). As principais considerações envolvem: 
- Para uma face de resinagem as produções crescem na proporção do aumento da largura do painel;

- Explorando duas faces simultaneamente as produções não diferem estatisticamente por efeito da largura dos painéis;

- Ganhos de produção em duas faces; em relação a uma face;

- Testando quatro concentrações diferentes para pasta estimulante à base de ácido sulfúrico, verificaram que estas influenciam fortemente a produção de resina.

Ribas, Assini e Gurgel Garrido (1986) estudaram estimulantes com diferentes concentrações de ácido sulfúrico e chegaram às mesmas conclusões.

O potencial de aumento da produtividade com base na utilização de material genético melhorado é comentada por Fonseca e Kageyama (1978). Segundo estes autores a variação genética ou hereditária é a que realmente importa para os trabalhos de melhoramento, obtendo-se ganhos em florestas melhoradas da ordem de 17\% a 152\% consoante a técnica utilizada. Estes autores listam também as cinco principais espécies produtoras de resina no mundo: Pinus elliottii var. elliottii, Pinus caribaea de variedades caribaea, hondurensis e bahamensis, Pinus pinaster e Pinus sylvestris.

Segundo Gurgel Filho e Faria (1978), pode-se utilizar os testes de progênie e avaliações precoces da produção de resina para maximizar os ganhos genéticos por unidade de tempo. Oliveira (1987), realizando estudos na floresta Nacional de Capão Bonito e na estação experimental de Itapetininga, mostra que existem ganhos em progênies diferentes de Pinus eliottii, revelando o potencial da população que pode ser explorada em termos de seleção e melhoramento com a espécie.

Muramoto e Pinheiro (1987) ${ }^{12}$ referem-se aos fatores que mais influenciam a produção de resina, dentre os quais a temperatura, a precipitação e a umidade, e para além destes fatores climáticos citam também os fatores genéticos e características de manejo como o diâmetro das árvores no momento do corte, o comprimento e largura da estria, o intervalo entre aberturas de estrias, e o estimulante. 


\subsubsection{Descrição tecnológica do processamento da resina}

A indústria de resinas compreende os processos de transformação que ocorrem já nas unidades fabris. A resina-bruta sai da floresta geralmente em tambores metálicos de 200 litros com muitas impurezas (folhas, insetos, ramos, cascas, etc.), e, via lavagem e destilação, dá origem ao breu e terebintina, produtos que têm as suas propriedades e características testadas no laboratório. Verifica-se a transformação de um produto de relativo baixo valor em produtos de valor agregado mais significativo (vide Figura 19).

Nesta fase, são utilizados processos físicos simples de separação e purificação dos produtos, que, devido às quantidades envolvidas, exigem equipamento adequado.

O sistema denominado de "destilação contínua da resina", via processo "Ollustee"13 desenrola-se segundo os seguintes pontos:

1. A resina natural é depositada num tanque reservatório, que por sua vez, alimenta um tanque pré-aquecedor, sendo aquecida com vapor direto e indireto. É adicionado ácido oxálico para a precipitação do ferro contido na resina e terra diatomácea que vai agir como auxiliar de filtração. Atingida uma determinada temperatura, a resina é transferida para o outro tanque.

2. Neste tanque chamado de tanque de fusão é acrescentada terebintina (30 a $35 \%$ do total) para diluição da resina. A solução é aquecida e filtrada a quente com auxilio da pressão de vapor.

3. O filtrado é recolhido num tanque de lavagem onde é deixado a decantar por 4 a 8 horas a uma temperatura de aproximadamente $80^{\circ} \mathrm{C}$.

4. Uma vez acabado o tempo de decantação, a solução lavada e filtrada é bombeada através de um pré-aquecedor tubular e introduzida no topo da coluna de filtração.

5. Na coluna de destilação que contém anéis de Raschig, a solução vai descer, em contra corrente com os vapores ascendentes. Desta forma a terebintina é separada do breu, saindo pelo topo da coluna e passando por um separador, para que sejam retiradas partículas de breu que tenham sido arrastadas.

${ }^{12}$ MURAMOTO, M.C.; PINHEIRO, C.N.F. Palestra apresentada sobre resinagem em Pinus, Grupo Ultra, São Paulo, 1987.

13 "Ollustee" é a cidade onde foi desenvolvido este processo na Florida, EUA, na década de 1950. 
6. Os vapores efluentes da coluna passam por um condensador refrigerado a água e o condensado é recolhido num separador onde se efetua a separação da água e da terebintina.

7. A terebintina passa por um desidratador contendo sal de rocha.

8. O breu escoa pela base da coluna.

Outros processos de destilação da resina, como o processo com "vácuo" e o processo "batch" de gravidade ou batelada, apresentam poucas diferenças relativamente ao acima descrito.

Atualmente, o processo de destilação por batelada, é o mais utilizado possuindo adaptações e tecnologia aperfeiçoadas ao longo de anos. Um exemplo são os malaxadores, instrumentos atualmente fundamentais que substituem os pontos um e dois. São estas adaptações tecnológicas e diferentes métodos que vão distinguir as diferentes capacidades produtivas e qualidade dos produtos que, por sua vez, podem fazer a diferença no negócio.

Outro ponto a destacar é o armazenamento dos diferentes produtos. Primeiramente, a resina, antes de entrar no processo, é deixada dentro dos tambores, empilhada em grandes pátios. Mas, devido à possibilidade de oxidação e até rompimento dos tambores, é aí mantida somente por intervalo pequeno. O breu pode ser armazenado sob a forma líquida ou sólida. A líquida é feita em grandes reservatórios permanentemente aquecidos e de preferência fora do contato com o ar. Quando sólido, assume as mais variadas formas segundo os requerimentos dos clientes. Assim, para exportação segue geralmente dentro de tambores de aço galvanizado de $250 \mathrm{Kg}$ bem fechados, mas podendo também seguir nas diferentes formas de embalagens utilizadas, ou seja, em tambores de papelão de $250 \mathrm{Kg}$, caixas de papelão de $25 \mathrm{Kg}$, ou ainda, triturado em sacas de $25 \mathrm{Kg}$ cada.

A terebintina, por ser volátil e por sofrer modificações progressivas ao longo do tempo (aumento da viscosidade, diminuição da volatilidade e aumento da turvidez), é armazenada em grandes tanques de material apropriado resistente a solvente. 


\section{ESTRUTURA DE CUSTOS DE PRODUÇÃO}

Analisando as operações de exploração de resina e primeira transformação, verifica-se que os custos da primeira operação -resinagem- vão influenciar diretamente a competitividade econômico-financeira da segunda operação -processamento- e de muitas outras a jusante. Esta influência vai demonstrar-se sobretudo nos preços dos produtos resinosos.

Relativamente à primeira operação, a resinagem, em alguns países desenvolvidos, os custos associados à mão-de-obra presumem-se o fator mais limitante ao crescimento do setor. Cita-se o exemplo francês nos anos 60, o norte-americano na década de 50 e, em Portugal, Espanha e Grécia, desde 1993.

Deduz-se, por estes motivos, que a razão da China ser o maior produtor de produtos resinosos esteja diretamente ligada ao fato de ser um país com mão-de-obra em abundância e, por conseqüência, barata. Isto vai implicar em custos de produção muito baixos para a China, fazendo com que o preço do seu produto também seja baixo. Também é fato de conhecimento geral que a China incentiva fortemente a exploração da resina o que não acontece em nenhum país do ocidente, onde se insere o Brasil.

De um modo geral, deve-se considerar que a produção é influenciada pela produtividade da força de trabalho e pela eficiência do gerenciamento, características estas que também variam com o local. Os custos são específicos para cada região ou local, podendo haver diferenças significativas consoante as características do local.

O estudo realizado em 1978 pelas INDÚSTRIAS QUÍMICAS CARBOMAFRA S.A. retrata aspectos dos custos de resinagem, considerado de maior importância: os custos com o 
material, os custos da mão-de-obra, e os custos derivados do arrendamento de florestas para resinagem. Referem-se igualmente os custos derivados da mão-de-obra, ou seja, os custos por estria, por coleta, por fechamento do tambor, o valor do material colocado por árvore, o valor total pago por dia, o salário médio mensal, etc. Estes valores, apesar de interessantes, apresentam uma defasagem temporal elevada.

O Instituto Florestal de São Paulo apresenta, através do Florestar Estatístico, os valores de insumos (material e serviços) utilizados na resinagem, para vários anos, observando dados da Fundação Florestal. Incluem-se, entre outros, valores de pasta estimulante, arame, instrumento estriador, sacos de plástico, tambores, e serviço de coleta estrias, e transportes.

Figueiredo Filho (1991) considera que os custos para produzir a resina podem diferir significativamente de acordo com as técnicas, equipamentos e materiais empregados e, principalmente, pela disponibilidade de mão-de-obra regional. Para a resinagem, consideram-se os custos anuais por unidade, ou seja, custo por árvore por ano e, por conseguinte, estabelecemse também as produções e receitas por árvore por ano. Este critério é importante e tem a sua validade respaldada na linguagem normalmente adotada pelos técnicos das empresas que operam a atividade de resinagem, os quais fazem as suas análises sempre ao nível de árvore.

Figueiredo Filho (1991) descreve ainda em seu trabalho os resultados de uma análise de viabilidade de florestas de Pinus elliottii Eng. var. elliottii com idades de média 23 anos, resinadas pelo método americano, e localizadas no município de Telêmaco Borba, Paraná. Encontrou os seguintes resultados: (I) rentabilidade positiva a partir da produção média de resina por árvore por ano superior a 2,5 Kg; (II) reduções no incremento do volume de $15 \%$, na altura total de $12 \%$ e de 6 a 16,5\% nos diâmetros ao longo do tronco; (III) redução do volume total e comercial de 26 e $25,5 \mathrm{~m}^{3}$ por hectare, respectivamente; (IV) não houve alteração na forma das árvores; e (V) ganhos nas receitas líquidas após 8 anos de resinagem da ordem dos US\$ 504 /ha em relação à floresta não resinada, ou seja, 17,8\% superior à alternativa de não resinar, considerando preços, custos, taxa de capitalização e densidade por hectare, já considerando a redução volumétrica. 
Koppen \& Hone (1995) através do Tabela 20., apresentam uma previsão detalhada dos custos de pré-produção, iniciação, investimentos iniciais, derivados da mão-de-obra e custos anuais, para uma empresa que realize uma operação de resinagem em países africanos a preços de 1995. Não é especificado qual o país, qual o número de funcionários na resinagem, e qual o tipo de resina explorada.

Tabela 20. Previsão dos custos iniciais e anuais de produção da operação de resinagem para um país africano, a preços de 1995 (produção de 1000 toneladas de resina extraídas de 400.000 árvores).

Parciais Totais

(US\$) (US\$)

\section{CUSTO DE PRÉ-PRODUÇÃO}

Recrutamento e treinamento de mão-de-obra; despesas de gerenciamento e administração; material para treinamento.

CUSTOS DE INVESTIMENTOS FIXOS

Preparação do local; dos pontos de armazenamento e carregamento. $\quad 5000$

Edifícios para os trabalhadores e para escritório.

65000

Material necessário para a produção: arames, sacos de plásticos, ferramentas de resinagem, pasta estimulante, botas, luvas, etc.

80000

Outros Materiais: veículos, material de escritório, etc.

70000

Contingências $(10 \%)$

22000

242000

\section{CUSTOS INICIAIS DE MÃO-DE-OBRA}

Custos dos primeiros três meses de trabalho: salários, despesas de instalação,

Despesas para exploração, licenças e seguros dos veículos, etc.

\section{TOTAL DOS CUSTOS PRÉ-PRODUÇÃO}

\section{CUSTOS ANUAIS DE PRODUÇÃO}

Custo de mão-de-obra: diárias e salários

Licença de exploração das árvores

30000

Pagamento de resinagem por terceiros (considerando a resinagem de 200 árvores, de duas faces, por dia de trabalho).

80000

Material para produção:

Pregos, arames e plásticos. $\quad 9000$

Pasta estimulante (ácida) $\quad 15000$

Transporte: gasolina, licenças e seguros dos veículos $\quad 35000$

Manutenção e substituição de equipamentos 10000

Materiais diversos

15000

Contingências (10\% de todos os itens exceto os três primeiros)

$8400 \quad 222400$

Despesas anuais em investimentos fixos e de exploração (20\% variável)

73100 
As empresas de resinagem de J. Lopes e O. Lima, produtores rurais, contribuíram para a pesquisa do autor, disponibilizando a apuração de seus custos de um modo bastante elucidativo para este trabalho.

Consideraram-se duas situações observadas nas Tabelas 21 e 22. Primeiro, 1 milhão de faces/árvores a resinar de resina Elliottii (Pinus elliiottii), considerando 24 estrias no ano e com uma produção de $2,5 \mathrm{Kg}$ por face por ano; e segundo, 1 milhão de faces/árvores a resinar de resina Tropical (Pinus caribaea), considerando 25 estrias no ano e com uma produção de $3,2 \mathrm{Kg}$ por face por ano. Estes valores de custo são relativos à produção total retirada, não considerando a parcela da produção destinada ao arrendamento que se situa entre 20 e $30 \%$.

Detalhando alguns aspectos dos custos apresentados nas Tabelas 21 e 22, dentro dos custos das instalações, os custos com alojamentos do pessoal e encarregados são referentes à compra $^{14}$ de terrenos e construção nos mesmos de casas (acampamentos) para alojamento de funcionários $^{15}$, e são calculados rateando o total gasto nas instalações pelos anos a resinar. Os encargos com os alojamentos referem-se às manutenções, energia elétrica, água, parte do telefone, etc., com os alojamentos dos funcionários e encarregados. Também se inserem dentro destes custos os gastos com a manutenção do escritório, contabilidade, etc. Os custos com materiais são referentes, principalmente, aos gastos com insumos/materiais utilizados na operação de resinagem. Os custos com a mão-de-obra são referentes ao pagamento dos funcionários por realizarem as diversas operações da resinagem, ou seja, o pagamento da estrias, da raspagem, da colocação dos saquinhos, coleta, etc. Os custos com transporte referem-se sobretudo à aquisição de veículos (camionetas, ônibus, etc.) e aos gastos com o transporte de funcionários que residem longe das florestas (de modo alternativo/complementar aos alojamentos na floresta), e transporte dos funcionários residentes nas florestas até às povoações para compras de supermercado, serviços de banco, lazer, etc., providenciados pelo empresário resineiro. Finalmente, os custos com administração são relativos aos ordenados dos gerentes, supervisores, monitores, motoristas, etc.

\footnotetext{
${ }^{14}$ Por vezes, em se tratando de grande número de pessoas, as prefeituras cedem os terrenos para a construção.

${ }^{15}$ Os alojamentos/acampamentos costumam servir para alojar funcionários, muitas vezes já treinados, provenientes de lugares distantes, ou quando a floresta a resinar se situa longe de povoações.
} 
Tabela 21. Custos calculados para uma operação de resinagem em floresta de Pinus elliiottii em R\$ (2000) e safra 2000/01 (produção anual de 2.500 toneladas de resina extraídas de 1.000.000 de arvores).

\begin{tabular}{ccc}
\hline & Parciais & Totais \\
$(\mathrm{R} \$)$ & $(\mathrm{R} \$)$
\end{tabular}

CUSTO DAS INSTALAÇÕES

$\begin{array}{ll}\text { Alojamentos do pessoal e encarregados } & 20000\end{array}$

Encargos com os alojamentos (energia, telefone, ..) 14600

$\begin{array}{ll}\text { Assistência informática e contabilidade } & 5760\end{array}$

$\begin{array}{ll}\text { Escritório com seus encargos } & 3840\end{array}$

$\begin{array}{lr}\text { Licenças e cadastros } & 1780\end{array}$

$\begin{array}{lr}\text { Outros } & 10000\end{array}$

56000

CUSTOS MATERIAIS

Sacos $\quad 114000$

$\begin{array}{ll}\text { Arames } & 21900\end{array}$

$\begin{array}{ll}\text { Pasta estimulante } & 20160\end{array}$

Instrumentos de trabalho $\quad 2000$

$\begin{array}{lr}\text { Outros } & 2000\end{array}$

160000

CUSTOS MÃO-DE-OBRA

Estrias

264960

Raspa da casca, preparação da embalagem, 100000

$\begin{array}{lr}\text { Coleta e carga de tambores } & 100000\end{array}$

$\begin{array}{ll}\text { Diárias } & 12700\end{array}$

Cestas básicas $\quad 36000$

$\begin{array}{ll}\text { Outros } & 21000\end{array}$

535000

CUSTOS TRANSPORTES

Ônibus com manutenção e gasolina $\quad 24000$

Caminhões, tratores (manutenção e gasolina) 30000

Veículos encarregado $\quad 9000$

$\begin{array}{ll}\text { Outros } & 2000\end{array}$

65000

CUSTOS ADMINISTRAÇÃO

$\begin{array}{ll}\text { Ordenados supervisor } & 16000\end{array}$

$\begin{array}{ll}\text { Ordenado encarregados de campo } & 13000\end{array}$

Monitores, tratoristas e motoristas $\quad 50000$

$\begin{array}{lr}\text { Outros } & 9000\end{array}$

101000

TOTAL DOS CUSTOS

917000

Fonte: Pesquisa do autor, 2000. 
Tabela 22. Custos calculados para uma operação de resinagem em floresta de Pinus caribaea em $\mathrm{R} \$(2000)$ e safra 2000/01 (produção anual de 3.200 toneladas de resina extraídas de 1.000.000 de árvores).

\begin{tabular}{ccc}
\hline & $\begin{array}{c}\text { Parciais } \\
(\mathrm{R} \$)\end{array}$ & $\begin{array}{c}\text { Totais } \\
(\mathrm{R} \$)\end{array}$ \\
\hline
\end{tabular}

CUSTO DAS INSTALAÇÕES

Alojamentos do pessoal e encarregados $\quad 24000$

$\begin{array}{ll}\text { Encargos com os alojamentos (energia, telefone, ..) } & 11000\end{array}$

$\begin{array}{ll}\text { Assistência informática e contabilidade } & 10000\end{array}$

$\begin{array}{ll}\text { Escritório com seus encargos } & 25000\end{array}$

$\begin{array}{lr}\text { Licenças e cadastros } & 1780\end{array}$

$\begin{array}{ll}\text { Outros } & 4000\end{array}$

CUSTOS COM MATERIAIS

$\begin{array}{ll}\text { Sacos } & 160000\end{array}$

Arames $\quad 30000$

$\begin{array}{ll}\text { Pasta estimulante } & 21000\end{array}$

Instrumentos de trabalho $\quad 20000$

$\begin{array}{ll}\text { Outros } & 9000\end{array}$

240000

CUSTOS MÃO-DE-OBRA

Estrias

260000

Raspa da casca, preparação da embalagem, $\quad 150000$

$\begin{array}{lr}\text { Coleta e carga de tambores } & 140000\end{array}$

$\begin{array}{ll}\text { Diárias } & 12700\end{array}$

Cestas básicas $\quad 46800$

$\begin{array}{ll}\text { Outros } & 27000\end{array}$

636000

CUSTOS TRANSPORTES

Ônibus com manutenção e gasolina $\quad 50000$

Caminhões, tratores (manutenção e gasolina) $\quad 15000$

$\begin{array}{lr}\text { Veículos encarregado } & 15000\end{array}$

$\begin{array}{lr}\text { Outros } & 2000\end{array}$

82000

CUSTOS ADMINISTRAÇÃO

Ordenados Gerente Administrativo e de campo 30000

$\begin{array}{ll}\text { Ordenado encarregados de campo } & 40000\end{array}$

$\begin{array}{ll}\text { Enfermeira } & 7000\end{array}$

$\begin{array}{ll}\text { Monitores, tratoristas e motoristas } & 1000\end{array}$

$\begin{array}{ll}\text { Outros } & 8000\end{array}$

TOTAL DOS CUSTOS

Fonte: Pesquisa do autor, 2000.

É interessante mencionar que os funcionários que efetuam as operações de resinagem são, na sua maioria, pagos por produção, ou seja, para cada uma das operações efetuadas eles vão receber uma quantia. Deste modo, o funcionário com maior produtividade será recompensado e a operação beneficiada. De acordo com empresas do setor, os funcionários na 
floresta com boa produtividade de trabalho podem chegar a receber mais de 800,00 reais mensais.

Observando a Tabela 23, podem-se inferir vários resultados para as tabelas de custos adquiridas para a operação de resinagem, atendendo as diferentes situações enunciadas. Constata-se que a operação de resinagem é mão-de-obra intensiva no Brasil, uma vez que os custos derivados da mão-de-obra representam parcela significativa dos custos de produção e influenciam fortemente a lucratividade da resinagem. Uma menor parcela dos custos, ainda derivados da mão-de-obra, é a necessária para o supervisionamento da coleta, armazenamento e transportes de resina dentro da floresta e para as unidades fabris de processamento da resina.

Tabela 23. Comparação de percentuais de custos estimados para operações de resinagem na África e no Brasil para resina "elliottii" e "tropical".

\begin{tabular}{lccc}
\hline & África* & $\begin{array}{c}\text { Brasil } \\
\text { Pinus elliiottii }\end{array}$ & $\begin{array}{c}\text { Brasil } \\
\text { Pinus caribaea }\end{array}$ \\
\hline PRODUÇÕES & $2,5 \mathrm{Kg} /$ árvore & $2,5 \mathrm{Kg} /$ árvore & $3,2 \mathrm{Kg} /$ árvore \\
CUSTOS ANUAIS & 400.000 árvores & 1.000 .000 árvores & 1.000 .000 árvores \\
Custos de instalação & & & \\
Custos com materiais & $34 \%$ & $6 \%$ & $7 \%$ \\
Custos mão-de-obra & $23 \%$ & $17 \%$ & $21 \%$ \\
Custos com transportes & $25 \%$ & $58 \%$ & $57 \%$ \\
Custos administrativos & $11 \%$ & $7 \%$ & $7 \%$ \\
\hline
\end{tabular}

Fonte: Pesquisa do autor, 2000.

* adaptado a partir das tabelas de Koppen \& Hone, 1995.

Os custos derivados do arrendamento das florestas para realização da resinagem estão embutidos nos valores de custo apresentados na Tabela 23, e representam comparativamente ao caso da resinagem em floresta própria um acréscimo estimado de 26,35 e $25 \%$, respetivamente, para as três opções apresentadas.

Em relação às cargas tributárias, a empresa Comercial Majuara contribuiu para o presente trabalho, fornecendo dados bastante elucidativos do assunto para a operação de resinagem supondo as situações de produtor rural e de empresas pessoa jurídica (Tabela 24). 
Tabela 24. Cargas tributárias sobre a operação de resinagem

\begin{tabular}{lcc}
\hline & Pessoa Física & Pessoa Jurídica \\
\hline SOBRE A FOLHA DE PAGAMENTOS & & \\
FGTS & $8 \%$ & $8 \%$ \\
FGTS sobre férias & $0,89 \%$ & $0,89 \%$ \\
FGTS sobre salário & $0,67 \%$ & $0,67 \%$ \\
Contribuição federativa & $1 \%$ & $1 \%$ \\
INSS - folha & $2,7 \%$ & $28,8 \%$ \\
Férias + $13^{\circ}$ & $11,11 \%$ & $11,11 \%$ \\
$13^{\circ}$ salário & $8,33 \%$ & $8,33 \%$ \\
SOBRE A NOTA FISCAL $^{\circ} \%$ & \\
ICMS & & \\
& & $18 \%$ (dentro do estado) \\
PIS & $18 \%$ (dentro do estado) & $18 \%$ (Sul e Sudeste) \\
COFINS & $8 \%$ (Norte e Nordeste) & $8 \%$ (Norte e Nordeste) \\
PRO-RURAL & -- & $0,65 \%$ \\
IR (sobre o LUCRO) & -- & $3 \%$ \\
\hline
\end{tabular}

Fonte: Pesquisas do autor, 2000.

Relativamente aos custos envolvidos com a segunda operação, processamento da resina, estes não diferem dos custos de uma unidade fabril da indústria química que lide com commodities agro-industriais, que vão ser bastante elevados no arranque e início da produção devendo passar a valores cada vez menores num horizonte de tempo mais longo.

Generalizando sobre a competitividade da indústria química brasileira em geral, a ABIQUIM (1999) constata que esta resulta seriamente prejudicada por três fatores: custo dos insumos básicos, custo dos bens de capital, e a carga tributária. Tradicionalmente, para o tipo específico de indústria processadora de goma-resina, impera o custo da matéria-prima e de outros insumos de produção. Este custo explica a estreita ligação existente entre as várias etapas presentes na cadeia.

\footnotetext{
${ }^{16}$ A incidência do ICMS não é igual para todos os estados brasileiros. Aqui está sendo usado o exemplo do Estado de Minas Gerais. Nos estados de São Paulo e Paraná, por decreto estadual, a comercialização da goma-resina não obriga a retenção do imposto de comercialização (ICMS), sendo portanto beneficiados os seus produtores.
} 
Koppen \& Hone (1995) mais uma vez apresentam os custos iniciais e anuais para a operação de processamento da resina num país africano (Tabela 25), seguindo o esquema apresentado anteriormente para a operação de resinagem.

Tabela 25. Previsão dos custos iniciais e anuais da operação de processamento da resina para um país africano, a preços de 1995.

\begin{tabular}{|c|c|c|}
\hline & $\begin{array}{c}\text { Parciais } \\
\text { (US\$) }\end{array}$ & $\begin{array}{l}\text { Totais } \\
\text { (US\$) }\end{array}$ \\
\hline \multicolumn{3}{|l|}{ CUSTO DE PRÉ-PRODUÇÃO } \\
\hline Pagamento pelo "Know how" técnico & 20000 & \\
\hline Recrutamento e treinamento da mão-de-obra, material para testes & 25000 & \\
\hline Contingências $(10 \%)$ & 4500 & 49500 \\
\hline \multicolumn{3}{|l|}{ CUSTOS DE INVESTIMENTOS FIXOS } \\
\hline Preparação do local e infra-estruturas. & 10000 & \\
\hline Fábrica & 60000 & \\
\hline Outros edifícios como vestiários, refeitórios lavabos, etc. & 80000 & \\
\hline Contingências $(10 \%)$ & 15000 & \\
\hline Caldeira (importada) & 74000 & \\
\hline Outros equipamentos para a produção & 240000 & \\
\hline Outros Materiais: veículos, material de escritório, etc. & 60000 & \\
\hline Contingências $(5 \%)$ & 18700 & 557700 \\
\hline TOTAL DOS CUSTOS DE PRÉ-PRODUÇÃO & & 607200 \\
\hline \multicolumn{3}{|l|}{ CUSTOS ANUAIS DE PRODUÇÃO } \\
\hline Custo de mão-de-obra: diárias e salários (mão-de-obra permanente) & 84000 & \\
\hline Insumos iniciais da produção: 1000 toneladas de resina a US\$ 295 por tonelada. & 295000 & \\
\hline Material para produção: filtros, água de diatomácea, ácido oxálico, etc. & 20000 & \\
\hline Transporte: pagamento a Terceiros, gasolina, licenças e seguros dos veículos & 36000 & \\
\hline Manutenção e substituição de equipamentos & 10000 & \\
\hline Material de embalagens & 7000 & \\
\hline Materiais diversos: escritório, eletricidade, telefone, fax, etc. & 30000 & \\
\hline Contingências (incluindo insumos para suprir dois meses de produção) & 65000 & 547000 \\
\hline Despesas anuais em investimentos fixos $(20 \%)$ & 121400 & 121400 \\
\hline TOTAL DOS CUSTOS & & 668400 \\
\hline
\end{tabular}

Fonte: Koppen \& Hone (1995).

Por meio de uma pesquisa direta do autor junto às empresas produtoras de resina e empresas processadoras de resina, procurou-se obter respostas relativas aos custos presentes nas operações de resinagem e processamento de resina. 
Assim, segundo a amostra adquirida junto aos produtores de resina, constata-se um nível de importância elevado atribuído a quatro itens de custo: custos de instalação; comercialização; mão-de-obra; e derivados de questões ambientais. Relativamente aos custos de materiais diretos e derivados do arrendamento das florestas, o nível de importância atribuído foi de nível médio e sobre os custos fixos de funcionamento, as respostas não se apresentaram coincidentes, não se podendo inferir sobre elas (Tabela 26).

Tabela 26. Grau de importância atribuído aos custos presentes na operação de resinagem 2000.

\begin{tabular}{|c|c|c|c|c|}
\hline Tipos de custos & Elevado* & Médio* & Baixo* & $\begin{array}{c}\mathrm{S} / \\
\text { resposta }\end{array}$ \\
\hline $\begin{array}{l}\text { Custos de instalação (Veículos, acampamentos, licenças, } \\
\text { treinamentos, etc.) }\end{array}$ & $64 \%$ & $27 \%$ & $9 \%$ & \\
\hline $\begin{array}{l}\text { Custos dos materiais diretos (Limpezas na florestas, } \\
\text { uniformes, pasta, sacões, etc.) }\end{array}$ & $18 \%$ & $73 \%$ & $9 \%$ & \\
\hline $\begin{array}{l}\text { Custos de comercialização (Fretes, impostos de } \\
\text { comercialização, financeiros, etc.) }\end{array}$ & $64 \%$ & $36 \%$ & & \\
\hline $\begin{array}{l}\text { Custos de mão de obra direta (Pagamentos, gerenciamentos } \\
\text { diretos, encargos sociais, etc.) }\end{array}$ & $91 \%$ & $9 \%$ & & \\
\hline $\begin{array}{l}\text { Custos fixos de funcionamento (Transporte de funcionários, } \\
\text { manutenções, impostos, etc.) }\end{array}$ & $45 \%$ & $45 \%$ & $9 \%$ & \\
\hline Custos com o arrendamento das florestas & $45 \%$ & $55 \%$ & & \\
\hline Custos derivados de questões ambientais & $55 \%$ & $18 \%$ & $27 \%$ & \\
\hline
\end{tabular}

Fonte: Pesquisa do autor, 2000.

* Percentagem de respostas sobre o total da amostra.

Especificamente sobre os custos de instalação, a maioria das empresas questionadas concordou com a atribuição de grau nível médio para treinamento de funcionários na florestas e para os custos de máquinas e veículos. Para os restantes custos (equipamentos e utensílios, de formação e montagem de acampamentos e escritórios, com impostos de instalação, licenças e outros), as empresas não concordaram com o nível de importância a atribuir.

Sobre os custos com materiais diretos, as empresas questionadas parecem concordar com a elevada importância das manutenções, limpezas e roçadas das florestas, e dos custos com as embalagens, estimulante e outros. 
Sobre os custos de comercialização, destaca-se a elevada importância atribuída aos impostos de comercialização e a média importância dos mesmos com fretes da goma-resina (previa-se um maior nível de importância).

Relativamente à mão-de-obra direta, 100\% das empresas questionadas consideraram de elevada importância os custos com a folha de pagamento. Também se constatou elevada importância relativamente aos impostos e encargos sociais e média importância aos custos derivados de legislação trabalhista e de administração do pessoal.

Finalmente, sobre os custos de funcionamento, as empresas apenas concordaram em que o transporte dos funcionários e as cargas trabalhistas eram de elevada importância e que os custos com combustíveis e lubrificantes eram de média importância.

Relativamente aos custos de processamento de resina, constatou-se uma certa indefinição nas respostas das empresas questionadas. Como se pode observar na Tabela 27., é difícil perceber um nível de importância para cada um dos itens de custos especificados.

Tabela 27. Grau de importância atribuído aos custos presentes na operação de processamento de resina, 2000.

\begin{tabular}{|c|c|c|c|c|}
\hline Tipos de custos & Elevado* & Médio* & Baixo* & $\begin{array}{c}\text { S/ } \\
\text { resposta }\end{array}$ \\
\hline $\begin{array}{l}\text { Custos de instalação (know how, montagem, infra- } \\
\text { estruturas, equipamentos, treinamentos, etc.) }\end{array}$ & $33 \%$ & $67 \%$ & & \\
\hline $\begin{array}{c}\text { Custos dos materiais diretos (Matéria prima processadas, } \\
\text { insumos, uniformes e EPI's, embalagem, etc.) }\end{array}$ & $50 \%$ & $50 \%$ & & \\
\hline $\begin{array}{l}\text { Custos de comercialização (Representações, fretes, } \\
\text { impostos, etc.) }\end{array}$ & $50 \%$ & $50 \%$ & & \\
\hline $\begin{array}{l}\text { Custos de mão de obra direta (Pagamentos, encargos } \\
\text { sociais, obrigações trabalhistas, etc.) }\end{array}$ & $50 \%$ & $50 \%$ & & \\
\hline $\begin{array}{l}\text { Custos fixos de funcionamento (Transporte de } \\
\text { funcionários, manutenções, impostos, licenças, etc.) }\end{array}$ & $33 \%$ & $50 \%$ & & $17 \%$ \\
\hline Custos administrativos ou gerenciais & $17 \%$ & $33 \%$ & $33 \%$ & $17 \%$ \\
\hline $\begin{array}{l}\text { Custos derivados de programas de qualidade (Auditorias, } \\
\text { consultorias, etc.) }\end{array}$ & $17 \%$ & $33 \%$ & $33 \%$ & $17 \%$ \\
\hline $\begin{array}{l}\text { Custos derivados de questões ambientais (Efluentes, } \\
\text { resíduos, etc.) }\end{array}$ & $33 \%$ & $50 \%$ & & $17 \%$ \\
\hline
\end{tabular}

Fonte: Pesquisa do autor, 2000.

* Percentagem de respostas sobre o total da amostra. 
De modo geral, as empresas do setor, quer sejam referentes a operação de resinagem quer sejam a operação de processamento de resina, demonstraram no conjunto uma não concordância quanto aos itens de custos mais importantes para as suas operações. Este fato origina alguma dúvida e indefinição sobre este aspecto dos custos.

Mas, concluindo sobre a estrutura e importância atribuída aos custos presentes nestas operações, depreende-se sobre a primeira operação a existência de três itens de custo mais importantes: os custos relacionados com a mão-de-obra; os custos de instalação e os custos de comercialização com particular incidência nas cargas tributárias. Sobre os itens de custo restantes, pela pesquisa efetuada, não se percebeu serem decisivos para a operação em geral.

É de relevar a total concordância (100\% das respostas) das empresas questionadas sobre o item mão-de-obra. Como se previa, é fator extremamente importante para a operação de resinagem. A boa atuação da força de trabalho nas florestas vai ser de importância fundamental para a minimização deste item de custo, uma vez que os outros fatores relacionados com a produtividade da árvore são mais difíceis de melhorar.

Sobre a operação de processamento de resina, a pesquisa efetuada não revelou itens de custo decisivos (pode-se dizer que estão bem distribuídos). Apenas se constatar uma estreita dependência, já suspeitada, com a operação anterior na cadeia por motivos de abastecimento e apuramento de preços da sua matéria-prima (goma-resina).

De modo geral, não se percebeu pelos itens de custo nenhuma situação crítica para os dois tipos de operação questionados. Talvez somente o fator mão-de-obra na operação de resinagem (que repassaria para os derivados da resina pelos preços da matéria-prima) apresentase alguma suspeita mas nada de alarmante quando se compara com as mesmas operações em outros países como Portugal, Espanha e Grécia.

Apesar da situação brasileira não estar totalmente tranqüila pelos problemas bastante graves que enfrenta, como o corte das florestas, concorrência com a China, etc. (capítulo 4), os problemas da atualidade, derivados dos custos de produção, ainda permitem uma estreita margem de crescimento mesmo com tendência decrescente no tempo. Confirma-se deste modo a segunda hipótese considerada. 


\section{ANÁLISE DA CADEIA PRODUTIVA}

\subsection{Considerações sobre a cadeia}

Tradicionalmente, a análise das alternativas de terceirização e integração limita-se à comparação entre os custos de produção associados a cada uma das formas organizacionais. A ECT vem trazer um instrumental novo, mais realista, baseado nas relações contratuais firmadas pelas empresas (correspondendo aos elos de união entre cada estágio da cadeia produtiva).

As características da transação (especificidade dos ativos, freqüência e incerteza), associadas aos pressupostos comportamentais de racionalidade limitada e oportunismo, são os fatores componentes do modelo da ECT para a escolha da forma organizacional mais eficiente para governar uma transação.

Este tipo de análise nunca se realizou para o setor dos produtos resinosos. As poucas referências de caráter econômico sobre o setor são descritivas e/ou prendem-se sobretudo a análises de viabilidade de alternativas dentro do setor, principalmente da operação de resinagem.

Costa et al (1998), usando outro tipo de referencial teórico, analisaram três opções para obtenção de matéria-prima pela indústria resineira: compra de terra para suprimento próprio, arrendamento da terra e, finalmente, a compra de resina no mercado. Utilizaram a técnica de dominância estocástica, para a seleção das alternativas que seriam escolhidas por empresários avessos ao risco. 
A primeira opção exige um alto investimento mas possibilita à empresa explorar a madeira no final do ciclo. Na segunda opção, não se compra a terra, portanto, não há grande investimento inicial e a madeira não é explorada pela empresa. Finalmente, a terceira opção possibilita à empresa ter pouco capital empatado e baixos custos de produção, mas torna-a dependente do mercado e uma vez que os preços da resina são variáveis, esta pode não ser a melhor escolha.

Considerando as opções analisadas, chegaram às seguintes conclusões:

- Quando se consideram custos baixos (US\$ 0,4/árvore e US\$ 0,5/árvore), o arrendamento da terra verifica-se preferível à compra de resina no mercado. Considerando custos de produção maiores, verifica-se ser indiferente para o empresário comprar a resina ou arrendar a terra, mesmo considerando variações de até $10 \%$ nos preços atuais.

- Comparando-se a compra da terra com arrendamento, considerando-se um mesmo custo de produção, para baixas taxas de juros, verificou-se preferível a compra da terra. Já para taxas de juros superiores ( $9 \%$ e $12 \%$ a.a.), o arrendamento torna-se a melhor escolha.

- Por fim, verificou-se que a compra de resina no mercado é sempre preferível à compra da terra, a menos que as taxas de juros estejam baixas (6\% a.a.).

Outro artigo interessante, um diagnóstico mercadológico descrevendo aspectos pouco divulgados da indústria de produtos resinosos, dos problemas que ela enfrenta e das alternativas e opiniões dadas por alguns empresários e pesquisadores do setor, é apresentado por Augusto Filho (1994). Considerando alguns aspectos deste estudo, é interessante observar que grande parte das empresas que começou a comercializar resina e derivados na década de 70 e princípios da década de 80, continua a participar ativamente no setor. Analisando o espaço de tempo do período considerado, que foi de aproximadamente 15 a 20 anos, e considerando os incidentes e fases econômicas pelas quais o país passou nesse período, dir-se-ia que o setor se manteve estável em termos de entrada e saída de firmas.

A partir de 1990, o setor deparou-se com algumas diferenças decorrentes de aspectos institucionais do país, nomeadamente a abertura do Brasil aos investimentos exteriores e especificamente ligado ao setor, o início das exportações brasileiras. Torna-se importante para uma empresa presente no segmento que queira crescer ou assegurar a sua posição no setor, a garantia do fornecimento de sua matéria-prima e a venda dos seus produtos assegurada. É no 
momento atual, em que a redução de custos e o aumento das produtividades são os lemas das empresas, que se faz necessário fortalecer todos os elos da cadeia produtiva.

Utilizando material presente na bibliografia encontrada, e proveniente da pesquisa efetuada junto aos participantes do setor (resineiros ou processadores de resina), pôde-se iniciar a pesquisa sobre as formas estruturais de governança presentes no setor e suas interligações na cadeia produtiva dos produtos resinosos.

Mas, primeiro questiona-se sobre o surgimento e a evolução das empresas do setor no Brasil, como se encontra o setor atualmente e quais as considerações acerca dos parâmetros da ECT.

\subsection{A formação e evolução das empresas do setor}

Indagando sobre a formação do setor no Brasil e sobre a evolução das empresas no setor, Augusto Filho (1994) cita que o setor teve início em 1973 com a empresa Indústrias Químicas Carbomafra (atual Especialidades Químicas do Paraná), pioneira na exploração comercial e na industrialização da resina. A partir daí, outras empresas como a Harima do Paraná e a Resisul Indústrias Químicas S.A. (grupo Ultraquímica) entraram também no mercado nacional e ampliaram a resinagem com vista à produção e comercialização dos derivados da resina.

A partir de 1978, outras empresas entraram no setor, como a Eucatex Florestal Ltda., a Planebrás Comércio e Planejamento Florestais S.A., a Resitec Ind. Química Ltda., a Shell Brasil S.A., a Hoechst do Brasil Química e Farmacêutica S.A., a Hércules Brasil Produtos Químicos Ltda., e outras.

Apuraram-se três tipos de origens das empresas presentes no setor: as que vieram ou se originaram nos estágios a montante na cadeia (iniciaram-se ou surgiram a partir da floresta, base florestal); as empresas que se iniciaram dentro do segmento das resinas (expansões de empresas já existentes ou similares provenientes ou não do exterior); e as provenientes das etapas a jusante 
na cadeia (de origem em indústrias químicas que já tinham ou não contato com produtos resinosos, base química).

Assim, considerando os três tipos de origem, algumas das empresas supracitadas, como é o caso da Shell, da Hoechst, da Hércules, da Indústrias Químicas Carbomafra e da Ultraquímica (consideradas média a grande empresas), surgiram nos estágios a jusante da cadeia apresentada, eram de origem química e encaixavam-se principalmente como empresas químicas processadoras de derivados de breu ou de terebintina que verticalizaram para etapas a montante do setor das resinas com objetivos sobretudo de suprimento próprio mas também porque se apercebiam da rentabilidade que este "negócio" lhes poderia oferecer.

Outras grandes empresas, surgindo dos estágios a montante da cadeia, como a Eucatex Florestal e a Planebrás Comércio e Planejamento Florestais, entraram no segmento uma vez que possuíam as condições necessárias à entrada (florestas), tinham a capacidade financeira necessária para o investimento inicial e por todas as vantagens econômicas que obteriam das resinas.

Existem, ainda, empresas que posteriormente surgiram dentro no segmento das resinas provenientes do Brasil ou exterior e que não foram mencionadas. Estas são em maior número e de tamanho pequeno a médio.

Observa-se atualmente que algumas das grandes empresas de base química que iniciaram o setor não estão mais participando das atividades que o compõem. Este fato para as que deixaram de resinar, parece estar associado à floresta, que, na sua maioria, é arrendada de outras empresas ou entidades (Tabela 28).

Também importante é o fato dos contratos de arrendamento das florestas para a resinagem vigorar geralmente por períodos relativamente curtos (em média próximo de 3 anos, mas podendo ser menos) o que estabelece para uma grande empresa habituada a investimentos avultados um horizonte estreito de atuação. Ao fim desses anos paira sempre a ameaça do término da resinagem nessas florestas ou uma possível mudança nos arrendatários que lá resinam. 
O fato dos arrendamentos serem relativamente curtos origina sempre dúvidas quanto ao futuro da empresa resineira. Esta situação provoca mudanças freqüentes nos locais e no número de empresas presentes a resinar e causa insegurança quanto ao futuro da atividade.

Tabela 28. Algumas empresas e entidades que arrendam suas florestas no Brasil

\begin{tabular}{llc}
\hline & \multicolumn{1}{c}{$\begin{array}{c}\text { Nome/empresa } \\
1999 / 2000\end{array}$} & UF \\
\hline 1 & Alcatex & SP \\
2 & Banestado S.A Reflorestadora & PR \\
3 & Duraflora & SP, PR \\
4 & Eucatex Florestal & SP \\
5 & Faz. Santa Andréa & SP \\
6 & Fundação Florestal do Estado SP & SP \\
7 & IBAMA & Federal \\
8 & ORSA Celulose e Papel S/A & SP \\
9 & Fazenda Anaconda & SP \\
10 & Reflorestament Marquesa S/A & SP \\
11 & Pinusplan agroflorestal Ltda. & MG \\
\hline Fonte: Pesquisa do autor, 2000.
\end{tabular}

No caso específico da Shell e da Hoechst, considerando que este tipo de empresas, possuidoras das características estruturais e capacidades necessárias à integração do segmento resinas (resinagem e processamento de resina), pode-se inferir que estes abandonos do setor seriam resultado de diferentes estratégias. Corroborando esta explicação, sabe-se que estas grandes empresas químicas sofreram, no período considerado, alterações estruturais e estratégicas importantes. Talvez o segmento das resinas tenha pouca importância no total de atividades dessas empresas.

Tabela 29. Empresas que deixaram de realizar a atividade de processamento de resina nos últimos 10 anos mas que continuam operando no setor a jusante no Brasil.

\begin{tabular}{lll}
\hline & \multicolumn{1}{c}{ Nome/empresa } \\
& & U99/2000 \\
\hline 1 & Adrisyl Resinas Sintéticas S/A & SP \\
2 & Resitec Ind. Química Ltda. & RJ \\
3 & Weg Química Ltda. & SC \\
4 & Hercules do Brasil & SP \\
\hline
\end{tabular}

Fonte: Pesquisa do autor, 2000. 
É interessante observar que as empresas com este porte ou aproximado que ficaram no setor são as que mais têm contribuído em $P \& D$ na área do processamento para a evolução e aperfeiçoamento do setor.

Analise-se agora a evolução desde 1990 de acordo com dados obtidos pela pesquisa direta do autor (Tabela 29 e 30). As empresas de resinagem questionadas para o período de 1990 a 2000 parecem discordar quanto à evolução do número de suas concorrentes, já para o período de 1995 a 2000 parecem concordar numa tendência entre a estagnação e a diminuição do número de empresas.

Tabela 30. Evolução do número de empresas de resinagem segundo empresas de resinagem.

\begin{tabular}{ccccc}
\hline Período & Aumentou & Manteve-se & Diminuiu & $\begin{array}{c}\text { S/ } \\
\text { resposta }\end{array}$ \\
\hline 1990 a 2000 & $36 \%$ & $9 \%$ & $45 \%$ & $10 \%$ \\
1995 a 2000 & $9 \%$ & $27 \%$ & $45 \%$ & $19 \%$ \\
\hline
\end{tabular}

Fonte: Pesquisa do autor, 2000.

Tabela 31. Evolução do número de empresas processadoras segundo a opinião dos resineiros e das empresas processadoras de resina.

\begin{tabular}{ccccc}
\hline Período & Aumentou & Manteve-se & Diminuiu & $\begin{array}{c}\mathrm{S} / \\
\text { Resposta }\end{array}$ \\
\hline Segundo os Resineiros & & & & $18 \%$ \\
1990 a 2000 & $73 \%$ & $9 \%$ & & $18 \%$ \\
1995 a 2000 & $55 \%$ & $18 \%$ & $9 \%$ & $66 \%$ \\
Segundo as Fábricas & & & & $16,7 \%$ \\
1990 a 2000 & & $16,7 \%$ & $33,3 \%$ & $32 \%$ \\
1995 a 2000 & $33,3 \%$ & & &
\end{tabular}

Fonte: Pesquisa do autor, 2000.

Em relação às empresas de processamento de resina, questionando as empresas de resinagem, verifica-se que a maioria destas concorda num aumento significativo do número de fábricas de resina. Mas, curiosamente, este aumento não é compartilhado pelas próprias empresas de processamento de resina, estas não concordam entre si para afirmar se aumentou, diminuiu ou se manteve o número de suas similares. 
Atualmente, segundo dados provenientes da pesquisa efetuada, verifica-se que a maioria das empresas de resinagem questionadas (55\%) tem origem nas florestas, ou seja, ou trabalhava nas florestas ou possuía florestas ou realizava outras atividades nas florestas e apenas $45 \%$ se iniciaram no setor dos produtos resinosos. Já no setor processador de resina, 50\% das empresas iniciaram no setor das resinas e $50 \%$ na área química.

Concluindo, verifica-se que há cerca de 25 a 30 anos, ou seja, desde o início das atividades do setor dos produtos resinosos, no Brasil, ocorreu um crescimento gradual do setor, impulsionado sobretudo por grandes empresas do ramo químico que viam oportunidades no segmento e no mercado brasileiro e que também muitas vezes procuravam o abastecimento próprio. Outras empresas provenientes do estrangeiro, trazendo suas técnicas para o Brasil, também aproveitaram estas condições e ajudaram a formar o setor. Confrontando estas informações com dados das produções brasileiras, observa-se que somente a partir de 1990 o Brasil criou excedentes para a exportação. Recentemente, em decorrência de fatores ligados à floresta, o crescimento do número das empresas, e das produções em geral, parece estar estagnando ou diminuindo.

\subsection{Distribuição e concentração da produção}

Ferreira $^{17}$, estabelece que, do total de resina produzida no Brasil, estimada em 70 mil toneladas por ano em 1991/2, 70\% têm origem no Estado de São Paulo, dividindo-se a restante percentagem pelos Estados do Paraná, Rio de Janeiro e Minas Gerais. Cerca de 45.000 toneladas são industrializadas internamente em 17 fábricas localizadas especificamente em municípios deste Estado. As toneladas restantes (cerca de 25.000) são exportadas in natura, principalmente para Portugal, Alemanha, Índia e Argentina.

O Instituto Brasileiro de Geografia e Estatística (IBGE) publicou nas Estatísticas Florestais de 1985 dados referentes às produções de goma-resina, por municípios, em todo o

\footnotetext{
${ }^{17}$ Ferreira, op. cit., p.26.
} 
país. A goma-resina está incluída nos itens -Outros produtos florestais-, mas os dados são escassos.

A $\operatorname{ARESB}^{18}$ (1999), na qualidade de representante dos produtores de resina do Brasil, disponibiliza alguns dados sobre as produções dos seus associados. São indicados para a safra de 98/99 um total de 54 produtores de goma-resina. Destes produtores, calcula-se que aproximadamente $60 \%$ possuem áreas situadas no Estado de São Paulo, 20\% no Estado do Paraná, $8 \%$ em Minas Gerais e 5\% no Rio Grande do Sul. Deste modo, pode-se afirmar que a maioria da produção de resina natural se encontra distribuída no Estado de São Paulo. Atualmente, quando se compara com os dados de 1991 e 1998, verifica-se um aumento da produção até 1998, mas uma diminuição a partir de 1998. Apesar destas oscilações, a distribuição da produção continua indicando São Paulo como o Estado maior produtor (Figura 22).

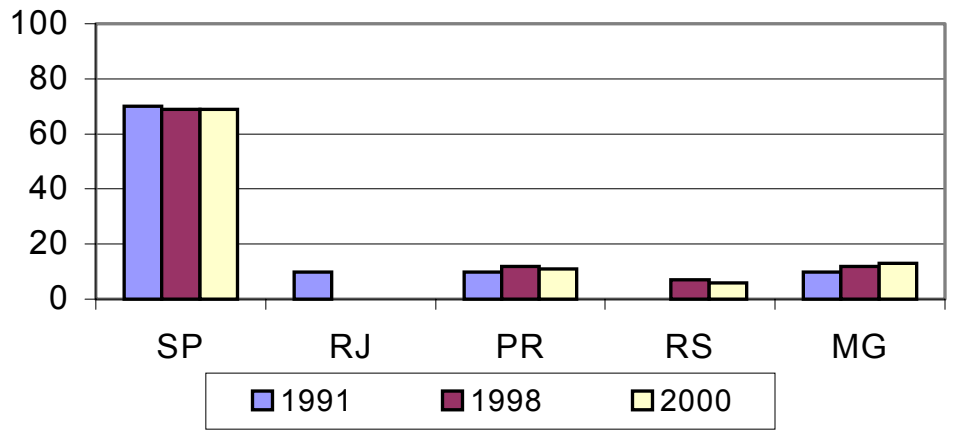

Figura 22 - Distribuição da produção por Estados 1998 e 2000 (em percentagem).

Fonte: Pesquisa do autor, 2000.

De um modo geral, a distribuição da produção, por Estado, não se alterou para os períodos considerados, verificando-se, talvez, somente uma tênue tendência de aumento das produções no Estado de Minas Gerais, como se confirma pela pesquisa de campo.

As mudanças relativas às empresas que realizam as atividades de extração de resina e processamento de resina, no Brasil, em 2000, já foram mais acentuadas (Tabelas 32 e 33). Notese a diminuição acentuada do número de empresas atuantes na extração de resina, de 1998 para 2000 (10 empresas), o que, segundo informações da ARESB e da pesquisa do autor, é decorrente da diminuição do número de áreas para resinar.

${ }^{18}$ ARESB, op. cit. p.25. 
Tabela 32. Empresas exploradoras de resina no Brasil 1998 e 2000.

\begin{tabular}{|c|c|c|c|c|c|c|}
\hline & $\begin{array}{c}\text { Nome/empresa } \\
1997 / 1998^{*}\end{array}$ & UF & $\begin{array}{l}\text { Produção } \\
\text { (Ton.) }\end{array}$ & $\begin{array}{l}\text { Nome/empresa } \\
1999 / 2000^{* *}\end{array}$ & UF & $\begin{array}{l}\text { Produção } \\
\text { (Ton.) }\end{array}$ \\
\hline 1 & Adilson Fragoso & PR & 180 & 1 Admire Agro Florestal & SP & 3220 \\
\hline 2 & Admire agroflorestal & SP & 3230 & 2 Agostinho Ferreira & SP & 400 \\
\hline 3 & Agostinho P. Ferreira & SP & 400 & 3 Agropecuária 5Mar Ltda. & SP & 1350 \\
\hline 4 & Agrícola e Sil. Selvin Ltda. & SP & 162 & 4 António Carlos Stecca & SP & 4232 \\
\hline 5 & Agropecuária 5 Mar Ltda. & SP & 1350 & 5 Areovaldo Calin Manoel & SP & 1100 \\
\hline 6 & Airton Ribeiro Machado & SP & 220 & 6 ArtPinus Resineira Ltda. & SP & 484 \\
\hline 7 & António Carlos Stecca & $\mathrm{SP}$ & 432 & 7 Atílio & PR & 400 \\
\hline 8 & António Pereira & SP & 100 & 8 Carlos A Rodrigues & SP & 460 \\
\hline 9 & António Stecca & SP & 3807 & 9 Cláudio de Nadae & $\mathrm{SP}$ & 200 \\
\hline 10 & Areovaldo Calin Manoel & SP & 1100 & 10 CMA Ind. Ltda. & $\mathrm{SP}$ & 1500 \\
\hline 11 & Artpinus Resineira Ltda. & SP & 484 & 11 Comercial Majuara & $\mathrm{SP}$ & 5503 \\
\hline 12 & Argentinos & PR & 140 & 12 Comercial Mato Verde & $\mathrm{SP}$ & 641 \\
\hline 13 & Atílio & PR & 400 & 13 Comercial Tibagi & SP & 1000 \\
\hline 14 & Carlos Rodrigues & SP & 460 & 14 Cond. Reserva Palmares & RS & 200 \\
\hline 15 & Claudinho & SP & 468 & 15 Dasotec Plan. Flor. Ltda. & PR & 600 \\
\hline 16 & Cláudio De Nadae & SP & 200 & 16 Emílio Tozoni & SP & 360 \\
\hline 17 & Claudio Mieiza & PR & 600 & 17 Faz. Holambra & SP & 1320 \\
\hline 18 & Com. Mato Verde & PR & 220 & 18 Guedes & $\mathrm{SP}$ & 1080 \\
\hline 19 & Comercial Majuara / J. Proença & $\mathrm{SP} / \mathrm{MG}$ & 8260 & 19 Habitasul Resinagem & RS & 5750 \\
\hline 20 & Comercial Tibagi Imp. Exp. & SP & 3520 & 20 Henrique Souza Fernandes & SP & 351 \\
\hline 21 & Condomínio Res. Palmares & RS & 200 & 21 Joao Schulomei & SP & 240 \\
\hline 22 & Dasotec Planej. Florest. Ltda & PR & 720 & 22 Nercilio Justino Rodrigues & SP & 500 \\
\hline 23 & Donizete & SP & 75 & 23 Osvaldo Souza Lima & SP & 2100 \\
\hline 24 & Emílio Tozoni & PR & 360 & 24 Ourives & PR & 400 \\
\hline 25 & Faz. Holambra & SP & 1320 & 25 Paracatu Faz Anaconda & SP & 1350 \\
\hline 26 & Faz. Invernadinha & SP & 250 & 26 Passareli AgroPecuária Ltda. & SP & 800 \\
\hline 27 & Faz. Santa Rita & SP & 200 & 27 Pedro Italiano & SP & 600 \\
\hline 28 & FLOPAL (Florestal Palmares) & RS & 200 & 28 Pedro Quioboa & SP & 240 \\
\hline 29 & Guedes & SP & 810 & 29 Planebrás Com. Plan. Flor. & SP & 6980 \\
\hline 30 & Habitasul Resinagem & $\mathrm{RS}$ & 5750 & 30 Raul Semedo & SP & 500 \\
\hline 31 & Harima Paraná Ind. Quim Ltda. & PR & 460 & 31 Reginaldo & $\mathrm{SP}$ & 690 \\
\hline 32 & Henrique Fernandes & SP & 351 & 32 Resilayn E. C. E. Ltda. & $\mathrm{SP} / \mathrm{MG} / \mathrm{PR}$ & 4050 \\
\hline & João Abel Schulomei & SP & 240 & 33 Resimar Ltda. & SP & 480 \\
\hline 34 & Kosegawa & $\mathrm{SP} / \mathrm{PR}$ & 1120 & 34 Resineves AgroFlorest Ltda. & $\mathrm{SP} / \mathrm{PR}$ & 6680 \\
\hline 35 & Nercílio Justino Rodrigues & SP & 500 & 35 Resinorte & MG & 300 \\
\hline 36 & Osvaldo Souza Lima & MG & 1664 & 36 Resiserv Com. Res. Ltda. & SP & 1000 \\
\hline 37 & Ourives & PR & 400 & 37 Resisul agroflorestal Ltda. & $\mathrm{SP}$ & 17705 \\
\hline 38 & Passareli Agro Pecuária Ltda & SP & 800 & 38 Resitrop Ltda. & MG & 300 \\
\hline & Pedro Italiano & SP & 600 & 39 Rosendo & SP & 660 \\
\hline 40 & Pedro Quiloba & SP & 240 & 40 Roveda & $\mathrm{SP} / \mathrm{PR}$ & 2196 \\
\hline 41 & Planebrás Com.Plan Flor. S/A & $\mathrm{SP} / \mathrm{PR}$ & 6980 & 41 S.O .Resinas Prod. Com. & SP & 480 \\
\hline & Plenavale resinagem & PR & 810 & 42 SLB & SP & 11009 \\
\hline & Raul Semedo & SP & 500 & 43 Socitec & MG & 2301 \\
\hline & Resilayn E. C. E. Ltda. & $\mathrm{SP} / \mathrm{PR} / \mathrm{MG}$ & 4050 & 44 Tomio dos Santos Kubo & $\mathrm{SP} / \mathrm{PR}$ & 1082 \\
\hline & Resimar Ltda & SP & 692 & & & \\
\hline & Resineves AgroFlorest. Ltda. & $\mathrm{SP} / \mathrm{PR}$ & 6680 & & & \\
\hline 47 & Resipinus & SP & 2300 & & & \\
\hline
\end{tabular}


Tabela 32. Empresas exploradoras de resina no Brasil 1998 e 2000.

\begin{tabular}{llcccc}
\hline $\begin{array}{l}\text { Nome/empresa } \\
1997 / 1998^{*}\end{array}$ & UF & $\begin{array}{c}\text { Produção } \\
\text { (Ton.) }\end{array}$ & $\begin{array}{l}\text { Nome/empresa } \\
1999 / 2000^{* *}\end{array}$ & $\begin{array}{c}\text { UF } \\
\text { Produção } \\
\text { (Ton.) }\end{array}$ \\
\hline $\mathbf{4 8}$ Resiserv Com. Resina Ltda.. & SP & 1600 & & \\
$\mathbf{4 9}$ Roveda & SP/PR & 2198 & & \\
$\mathbf{5 0}$ & S.O .Resinas Prod. Com. Ltda. & SP & 480 & & \\
$\mathbf{5 1}$ SLB Com. Ind. Resinas Ltda. & SP/MG & 7700 & & \\
$\mathbf{5 2}$ Tomio S. Kubo & SP/PR & 1682 & & \\
$\mathbf{5 3}$ Ultraquímica florestal Ltda. & SP & 11760 & & \\
$\mathbf{5 4}$ Valdo Tomé & PR & 242 & & \\
\hline Fonte: * ARESB, 1999 (correspondência pessoal), e ** Pesquisa do autor,1998-2000. &
\end{tabular}

Verifica-se, também, uma diminuição no número das empresas de processamento de resina, quando se compara os dados de 1991 de Ferreira ${ }^{19}$ com o levantamento deste estudo.

Tabela 33. Empresas processadoras de resina no Brasil, 1999/2000.

\begin{tabular}{lll}
\hline & \multicolumn{1}{c}{ Nome/empresa } \\
& \multicolumn{1}{c}{ U99/2000 } & \\
\hline 1 & Breuquímica Ind. Com. Ltda. & SP \\
2 & CMA Ind. Ltda. & SP \\
3 & Especialidades Quím. Paraná & PR \\
4 & Habitasul Ind. Química Ltda. & RS \\
5 & Harima do Brasil Ind. Quím. Ltda. & PR \\
6 & Resinas Brasil Ltda. & SP \\
7 & Resinas do Paraná Ltda. & PR \\
8 & Resinas Tropicais Ind. Com. Ltda. & MG \\
9 & Resinas Yser Ltda. & PR \\
10 & Resinit & SP \\
11 & Roveda Ind. Química Ltda. & SC \\
12 & Socer Brasil Ind. Com. Ltda. & SP \\
\hline
\end{tabular}

Fonte: Pesquisa do autor, 2000.

Como já se referiu anteriormente existem ainda diversas empresas que por intermédio de prestações de serviços ou por oportunidades no setor atuam comprando e vendendo produtos resinosos. Observe-se na Tabela 34 algumas que atuam exclusivamente nesta área. 
Tabela 34. Empresas do setor exclusivamente comerciais no Brasil, 1999/2000.

\begin{tabular}{lll}
\hline & \multicolumn{1}{c}{ Nome/empresa } \\
$1999 / 2000$ & UF \\
\hline 1 & DRT Brasil & SP \\
2 & Magno Imp. \& Exp. Ltda & SP \\
3 & Tecs Com. e Imp. Ltda & SP \\
4 & Resipin Com. Exp. Ltda. & SP \\
\hline
\end{tabular}

Fonte: Pesquisa do autor, 2000.

Visando uma análise da produção individual das empresas no mercado, vai-se utilizar a concentração uma vez que é forma de medida de poder de mercado mais conhecida. Esta é usualmente definida como a distribuição do número e tamanho de compradores e vendedores num mercado. Para quantificar o grau de concentração dos produtores de goma-resina no Brasil, abordam-se os dois medidores mais utilizados: a razão de concentração e o índice de HirschmanHerfindahl.

A razão de concentração é o índice mais amplamente utilizado, devido à sua maior facilidade de cálculo e de interpretação. A principal crítica a esse índice reside no fato de que não se consegue identificar quantas empresas ${ }^{20}$ (n-r) são deixadas fora do cálculo da razão de concentração e também pelo índice permanecer inalterado quando ocorrem fusões entre as (n-r) empresas deixadas fora do cálculo.

${ }^{19}$ Ferreira, op. cit., p.26.

${ }^{20}$ A razão de concentração das $k$ maiores empresas é, por definição, a proporção do valor total da produção da indústria que corresponde às $K$ maiores empresas. Seja $\mathrm{x}_{\mathrm{i}} \mathrm{o}$ valor da produção da $i$-ésima empresa e seja $\mu$ o valor médio dessa variável para as n empresas da indústria. Então, a participação da $i$ ésima empresa no valor da produção da indústria é:

$$
\mathrm{w}_{\mathrm{i}}=\mathrm{x}_{\mathrm{i}} / \mathrm{n} \mu
$$

Se as empresas estão ordenadas de maneira que

$$
\mathrm{x}_{1} \geq \mathrm{x}_{2} \geq \mathrm{x}_{3} \geq \ldots \geq \mathrm{x}_{\mathrm{n}}
$$

Então a razão de concentração das $k$ maiores empresas são:

$$
\mathrm{CR}_{\mathrm{k}}=\Sigma(\mathrm{k}, \mathrm{i}=1) \mathrm{y}_{\mathrm{i}}
$$

Já o índice de Hirschman-Herfindahl (HH) é definido por:

$$
\mathrm{HH}=\Sigma(\mathrm{n}, \mathrm{i}=1) \mathrm{y}_{\mathrm{i}}^{2}
$$

$\mathrm{O}$ valor máximo desse índice é $H H=1$ e ocorre quando a indústria é constituída por uma única empresa. $\mathrm{O}$ valor de Hirschman-Herfindahl se aproxima de zero quando todos os $y_{i}$ são diminutos, isto é, quando a produção está dividida de maneira relativamente igualitária por um grande número de empresas. 
$\mathrm{O}$ índice HH é o índice-resumo de maior prestígio, onde a ponderação da parcela de mercado de cada firma é a sua própria participação relativa na indústria.

Normalmente, espera-se que as indústrias altamente concentradas tenham desempenho pobre em termos de alocação de recursos e potencialmente possam apresentar certos tipos de conduta indesejáveis por sua capacidade de interferir nos mecanismos de formação de preços, prejudicando a concorrência. A concentração pode não garantir ausência de competição, mas os mercados mais concentrados tendem a apresentar um menor padrão competitivo. Assim, de acordo com os dados de produção de goma resina para a safra de 98/99 e 00/01 presentes na Tabela 32., construiu-se a Tabela 35., onde se encontram os índices de razão de concentração.

Tabela 35. Índice de concentração do setor produtor de resina brasileira.

\begin{tabular}{ccc}
\hline Razão de Concentração & Safra 98/99 & Safra 00/01 \\
\hline C2 & $22,42 \%$ & $31,92 \%$ \\
C4 & $38,88 \%$ & $47,11 \%$ \\
C6 & $52,81 \%$ & $58,21 \%$ \\
C & $61,61 \%$ & $66,29 \%$ \\
\hline
\end{tabular}

Fonte: Pesquisa do autor, 2000.

Verifica-se que as razões de concentração $\mathrm{C} 2$ e $\mathrm{C} 4$ não apresentam valores muito elevados. Já as razões de concentração C6 e C8 indicam que as oito maiores empresas produtoras de goma-resina representam $60 \%$ da produção total brasileira. Observa-se, igualmente, que as restantes empresas produtoras representam um percentual bastante elevado mas de produções bem distribuídas, variando ao redor de 3\% cada uma.

Trabalhando com o índice Hirschman-Herfindahl (HH), encontra-se o valor de 0,05987 para a safra de 1998 e 0,0798 para a safra de 2000, indicando que o mercado não se apresenta concentrado e contrariando a hipótese considerada de mercado concentrado.

Para o período de 1998 a 2000, verifica-se uma diminuição do número de empresas, mas não uma diminuição da produção. As razões de concentração e o índice HH durante o período de 1998 a 2000 também se elevaram um pouco apesar de não indicarem um mercado muito 
concentrado. Apesar da pouca quantidade de dados disponíveis, estes aumentos significam uma ligeira tendência para se tornar um mercado mais concentrado.

\subsection{Análise via economia de custos de transação}

Este item analisa e quantifica as características dos contratos segundo a ECT que permitem a definição e o entendimento das estruturas de governança predominantes. Vai-se inferir, igualmente, acerca de outros aspectos como as preocupações das empresas, suas opiniões, a evolução tecnológica sentida por cada um, e outros aspectos que ajudam a clarificar e a explicar os resultados.

Assim como na maioria das cadeias agro-industriais, constatou-se que os ativos são do tipo específico físico e locacional, uma vez que se trata de produtos pouco conhecidos e de características pouco conhecidas e definidas, ligadas às florestas de Pinus.

O setor e seus produtos de um modo geral são pouco conhecidos. Segundo a pesquisa efetuada, nem os próprios organismos do governo federal e estadual têm conhecimento aprofundado sobre o setor, tanto que $64 \%$ das empresas de resinagem e $67 \%$ das empresas processadoras de resina que foram questionadas, desconhece legislação estadual ou federal sobre resinagem. Somente $18 \%$ das empresas de resinagem confirma a existência de legislação sobre resinagem, mas, curiosamente, não se conseguiu apurar qual ou quais.

Considera-se ativo específico locacional, uma vez que se associa a florestas de Pinus (e somente de algumas espécies) ou a centros de indústria química específica. Nota-se que a montante a especificidade locacional é mais elevada, situando-se as empresas questionadas ou dentro da floresta (resinagem) ou a uma distância média de 170 a $225 \mathrm{Km}$ da floresta (fábricas de processamento de resina). Distância considerada próxima, atendendo à área brasileira.

Observando as empresas presentes no setor, denota-se a presença de empresas estrangeiras refletindo a recente abertura do Brasil aos investimentos estrangeiros. Este fato vem 
beneficiar grandemente o recente setor brasileiro uma vez que são introduzidas as técnicas e "know how" específicos provenientes de quase centenas de anos de atividade no estrangeiro.

Analisando a participação estrangeira nas diferentes etapas, verifica-se que é extremamente significativa. Cerca de $27 \%$ das empresas de resinagem que participaram da pesquisa possuem participações acionárias estrangeiras, sendo Portugal o principal país de origem. Relativamente às empresas processadoras de resina, a participação é maior, sendo que cerca de $83 \%$ das empresas participantes da pesquisa contêm participação estrangeira de Portugal e do Japão.

Apesar da pequena quantidade de artigos científicos publicados nos últimos 10 anos, cerca de $82 \%$ das empresas de resinagem questionadas consideram haver melhorias significativa nas técnicas empregadas.

Tabela 36. Preocupações das empresas processadoras de resina para o período de 1990 a 2000 , segundo a opinião das empresas resineiras e das empresas processadoras de resina

\begin{tabular}{lcccc}
\hline \multicolumn{1}{c}{ Preocupação da empresa } & Aumentou & Manteve-se & Diminuiu & $\begin{array}{c}\mathrm{S} / \\
\text { resposta }\end{array}$ \\
\hline $\begin{array}{l}\text { Segundo os Resineiros } \\
\text { Qualidade da goma-resina }\end{array}$ & $91 \%$ & & $9 \%$ & \\
Volume fornecido & $82 \%$ & $18 \%$ & & \\
Meio ambiente & $73 \%$ & $9 \%$ & & $18 \%$ \\
Certificação florestal & $45 \%$ & $36 \%$ & & $19 \%$ \\
$\quad \begin{array}{l}\text { Segundo as Fábricas } \\
\text { Qualidade dos produtos }\end{array}$ & $66,7 \%$ & $16,7 \%$ & & $16 \%$ \\
Volume fornecido & $67,7 \%$ & & & $32 \%$ \\
Meio ambiente e certificação & $83,3 \%$ & & & $16 \%$ \\
\hline
\end{tabular}

Fonte: Pesquisa do autor, 2000.

O desenvolvimento no setor parece ser realizado pelas empresas maiores quer de base florestal, quer de base química, agindo sobretudo em decorrência das necessidades das grandes empresas situadas no final da cadeia, a jusante. O tamanho das empresas é também fator essencial para a promoção de esforços em P\&D. Este desenvolvimento segue as exigências destas últimas empresas respeitante à qualidade da matéria-prima fornecida, aos volumes fornecidos e às emergentes questões ambientais (Tabela 36). Este padrão de comportamento está 
cada vez mais presente nos produtos agrícolas e florestais. Futuramente os produtos deverão ser certificados e as florestas sustentáveis.

O nível de especificidade física dos ativos presentes nos contratos vai aumentando ao longo da cadeia e ao longo do tempo, existindo poucas empresas que resolvam integrar todos os estágios, sobretudo os finais, em que os produtos entram dentro do campo da química fina e são em número e especificidade muito elevadas.

Tabela 37. Os mercados destino dos diversos produtos resinosos.

\begin{tabular}{lccccc}
\hline & Resina & Breu & Terebintina & $\begin{array}{c}\text { Derivados do } \\
\text { breu }\end{array}$ & $\begin{array}{c}\text { Derivados da } \\
\text { terebintina }\end{array}$ \\
\hline Mercado Regional & $58 \%$ & $31 \%$ & $38 \%$ & $50 \%$ & $40 \%$ \\
Atingem outros estados & $25 \%$ & $31 \%$ & $37 \%$ & $50 \%$ & $40 \%$ \\
Atingem outros países & $16 \%$ & $37 \%$ & $30 \%$ & & $20 \%$ \\
\hline
\end{tabular}

Fonte: Pesquisa do autor, 2000.

Nota: Considerou-se a percentagem de resultados positivos sobre o total de respostas uma vez que as empresas utilizam mais de um mercado.

Tabela 38. Mercados finais dos produtos fabricados pelas empresas de processamento de resina, considerando o total das respostas.

\begin{tabular}{lcccc}
\hline & Breu & Terebintina & $\begin{array}{c}\text { Derivados do } \\
\text { breu }\end{array}$ & $\begin{array}{c}\text { Derivados da } \\
\text { terebintina }\end{array}$ \\
\hline Mercado de tintas & $10,3 \%$ & $7,1 \%$ & $13,3 \%$ & $14,3 \%$ \\
Vernizes & $10,3 \%$ & & $13,3 \%$ & \\
Adesivos & $10,3 \%$ & & $13,3 \%$ & \\
Solventes & $2,6 \%$ & $14,3 \%$ & $6,7 \%$ & \\
Perfumaria & & $14,3 \%$ & & $28,6 \%$ \\
Borrachas & $12,8 \%$ & & $6,7 \%$ & \\
Colas papeleiras & $12,8 \%$ & & $6,7 \%$ & \\
Pastilha elástica & $5,1 \%$ & & $6,7 \%$ & \\
Tintas de impressão & $5,1 \%$ & $7,1 \%$ & $13,3 \%$ & \\
Solventes & & $14,3 \%$ & & $14,29 \%$ \\
Sabões & $12,8 \%$ & & $6,7 \%$ & \\
Desinfetantes & $2,6 \%$ & $21,4 \%$ & & $28,6 \%$ \\
Ceras & $2,6 \%$ & $7,1 \%$ & $13,3 \%$ & \\
Desconhecido, venda via "traders" & $10,3 \%$ & $7,1 \%$ & & \\
Outros mercados & $2,6 \%$ & $7,1 \%$ & & $14,2 \%$ \\
\hline Fon: Pesisa & & & \\
\hline
\end{tabular}

Fonte: Pesquisa do autor, 2000. Nota: Considerou-se a percentagem de resultados positivos sobre o total de respostas uma vez que as empresas utilizam mais de um mercado. 
Observe-se na Tabela 37 e 38 os diferentes destinos dos produtos resinosos segundo as empresas processadoras de resina questionadas. Uma vez que as empresas produzem para vários mercados finais, não foi possível apurar as percentagens dos produtos resinosos referente a cada um dos mercados finais considerados, deste modo, as percentagens consideradas indicam sobretudo quais os mercados finais mais freqüentemente abrangidos.

Verifica-se que as empresas brasileiras de produção de resina vendem na sua maioria para dentro do estado mas podendo também passar para outros estados ou mesmo exportar para outros países. Os produtores de breu e terebintina vendem de igual modo para o mesmo estado, diferentes estados, e outros países, e as empresas de derivados de breu e terebintina em iguais proporções para dentro do país, cabendo ainda, no caso dos processadores de terebintina a hipótese de exportarem para outros países.

Relativamente aos mercados finais dos produtos resinosos destacam-se os mercados de colas, borrachas, e exportação via traders para o breu, e os mercados de solventes, perfumaria e desinfetantes para a terebintina.

A característica frequência é predominantemente elevada em todos os estágios da cadeia. A quantidade de resineiros elevada, aliada ao fato das empresas processadoras de resina necessitarem de grandes quantidades mensais de resina, obriga a contatos constantes. (Tabela 39. e 40.).

É ainda fato, conhecimento geral, a existência de empresas a montante interligadas a outras a jusante por contratos ou acordos de exclusividade ou pertencendo a um mesmo grupo (sem contrato). Estes casos, por razões estratégicas das empresas ou outras, são difíceis de apurar e quantificar deixando em aberto algumas interligações importantes para o entendimento do setor.

Estas diferentes opções de sobrevivência das empresas podem ser parcialmente explicadas pela sua origem. Como se constatou anteriormente, existem três origens diferentes para as firmas do setor dos produtos resinosos: a firma de base florestal, a firma originada no segmento e a firma de base química. Estas três origens, segundo a ECT, podem determinar 
características de atuação diferentes, decorrentes das atividades e contatos que praticavam e mantinham anteriormente.

O tipo de contrato entre as empresas de resinagem e as processadoras de resina é relacionado sobretudo aos preços dos produtos resinosos e à forma de pagamento destes. De um modo geral, o pagamento da resina aos resineiros pelos processadores é efetuado à vista ou em poucos dias. Já a jusante para o breu, a terebintina e seus derivados, o pagamento dos produtos é efetuado para 30,60 ou 90 dias.

Tabela 39. Acerto dos preços da goma-resina das empresas resineiras com os compradores do ponto de vista dos resineiros

\begin{tabular}{lc} 
Tipo de acerto efetuado & $\%$ \\
\hline Fixados por curtos períodos a partir do preço de mercado & 30 \\
Fixados por longos períodos de tempo a partir do preço de mercado & 20 \\
Fixados, estabelecendo margem de lucro a partir dos custos de produção da goma-resina na floresta & 50
\end{tabular}

Fonte: Pesquisa do autor, 2000.

Nota: Considerou-se o total das respostas uma vez que as empresas utilizam mais de um mercado.

Tabela 40. Acerto dos preços da goma-resina das empresas resineiras com os compradores do ponto de vista dos processadores de resina

\begin{tabular}{lc}
\hline Tipo de acerto efetuado & $\%$ \\
\hline Fixados por curtos períodos a partir do preço de mercado & 41 \\
Fixados por longos períodos de tempo a partir do preço de mercado & 18 \\
Fixados, estabelecendo margem de lucro a partir dos custos de produção da goma-resina na floresta & 25 \\
\hline Fonte: Pesquisa do autor, 2000. & \\
Nota: Considerou-se o total das respostas uma vez que as empresas utilizam mais de um mercado.
\end{tabular}

As diferenças entre as respostas das empresas resineiras e das empresas processadoras de resina reflete o fato de que as primeiras lidam com menor número de empresas processadoras do que as segundas com as primeiras.

As empresas de resinagem fornecem, sobretudo, para uma média de três fábricas, assim assegurando as suas vendas. Por vezes realizam contratos spot, ou contratos rápidos e de menores quantidades aproveitando preços vantajosos que possam ocorrer no mercado (os preços 
dos produtos resinosos sofrem freqüentemente grandes variações). Este fato é explicado pelo pressuposto comportamental de ECT - oportunismo.

Relativamente ao parâmetro incerteza e mais propriamente o fator risco, ao analisar os estágios a montante na cadeia (base florestal), este poderia ser considerado médio. Já no segmento das resinas, mais a jusante, seria considerado mais alto devido às fortes oscilações de preços, e nas indústrias químicas (jusante), médio. Mas observem-se os resultados da pesquisa do autor relativa a esta questão nas Tabelas 41 e 42.

Tabela 41. Grau de risco financeiro atribuído pelas empresas de resinagem às diversas atividades presentes no setor dos produtos resinosos.

\begin{tabular}{lcccc}
\hline & Grande & Médio & Pequeno & S/ resposta \\
\hline Gerenciamento florestal & $9 \%$ & $9 \%$ & $27 \%$ & $55 \%$ \\
Extração de resina & $27 \%$ & $64 \%$ & & $9 \%$ \\
Compra de resina no mercado & $18 \%$ & $45 \%$ & & $37 \%$ \\
Produção de derivados breu e terebintina & & $27 \%$ & & $73 \%$ \\
Produção de derivados da terebintina & & $27 \%$ & & $73 \%$ \\
Produção de derivados do breu & & $27 \%$ & & $73 \%$ \\
\hline
\end{tabular}

Fonte: Pesquisa do autor, 2000.

Tabela 42. Grau de risco financeiro atribuído pelas empresas de processamento de resina às diversas atividades presentes no setor dos produtos resinosos.

\begin{tabular}{lcccc}
\hline & Grande & Médio & Pequeno & S/ resposta \\
\hline Gerenciamento florestal & $17 \%$ & $17 \%$ & $17 \%$ & $50 \%$ \\
Extração de resina & $33 \%$ & $17 \%$ & & $50 \%$ \\
Compra de resina no mercado & $33 \%$ & $50 \%$ & $17 \%$ & \\
Produção de derivados breu e terebintina & & $50 \%$ & & $50 \%$ \\
Produção de derivados da terebintina & & $50 \%$ & & $50 \%$ \\
Produção de derivados do breu & & $50 \%$ & & $50 \%$ \\
\hline
\end{tabular}

Fonte: Pesquisa do autor, 2000.

É importante considerar para a atividade de resinagem o fato de esta se basear em florestas arrendadas em que os períodos de arrendamento são relativamente curtos (aproximadamente 3 anos). Fica sempre a dúvida quanto ao futuro da empresa arrendatária uma vez que pode originar (e origina) a mudança de empresas por floresta, causando uma insegurança grave quanto ao futuro da atividade. 
Observa-se que a maioria das empresas de resinagem considera a atividade de extração de resina uma atividade de risco financeiro médio a alto. A atividade a montante de gerenciamento florestal, de médio a pequeno risco, e as atividades a jusante, desde a compra de goma-resina no mercado ao processamento de goma-resina e seus derivados, de risco financeiro médio. As empresas de processamento de resina parecem também considerar as atividades extração de resina, de médio a alto risco financeiro, as atividades a montante são indefinidas e as atividades a jusante na cadeia, de médio risco, à parte a compra de goma que é considerada de médio a alto.

Por meio da pesquisa direta efetuada junto às empresas sobre suas expectativas futuras relativamente à sua atividade, notou-se, para a operação de resinagem, que as opiniões divergiam. Como se pode observar na Tabela 43, as respostas são muitas, revelando uma certa indefinição geral quanto ao futuro da atividade. Já para a operação de processamento de resina as empresas questionadas, de um modo concordante, parecem acreditar no crescimento e potencialidade da atividade.

Tabela 43. Resultados da auto-avaliação das empresas de resinagem e processamento de resina sobre suas próprias atividades.

\begin{tabular}{lcc}
\hline & Op. Resinagem & $\begin{array}{c}\text { Op. Processamento de } \\
\text { resina }\end{array}$ \\
\hline Em expansão & $27 \%$ & $67 \%$ \\
Em expansão mas sem potencialidades & $18 \%$ & $33 \%$ \\
Estagnada com potencialidades & $9 \%$ & \\
Estagnada sem potencialidades & $18 \%$ & \\
Em decadência com potencialidades & $18 \%$ & \\
Em decadência & & \\
\hline
\end{tabular}

Fonte: Pesquisa do autor 2000.

Estas freqüentes divergências de opiniões por parte das empresas do setor parecem sugerir ações derivadas do pressuposto comportamental da ECT -racionalidade limitadapois, freqüentemente, certos tipos de atividade são considerados complexos e arriscados para algumas empresas mas para outras não. Com certeza algumas destas empresas está agindo ineficientemente. Observando os parâmetros de ECT esta divergências ou incertezas quanto ao mercado vêm complementar o fator risco. 
Finalizando, verifica-se que a cadeia que compreende o setor das resinas é uma cadeia extensa e variada em termos de tipos de contratos. Estão presentes nesta cadeia variados tipos de empresas, confirmando-se a presença dos três tipos padrão de empresas: as empresas de base florestal; empresas originárias do setor resineiro e empresas de base química.

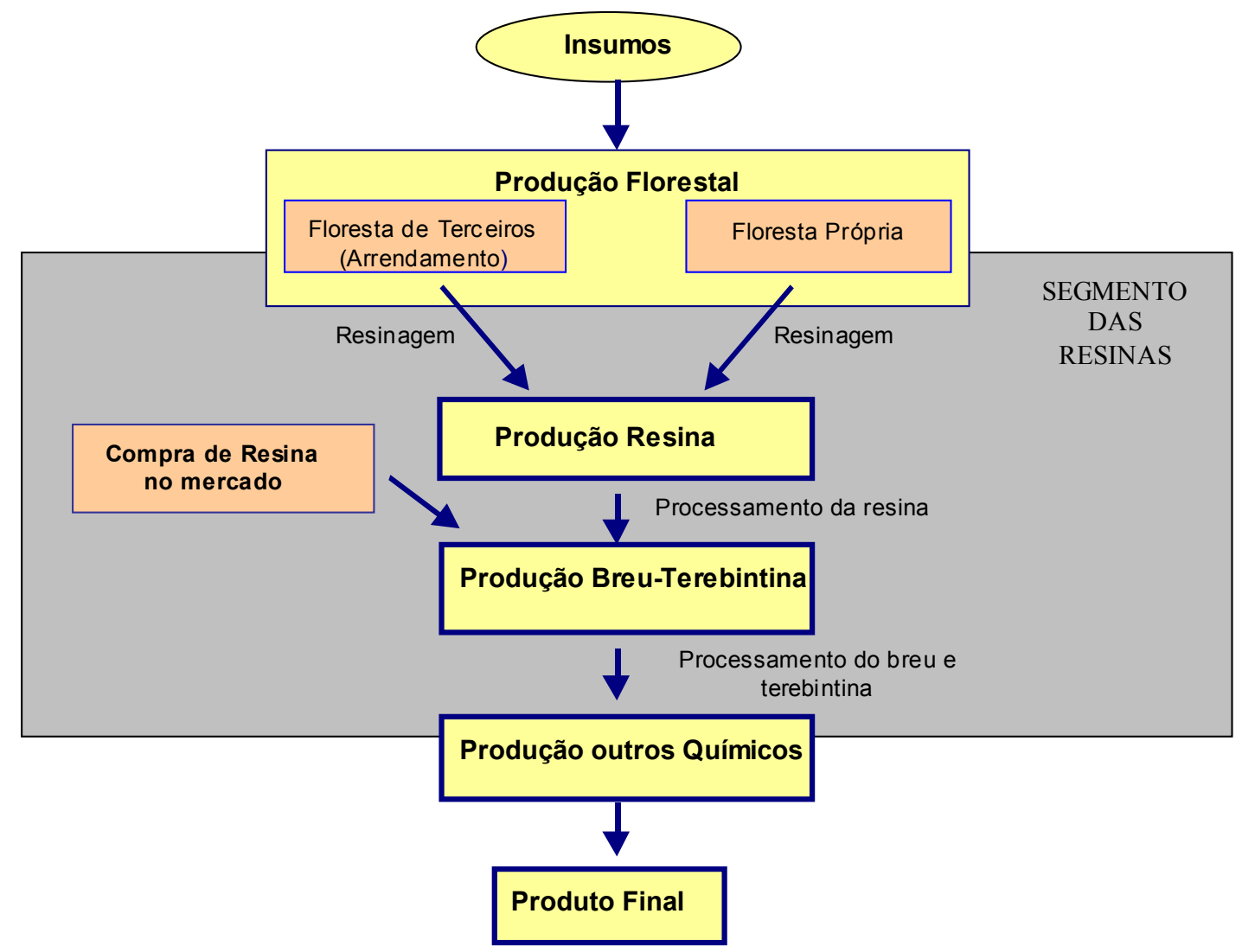

Figura 23 - Cadeia produtiva dos produtos resinosos.

Fonte: Pesquisa do autor, 2000.

As empresas do setor procuram se adaptar ao mercado e expandir sempre que possível. $\mathrm{Na}$ sua maioria, as empresas questionadas integram outras etapas/atividades dentro da cadeia dos produtos resinosos.

Segundo resultados da pesquisa, constata-se, relativamente às empresas de resinagem, que responderam aos questionários, que 36\% destas realizam atividades paralelas na área de 
gerenciamento de florestas, $9 \%$ na área de processamento de resina e $9 \%$ na área do processamento de derivados de resina.

Já relativamente às empresas processadoras de resina, atendendo ao número de empresas questionadas, $17 \%$ destas realizam atividades na área de gerenciamento florestal, 17\% realizam a atividade de resinagem (os mesmos 17\%) e finalmente 50\% destas últimas realizam também processamento de derivados de resina, ou seja, processamento do breu e da terebintina para obtenção de outros químicos.

De um modo geral, analisando a evolução do setor, pode-se notar um movimento de integração entre as empresas de base florestal para o segmento das resinas, aproveitando o fato de terem disponibilidade de florestas e portanto, de matéria prima e dos extensivos contatos com o meio florestal, facilitando o estabelecimento de arrendamentos em outras florestas. A maioria destas continua exercendo atividades ligadas à floresta fora do segmento das resina.

Já as empresas de base química, e analisando a sua evolução e respostas à pesquisa, não apresentam tendência para a integração total na cadeia. Ainda assim, procurarão assegurar o fornecimento, pelo menos parcial, da sua matéria prima através da realização de contratos de longo prazo ou de exclusividade, observando-se deste modo a hipótese considerada inicialmente.

As características da ECT analisadas parecem indicar a verticalização como uma opção importante a ser seguida por algumas empresas do setor. No entanto, formas híbridas de mercado parecem ser as que mais serão mantidas. Haverá, dependendo da origem das empresas, tendência para várias estruturas de governança.

Seguindo o curso da cadeia, as unidades de processamento poderão estar integradas em empresas que produzem outros produtos químicos (derivados do breu e terebintina) e, em alguns casos, o produto final que é oferecido aos consumidores. Estas empresas têm um papel extremamente importante no setor uma vez que garantem o consumo dos produtos imediatamente abaixo na cadeia, diminuindo a predominância da alternativa chinesa. 


\section{CONCLUSÕES}

De um modo geral, constata-se que o setor, desde o seu surgimento, tem crescido significativamente, aproximando-se, nestes últimos anos, de um patamar relativamente estável em que são colmatadas as exigências do mercado interno e em que se dão os difíceis passos no mercado mundial. Este mercado é dominado pela China que, com produções equivalentes a $65 \%$ da produção mundial, estabelece preços inversamente proporcionais à quantidade de mão-deobra que tem disponível.

Analisando a estrutura dos custos de produção para as operações de resinagem e processamento de resina, notou-se, relativamente à primeira, uma importante participação dos custos derivados da mão-de-obra. Constata-se que esta é uma operação mão-de-obra intensiva, sendo os custos correspondentes, considerados de grande importância pela maioria $(100 \%$ de concordância) das empresas questionadas. São também considerados importantes os custos de instalação, os custos de comercialização e os custos derivados de questões ambientais. Quanto aos restantes custos, de materiais diretos, de funcionamento fixo, e de arrendamento das florestas não se perceberam níveis de importância significativos para a operação.

Apesar das muitas preocupações das empresas questionadas, não se notaram níveis críticos relacionados a custos na operação de resinagem como sucede atualmente em outros países produtores de resina.

Relativamente à operação de processamento de resina, os seus custos não diferem dos de uma indústria química brasileira de primeiros estágios. Os itens de custos encontram-se bem distribuídos. É interessante notar uma estreita ligação, quase dependência, entre este tipo de empresa e as empresas a montante de resinagem. 
Analisando o surgimento do setor, conclui-se que este se deve essencialmente a esforços de grandes empresas químicas e florestais que, observando as hipóteses e potencialidades do segmento resinas, verticalizaram suas operações a montante e a jusante.

Atualmente, identificam-se três origens das empresas presentes no setor dos produtos resinosos: as provenientes de etapas a montante na cadeia que são $55 \%$ das empresas de resinagem, as empresas que surgiram dentro do setor (por expansão de outras ou provenientes do exterior) que respondem por $45 \%$ das empresas de resinagem e $50 \%$ das empresas de processamento, e as empresas provenientes de etapas a jusante que são $50 \%$ das empresas de processamento.

Em termos de evolução do número de empresas nos últimos 5 e 10 anos, apesar de uma certa discordância por parte das empresas participantes da pesquisa, verifica-se uma constância ou leve diminuição do número de empresas de resinagem e um ligeiro aumento do número de fábricas processadoras de resina.

Acerca da distribuição do setor, pode-se concluir que a produção do setor encontra-se situada essencialmente no Estado de São Paulo, com cerca de $65 \%$ da produção brasileira, e pelos Estados do Paraná, Rio Grande do Sul e Minas Gerais, equilibrando-se com os restantes 35\%. Analisando dados de 1993, 1998 e 2000, esta distribuição pouco se altera, notando-se apenas uma ligeira tendência de subida de produção do Estado de Minas Gerais.

Já em termos de concentração de mercado, utilizando as razões de concentração $(C 2, C 4$, C6, e C8) e o índice de Hirshman-Herfindhal (HH) para os anos de 1998 e 2000 verifica-se que o mercado, ao contrário do que se pressupunha, não se encontra muito concentrado. Para o período considerado, constata-se um ligeiro aumento da concentração, situando as participações das 2, 4, 6, e 8 maiores empresas em 31, 47, 58 e 66\% da produção brasileira e o índice HH em 0,0798 .

Analisando a cadeia dos produtos resinosos, através dos parâmetros de ECT, constata-se que os produtos resinosos são do tipo específico locacional, atendendo às suas características peculiares e à floresta de Pinus de onde são originados. O parâmetro incerteza associado ao fator risco, segundo a pesquisa, é considerado de médio a elevado e a freqüência, elevada para todas 
as etapas analisadas. Relativamente a estes parâmetros, verificaram-se muitas incertezas quanto a questões pertinentes da análise, indicando a pertinência dos pressupostos comportamentais, racionalidade limitada e oportunismo.

Os parâmetros parecem indicar a forma híbrida das estruturas de governança como a predominante no setor. De fato, o setor parece apresentar a tendência de estruturas de governança de uma cadeia agro-industrial normal, surgindo o mercado nos estágios a montante, no início da cadeia e tendendo ao longo da cadeia sentido jusante para situações hierarquizadas.

Do ponto de vista das empresas do setor, considerando que o mercado a montante é relativamente pequeno e complexo, com os parâmetros incerteza e freqüência altos, há tendências de verticalização das empresas químicas de processamento de derivados, para montante, garantindo pelo menos parcialmente suas matérias-primas e explicando então as formas híbridas. As empresas de base florestal parecem sentir os mesmos estímulos (disponibilidade de florestas) desde o surgimento do setor.

Espera-se que, a partir deste trabalho, novos estudos descrevam as relações que determinam o comportamento do mercado nacional e internacional contribuindo-se, assim, para o desenvolvimento do setor de produtos resinosos brasileiros. 
ANEXOS 


\section{QUESTIONÁRIO A}

Nome do entrevistado:

Empresa:

Cargo:

Telefone e fax:

LEIA ATENTAMENTE O QUESTIONÁRIO. AS SUAS RESPOSTAS DEVEM SE RESTRINGIR A SUA EMPRESA. SE TIVER ALGUMA DÚVIDA, ENTRAR EM CONTATO COM JOSÉ FERREIRA. AS INFORMAÇÕES OBTIDAS NESTE QUESTIONÁRIO DESTINAM-SE EXCLUSIVAMENTE PARA FINS ACADÊMICOS.

\section{Marque um $X$ nas atividades que a sua empresa realiza no setor dos produtos resinosos:}

Gerenciamento de florestas

Resinagem

Processamento de goma-resina

Processamento de derivados de goma-resina

Outras

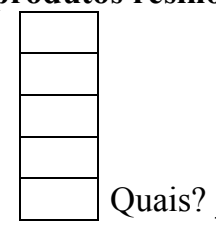

2. Qual a origem da sua empresa ou do grupo em que se insere a sua empresa: (marque um $X$ )

Florestal (trabalhava na área florestal ou possuía florestas, etc.)

Resineira (sempre trabalhou no setor de resinas)

Química (iniciada na química viu oportunidade no setor resinas)

Outra

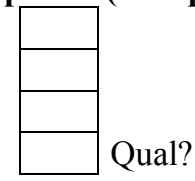

3. A sua empresa tem participação estrangeira? (marque um $X$ )

Sim
Não De que países?

4. Marque um $X$ de acordo com o grau de risco financeiro que considera para as atividades:

Gerenciamento florestal

Extração de resina

Compra de resina no mercado

Produção de derivados breu e terebintina

Produção de derivados da terebintina

Produção de derivados do breu

Outros do segmento, qual?

\begin{tabular}{|c|c|c|c|c|}
\hline Grande & Médio & Pequeno & Nenhum & $\begin{array}{c}\text { Sem } \\
\text { observações }\end{array}$ \\
\hline & & & & \\
\hline & & & & \\
\hline & & & & \\
\hline & & & & \\
\hline & & & & \\
\hline & & & & \\
\hline & & & & \\
\hline
\end{tabular}

\section{RELATIVAMENTE À RESINAGEM:}

5. Na sua região, a resinagem é uma atividade: (marque um $X$ )

Em expansão

Em expansão mas sem potencialidades

Estagnada com potencialidades

Estagnada sem potencialidades

Em decadência com potencialidades

Em decadência

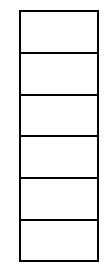

6. Existe ou conhece alguma legislação federal ou estadual específica sobre resinagem? (leis, normas, portarias, etc.) 
PREENCHA O QUADRO COM DADOS POR ÁREA RESINADA:

7. Nome do município e estado

8. Marque um $X$ nas áreas que são propriedade própria

9. Qual a área total da floresta

10. Quais as atividades principais da floresta que resina (serraria, aglomerados, carvão, papel, etc.)

11. Qual a espécie de Pinus predominante

12. Qual o número de faces resinadas

13. Qual a produção anual de goma-resina

14. Qual a média de árvores por hectare

15. Quais as produtividades (Kg / face / ano)

16. Qual a idade média da floresta

17. Quantos funcionários tem na floresta

18. Faça uma média da distâncias da floresta até as fábricas

19. Como são efetuados os transportes da goma-resina (carreta ou caminhão)

20. Possui transportes próprios da goma-resina para as fábricas?

\begin{tabular}{|l|l|l|l|l|}
\hline & & & & \\
\hline & & & & \\
\hline & & & & \\
\hline & & & & \\
\hline & & & & \\
\hline & & & & \\
\hline & & & & \\
\hline & & & & \\
\hline & & & & \\
\hline
\end{tabular}

21. Fornece resina para quais fábricas?

22. Em que regiões (estados) prevê novas áreas para resinar?

23. Marque um X no mercado para qual sua resina é vendida, se possível indique em percentagens:

Mercado Regional

Atingem outros estados

Atingem outros países

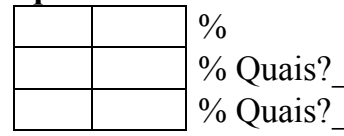

24. Na sua opinião acha que o número de pessoas resinando ou empresas de resinagem: (marque um X)

Nos últimos 10 anos

Nos últimos 5 anos

\begin{tabular}{|l|l|l|}
\hline Aumentou & Manteve-se & Diminuiu \\
\hline & & \\
\hline & & \\
\hline
\end{tabular}

25. Na sua opinião acha que o número de fábricas a receber goma-resina: (marque um X)

Nos últimos 10 anos

Nos últimos 5 anos

\begin{tabular}{|l|l|l|}
\hline Aumentou & Manteve-se & Diminuiu \\
\hline & & \\
\hline & & \\
\hline
\end{tabular}

26. Como são acertados os preços da goma-resina com os compradores? (marque um $X$ )

São fixados por curtos períodos (15 dias aproximadamente) a partir do preço de mercado

São fixados, via contrato, por longos períodos de tempo a partir do preço de mercado

São fixados, via contrato, estabelecendo margem de lucro a partir dos custos de produção da goma-resina na floresta 
27. Marque um $X$ de acordo com o grau de importância que considera para os problemas da sua atividades:

A falta de florestas ou áreas para resinar

Falta de mão-de-obra

Os preços dos produtos no mercado mundial

Produtos concorrentes (resina sintética, etc..)

Impostos

Transportes (fretes, gasolina, manutenções de ônibus, etc..)

Legislação trabalhista complexa

A concorrência

A falta de incentivos ou outro tipo de ajudas do governo

Gerenciamentos e burocracias

Os custos dos materiais empregados (estimulantes, sacões, etc..)

Outro:

\begin{tabular}{|c|c|c|c|}
\hline $\begin{array}{c}\text { Muito } \\
\text { importante }\end{array}$ & Importante & $\begin{array}{c}\text { Pouco } \\
\text { importante }\end{array}$ & $\begin{array}{c}\text { Sem } \\
\text { observações }\end{array}$ \\
\hline & & & \\
\hline & & & \\
\hline & & & \\
\hline & & & \\
\hline & & & \\
\hline & & & \\
\hline & & & \\
\hline & & & \\
\hline & & & \\
\hline & & & \\
\hline & & & \\
\hline & & & \\
\hline
\end{tabular}

28. Quais os CUSTOS que considera mais importantes? Marque um X de acordo com o grau de importância:

Custos de instalação (veículos, acampamentos, licenças, treinamentos, etc.)

Custos dos materiais diretos (limpezas na florestas, uniformes, pasta, sacões, etc.)

Custos de comercialização (fretes, impostos de comercialização, financeiros, etc.)

Custos de mão de obra direta (pagamentos, gerenciamentos, encargos sociais, etc.)

Custos fixos de funcionamento (Transporte de funcionários, manutenções, impostos, etc.)

Custos com o arrendamento das florestas

Custos derivados de questões ambientais

Outros:

\begin{tabular}{|l|l|c|c|}
\hline $\begin{array}{c}\text { Muito } \\
\text { importante }\end{array}$ & Importante & $\begin{array}{c}\text { Pouco } \\
\text { importante }\end{array}$ & $\begin{array}{c}\text { Sem } \\
\text { observações }\end{array}$ \\
\hline & & & \\
\hline & & & \\
\hline & & & \\
\hline & & & \\
\hline & & & \\
\hline & & & \\
\hline & & & \\
\hline & & & \\
\hline
\end{tabular}

29. Dentre os CUSTOS DE INSTALAÇÃO, quais os que considera mais importantes? Marque um $X$ de acordo com o grau de importância:

Custos das máquinas/veículos

Custos com equipamentos, utensílios, etc..

Custos imobiliários de formação de, acampamentos, escritórios etc..

Custos com impostos específicos, licenças, burocracias, etc.

Custos com treinamentos

Outros:

\begin{tabular}{|c|c|c|c|}
\hline $\begin{array}{c}\text { Muito } \\
\text { importante }\end{array}$ & Importante & $\begin{array}{c}\text { Pouco } \\
\text { importante }\end{array}$ & $\begin{array}{c}\text { Sem } \\
\text { observações }\end{array}$ \\
\hline & & & \\
\hline & & & \\
\hline & & & \\
\hline & & & \\
\hline & & & \\
\hline & & & \\
\hline
\end{tabular}

30. Dentre os CUSTOS DE MATERIAIS DIRETOS, quais os que considera mais importantes? Marque um X de acordo com o grau de importância:

Custos com manutenções, limpezas, roçadas, etc.. da floresta Custos com uniformes, calçados, material de trabalho, EPI's, etc. Custos com embalagens, sacões, saquinhos, pasta estimulante, etc. Outros:

\begin{tabular}{|c|c|c|c|}
\hline $\begin{array}{c}\text { Muito } \\
\text { importante }\end{array}$ & Importante & $\begin{array}{c}\text { Pouco } \\
\text { importante }\end{array}$ & $\begin{array}{c}\text { Sem } \\
\text { observações }\end{array}$ \\
\hline & & & \\
\hline & & & \\
\hline & & & \\
\hline & & & \\
\hline
\end{tabular}


31. Dentre os CUSTOS DE COMERCIALIZAÇÃO, quais os que considera mais importantes? Marque um $X$ de acordo com o grau de importância:

Custos com impostos de comercialização (ICMS, PIS, CONFINS)

Custos com quebras de estoque

Custos de fretes da goma-resina

Custos financeiros

Outros:

\begin{tabular}{|c|l|c|c|}
\hline $\begin{array}{c}\text { Muito } \\
\text { importante }\end{array}$ & Importante & $\begin{array}{c}\text { Pouco } \\
\text { importante }\end{array}$ & $\begin{array}{c}\text { Sem } \\
\text { observações }\end{array}$ \\
\hline & & & \\
\hline & & & \\
\hline & & & \\
\hline & & & \\
\hline & & & \\
\hline
\end{tabular}

32. Dentre os CUSTOS COM MÃO DE OBRA DIRETA, quais os que considera mais importantes? Marque um $X$ de acordo com o grau de importância:

Custos com a folha de pagamentos

Custos com impostos e encargos sociais (INSS)

Custos derivados da legislação trabalhista (CIPA, etc.)

Custos da administração

Outros:

\begin{tabular}{|c|c|c|c|}
\hline $\begin{array}{c}\text { Muito } \\
\text { importante }\end{array}$ & Importante & $\begin{array}{c}\text { Pouco } \\
\text { importante }\end{array}$ & $\begin{array}{c}\text { Sem } \\
\text { observações }\end{array}$ \\
\hline & & & \\
\hline & & & \\
\hline & & & \\
\hline & & & \\
\hline & & & \\
\hline
\end{tabular}

33. Dentre os CUSTOS DE FUNCIONAMENTO, quais os que considera mais importantes? Marque um $X$ de acordo com o grau de importância:

Custos com vigilância e segurança

Custos de transportes de funcionários

Custos com depreciação de imóveis e equipamentos

Custos com honorários contábeis e jurídicos

Custos com impostos específicos, taxas e juros

Custos com manutenções e reformas

Custos com Gasolinas e lubrificantes

Outros:

\begin{tabular}{|c|l|c|c|}
\hline $\begin{array}{c}\text { Muito } \\
\text { importante }\end{array}$ & Importante & $\begin{array}{c}\text { Pouco } \\
\text { importante }\end{array}$ & $\begin{array}{c}\text { Sem } \\
\text { observações }\end{array}$ \\
\hline & & & \\
\hline & & & \\
\hline & & & \\
\hline & & & \\
\hline & & & \\
\hline & & & \\
\hline & & & \\
\hline & & & \\
\hline
\end{tabular}

34. Nos últimos 10 anos, as preocupações das empresas compradoras da sua goma-resina relacionadas com: (marque um X)

A Qualidade da goma-resina

O volume fornecido de goma-resina

O Meio ambiente

A certificação florestal

\begin{tabular}{|l|l|l|}
\hline Aumentaram & Mantiveram & Diminuíram \\
\hline & & \\
\hline & & \\
\hline & & \\
\hline & & \\
\hline
\end{tabular}

35. Nos últimos 10 anos, considera que:

Há melhorias significativas nas técnicas de resinagem.

Não há melhorias significativas

36. Acha que as necessidades e interesses da sua atividade são bem compreendidos e estão bem defendidos junto às entidades governamentais e estaduais? 
Nome do entrevistado:

Empresa:

Cargo:

Telefone e fax:

LEIA ATENTAMENTE O QUESTIONÁRIO. AS SUAS RESPOSTAS DEVEM SE RESTRINGIR A SUA EMPRESA. SE TIVER ALGUMA DÚVIDA, ENTRAR EM CONTATO COM JOSÉ FERREIRA. AS INFORMAÇÕES OBTIDAS NESTE QUESTIONÁRIO DESTINAM-SE EXCLUSIVAMENTE PARA FINS ACADÊMICOS.

1. Marque um $X$ nas atividades que a sua empresa realiza no setor dos produtos resinosos:

Gerenciamento de florestas

Resinagem

Processamento de goma-resina

Processamento de derivados de goma-resina

Outras

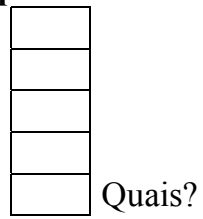

2. Qual a origem da sua empresa ou do grupo em que se insere a sua empresa: (marque um $\mathrm{X}$ )

Florestal (trabalhava na área florestal ou possuía florestas, etc.)

Resineira (sempre trabalhou no setor de resinas)

Química (iniciada na química viu oportunidade no setor resinas)

Outra

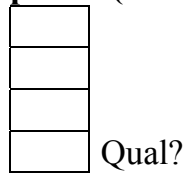

3. A sua empresa tem participação estrangeira? (marque um X)

Sim De que países?

Não

4. Marque um $X$ de acordo com o grau de risco financeiro que considera para as atividades:

Gerenciamento florestal

Extração de resina

Compra de resina no mercado

Produção de derivados breu e terebintina

Produção de derivados da terebintina

Produção de derivados do breu

Outros do segmento, qual?

\begin{tabular}{|c|c|c|c|c|}
\hline Grande & Médio & Pequeno & Nenhum & $\begin{array}{c}\text { Sem } \\
\text { observações }\end{array}$ \\
\hline & & & & \\
\hline & & & & \\
\hline & & & & \\
\hline & & & & \\
\hline & & & & \\
\hline & & & & \\
\hline & & & & \\
\hline
\end{tabular}

RELATIVAMENTE AO PROCESSAMENTO DE RESINA OU DE DERIVADOS:

5. Considera a sua atividades com os produtos resinosos:

Em expansão

Em expansão mas sem potencialidades

Estagnada com potencialidades

Estagnada sem potencialidades

Em decadência com potencialidades

Em decadência

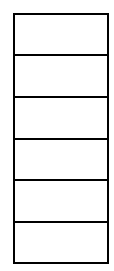

7. Acha que as necessidades e interesses da sua atividade são bem compreendidos e estão bem defendidos junto às entidades governamentais e estaduais? 
PREENCHA O QUADRO COM DADOS DO(S) PRODUTO(S) RESINOSO(S) QUE VOCÊ PROCESSA, INDIQUE:

7. As quantidades normalmente processadas (ton./ano)

8. As quantidades máximas de processamento (ton./ano)

9. Quais são provenientes de fornecedores exclusivos, se possível indicar em que percentagem

9A. A distância média percorrida até a sua fábrica $(\mathrm{Km})$

10. O número aproximado de produtos que este origina na sua fábrica

11. Tipo de transporte utilizado no recebimento

12. Em quais produtos os transportes são próprios ou exclusivos.

\begin{tabular}{|l|l|l|l|l|l|}
\hline Resina & Breu & $\begin{array}{c}\text { Breu de } \\
\text { taloil }\end{array}$ & Terebintina & $\begin{array}{c}\text { Terebintina } \\
\text { Sulfatada }\end{array}$ & Outros \\
\hline & & & & & \\
\hline & & & & & \\
\hline & & & & & \\
\hline & & & & & \\
\hline & & & & & \\
\hline & & & & & \\
\hline & & & & & \\
\hline
\end{tabular}

PREENCHA O QUADRO COM DADOS DO(S) PRODUTO(S) RESINOSO(S) QUE VOCÊ FABRICA, INDIQUE:

13. As Quantidades normalmente produzidas (ton./ano)

14. O número de produtos (no caso dos derivados)

15. O número aproximado de clientes

\begin{tabular}{|l|l|l|l|l|}
\hline Breu & Terebintina & $\begin{array}{c}\text { Derivados do } \\
\text { breu }\end{array}$ & $\begin{array}{c}\text { Derivados da } \\
\text { terebintina }\end{array}$ & Outros \\
\hline & & & & \\
\hline & & & & \\
\hline & & & & \\
\hline
\end{tabular}

16. Marque um $X$ no mercado para qual os seus produtos são vendidos, se possível indique em percentagens:

Mercado Regional

Atingem outros estados

Atingem outros países

\begin{tabular}{|l|c|c|c|c|}
\hline Breu & Terebintina & $\begin{array}{c}\text { Derivados do } \\
\text { breu }\end{array}$ & $\begin{array}{c}\text { Derivados da } \\
\text { terebintina }\end{array}$ & Outros \\
\hline & & & & \\
\hline & & & & \\
\hline & & & & \\
\hline
\end{tabular}

17. Marque um $X$ nos mercados finais dos produtos que fabrica, se possível indique em percentagens.

Mercado de tintas

Vernizes

Adesivos

Solventes

Perfumaria

Borrachas

Colas papeleiras

Pastilha elástica

Tintas de impressão

Solventes

Sabões

Desinfetantes

Cêras

Desconhecido, venda via "traders"

Outros

\begin{tabular}{|l|l|l|l|l|}
\hline Breu & Terebintina & $\begin{array}{c}\text { Derivados do } \\
\text { breu }\end{array}$ & $\begin{array}{c}\text { Derivados da } \\
\text { terebintina }\end{array}$ & Outros \\
\hline & & & & \\
\hline & & & & \\
\hline & & & & \\
\hline & & & & \\
\hline & & & & \\
\hline & & & & \\
\hline & & & & \\
\hline & & & & \\
\hline & & & & \\
\hline & & & & \\
\hline & & & & \\
\hline & & & & \\
\hline & & & & \\
\hline & & & & \\
\hline
\end{tabular}


18. Como são acertados os preços com os seus fornecedores? (marque um $X$ )

São fixados por curtos períodos (15 dias aproximadamente) a partir do preço de mercado

São fixados, via contrato, por longos períodos de tempo a partir do preço de mercado

São fixados, via contrato, estabelecendo margem de lucro a partir dos custos de produção

19. Nos últimos 10 anos, as preocupações das empresas consumidoras dos seus produtos relacionadas com: (marque um X)

A qualidade dos produtos

$\mathrm{O}$ volumes fornecidos

O Meio-ambiente e certificação

\begin{tabular}{|l|l|l|}
\hline Aumentaram & Mantiveram & Diminuíram \\
\hline & & \\
\hline & & \\
\hline & & \\
\hline
\end{tabular}

20. Na sua opinião acha que o número de empresas que atua no seu ramo de atividade: (marque um $X$ )

Nos últimos 10 anos

Nos últimos 5 anos

\begin{tabular}{|l|l|l|}
\hline Aumentou & Manteve-se & Diminuiu \\
\hline & & \\
\hline & & \\
\hline
\end{tabular}

21. Marque um $X$ de acordo com o grau de importância que considera para os problemas da sua atividades:

O fornecimento de matéria prima

Preços da matéria prima (valores, instabilidade)

Preços do mercados externo

Os produtos concorrentes

Os fretes e transportes

Os impostos

A legislação trabalhista

Os produtos importados

Os materiais e insumos utilizados

A falta de incentivos ou outro tipo de ajudas do governo

Os custos de produção de um modo geral

Outro:

\begin{tabular}{|l|l|l|l|}
\hline $\begin{array}{c}\text { Muito } \\
\text { importante }\end{array}$ & Importante & $\begin{array}{c}\text { Pouco } \\
\text { importante }\end{array}$ & $\begin{array}{c}\text { Sem } \\
\text { observações }\end{array}$ \\
\hline & & & \\
\hline & & & \\
\hline & & & \\
\hline & & & \\
\hline & & & \\
\hline & & & \\
\hline & & & \\
\hline & & & \\
\hline & & & \\
\hline & & & \\
\hline & & & \\
\hline & & & \\
\hline
\end{tabular}

22. Relativamente aos CUSTOS da sua atividades. Marque um $X$ de acordo com o grau de importância:

Custos de instalação ("know how", montagem, infraestruturas, equipamentos, veículos, treinamentos, etc.)

Custos dos materiais diretos (matéria prima processadas, insumos, uniformes e EPI's, material de embalagem, etc.)

Custos de comercialização (representações, fretes, impostos de comercialização, financeiros, etc.)

Custos de mão de obra direta (pagamentos, encargos sociais, obrigações trabalhistas, etc.)

Custos fixos de funcionamento (Transporte de funcionários, manutenções, impostos, licenças, etc.)

Custos administrativos ou gerenciais

Custos derivados de programas de qualidade (auditorias, consultorias, etc.)

Custos derivados de questões ambientais (efluentes, resíduos, etc.)

Outros:

\begin{tabular}{|l|l|l|c|}
\hline $\begin{array}{c}\text { Muito } \\
\text { importante }\end{array}$ & Importante & $\begin{array}{c}\text { Pouco } \\
\text { importante }\end{array}$ & $\begin{array}{c}\text { Sem } \\
\text { observações }\end{array}$ \\
\hline & & & \\
\hline & & & \\
\hline & & & \\
\hline & & & \\
\hline & & & \\
\hline & & & \\
\hline & & & \\
\hline & & & \\
\hline & & & \\
\hline
\end{tabular}




\section{REFERÊNCIAS BIBLIOGRÁFICAS}

AGUIAR, D.R.D. A questão da transmissão de preços agrícolas. Revista de Economia e Sociologia Rural, v.31, n.4, p.291-308, 1993.

AGUIAR, D.R.D.; BARROS, G.S.A.C. Transmissão de preços da laranja entre mercados externo e interno. Revista de Economia e Sociologia Rural, v.37, n.1, p.61-70, 1989.

ASSUMPÇÃO, R.M.V.; JORDÃO, M.C.S. Qualidade da resina de coníferas. Silvicultura, v.8, n.33, p.14-22, 1983.

AUGUSTO FILHO, F. Resinas, em busca de alternativas. Silvicultura, v.15, n.53, p.16-28, jan./fev.1994.

AZEVEDO, P.F. Integração vertical e barganha. São Paulo, 1996. 219p. Tese (Doutorado) Faculdade de Economia e Administração, Universidade de São Paulo.

BAENA, E. de S. Análise da viabilidade econômica da resinagem e Pinus elliottii nas regiões do Sul do Estado do Paraná e Sul e Sudoeste do Estado de São Paulo. Curitiba, 1994. 87p. Tese (Doutorado) - Universidade Federal do Paraná.

BRITO, J.O.; BARRICHELO, L.E.G.; COUTO, H.T.Z.; CAPITANI, L.R.; NEVES, M.A. Método rápido para estimar a produção de resina em arvores de Pinus. Circular Técnica IPEF, v.148, p.1-9, ago. 1982. 
BRITO, J.O.; BARRICHELO, L.E.G.; TREVISAN, J.F. Condições climáticas e suas influências sobre a produção de resinas de pinheiros tropicais. IPEF, n.16, p.37-45, 1978.

BRITO, J.O. Diagnóstico sobre o setor de produção de resina de Pinus no estado de São Paulo. IPEF, abr. 1998. 7p. Suplemento. /Apresentado como Proposta de Pesquisa, Piracicaba, $1998 /$

BUENO, A.R. Abastecimento de madeira para produção de celulose: uma aplicação da economia de custos de transação. Piracicaba, 1998, 127p. Tese (Mestrado) - Escola Superior de Agricultura Luiz de Queiroz, Universidade de São Paulo.

CLEMENTS, R.W. Air temperature and gum yield. Washington: United States Department of Agriculture, 1961. p.1-2 . (Research note, 168)

CLEMENTS, R.W.; GURGEL, O.A. Métodos de moderna resinagem: manual. São Paulo: Instituto Florestal, 1970. 32p.

COSTA, F.G.; EXPEDITO, R.; SANCHES V.; FERREIRA, J.J. Seleção de alternativas para a obtenção de matéria-prima pela indústria resineira através de dominância estocástica. / Apresentado à disciplina Pesquisa Operacional da Escola Superior de Agricultura "Luiz de Queiroz”, Piracicaba, 1998/

DAVIS, J.H.; GOLBERG, R.A. A concept of agribusiness. Boston: Harvard University, 1957. $135 \mathrm{p}$.

FERNANDES, P.S.; OSORIO, R.G.S.; DESTEFANI, J.C.; STAPE, J.L. Efeito da concentração da pasta na produção de resina. Boletim Técnico do Instituto Florestal, v.40a, n.2, p.65665, dez.1986.

FERNANDES, P.S.; OSORIO, R.G.S.; DESTEFANI, J.C.; STAPE, J.L. Estudo do efeito da largura da painel na produção de resina. Boletim Técnico do Instituto Florestal, v.40a, n.2, p.666-72, dez.1986. 
FIGUEIREDO FILHO, A. Influência da resinagem no crescimento de Pinus elliottiii e sua avaliação econômica.Curitiba, 1991. 138p. Tese (Doutorado) - Universidade Federal do Paraná.

FIGUEIREDO, A.; MACHADO, S.A.; HOSOKAWA, R.T.; KIKUTI, P. Avaliação econômica da resinagem em florestas de Pinus elliottii engelm. Var. elliottii. IPEF, n.45, p.48-63, 1992.

FLORESTAR ESTATÍSTICO. São Paulo: Fundação Florestal, v.1-4, 1993-1996.

FONSECA, S. M. da; KAGEYAMA, P. Y. Melhoramento genético face a produção de resina. Circular Técnica do IPEF, v.36, 1978, 16p.

GARRIDO, M.A.O. et al. Resinagem: manual de resinagem. São Paulo: Instituto Florestal, Coordenadoria de Informações Técnicas, Documentação e Pesquisa Ambiental. Secretaria do Meio Ambiente. 1996, 33p.

GRANGER, C.W.J. Investigating causal relations by econometric models and cross-spectral methods. Econometrica, v.37, n.3, p.424-38, July 1969.

GRÔPPO, G.S. Análise do processo de transmissão do preço do café no período de 1987-1995, Revista Economia e Sociologia Rural, v.35, n.4, p.135-149, 1996.

GURGEL FILHO, O.A. Contribuição à resinagem. São Paulo: Coordenadoria da pesquisa dos recursos naturais. São Paulo: Instituto Florestal, 1972. 39p.

GURGEL, O.A.; FARIA, A.J.: Fatores que influem na resinagem de Pinus. Circular Técnica IPEF, v.37, p.1-20, maio 1978.

HODGES, A.W.; WILLIAMS, G. Pine gum in a bottle? Naval Stores Review. v.68, n.3. p.7-8, May/June 1993.

HOFFMAN, R. Estatística para economistas. 3. ed. São Paulo: Editora Pioneira, 1998. 430p. 
HOMA, M. Considerações técnicas e potencialidade da produção de derivados de resina de Pinus. Silvicultura, v.8, n.33, p. 61-66, 1983.

JANK, M.S. Competitividade no agribusiness brasileiro: discussão teórica e evidências no sistema carnes. São Paulo, 1996. 195p. Tese (Doutorado) - Faculdade de Economia e Administração, Universidade de São Paulo.

KOPPEN, J.; HONE G.A. Non-wood forest products 2. Rome: FAO, 1995. 109p. (FAO. Natural Resources Institute)

LEITE, A.; MORAIS, C.E. Produtos não lenhosos da floresta mediterrânea: situação atual do setor dos produtos resinosos em Portugal e suas perspectivas. DGF Informação, v.1, n.2, p.5-6, abr./jun. 1990.

MASTEN, S.E. Empirical research in transaction cost economics: challenges, progress, directions/ Presented in the Transaction Cost Economy and Beyond conference, Rotterdam, June. 1994.

NAVAL STORES REVIEW. International yearbook 1997. New Orleans, 1998. 26p.

NAVAL STORES REVIEW. Market Analysis 1997. New Orleans, 1998. 23p.

OLIVEIRA, J. G. Avaliação da produção de resina em progênies de Pinus elliottis em idade juvenil. Curitiba, 1987. 95p. Tese (Mestrado) - Universidade Federal do Paraná.

PORTUGAL. Ministério da indústria e energia. Análise tecnológica do setor dos produtos resinosos. Laboratório Nacional de Engenharia e Tecnologia. Lisboa: Secretariado Técnico do Estudo Tecnológico. 1984. 66p.

RIBAS, C.; ASSINI, J.L.; GURGEL GARRIDO, L.M.A. Resinagem de Pinus elliottii: efeito da quantidade de acido sulfúrico na produção de resina e na altura da face de resinagem. Boletim Técnico. Instituto Florestal. São Paulo, 1986. 8p. 
RIBAS, C.; GARRIDO, L.M.A.; GARRIDO, M.A.O.; ASSINI, J.L.; HAGA, N. Resinagem de Pinus caribaea Mor. Var. bahamensis. Silvicultura, v.8, n.28, p.851-6, 1983.

RINCOSKI. Efeito da resinagem nas características da madeira de pinus elliottii Engel. Curitiba, 1994. 112p. Tese (Mestrado) - Universidade Federal do Paraná.

SILVA, H. M. Resinagem de Pinus elliottii var densa e de Pinus oocarpa. Boletim Técnico. Instituto Florestal, v.38, n.2, p.177-85, ago./984.

SIMS, C.A. Money, income and causality. American Econometric Review, v.62, n.4, p.540520, Sep. 1972.

WILIAMSON, O.E. The mecanisms of governance: prologue. Berkeley: University of California, Nov. 1994. 33p.

WILIAMSON, O.E. Transaction cost economics and organization theory. Berkeley: University of California,1993. chap.2, p. 30-42: Industrial and Corporate Change.

ZYLBERSZTAJN, D. Estruturas de governança e coordenação do agribusiness: uma aplicação da nova economia das instituições. São Paulo, 1995. 238p. Tese (Livre Docência) Faculdade de Economia e Administração, Universidade de São Paulo. 